UNIVERSIDADE DE SÃO PAULO

FACULDADE DE FILOSOFIA, LETRAS E CIÊNCIAS HUMANAS DEPARTAMENTO DE LETRAS MODERNAS

IVAIR CARLOS CASTELAN

TRIESTE, INAPTIDÃO E CIÚME: TRÊS COMPONENTES FUNDANTES DO ROMANCE SVEVIANO

VERSÃO CORRIGIDA

SÃO PAULO 


\section{TRIESTE, INAPTIDÃO E CIÚME: TRÊS COMPONENTES FUNDANTES DO ROMANCE SVEVIANO}

\section{VERSÃO CORRIGIDA}

Tese apresentada ao Programa de PósGraduação em Língua, Literatura e Cultura Italianas do Departamento de Letras Modernas da Faculdade de Filosofia, Letras e Ciências Humanas da Universidade de São Paulo para obtenção do título de Doutor em Língua, Literatura e Cultura Italianas.

Área de Concentração: Língua, Literatura e Cultura Italianas.

Orientadora: Profa. Dra. Doris Nátia Cavallari

De acordo:
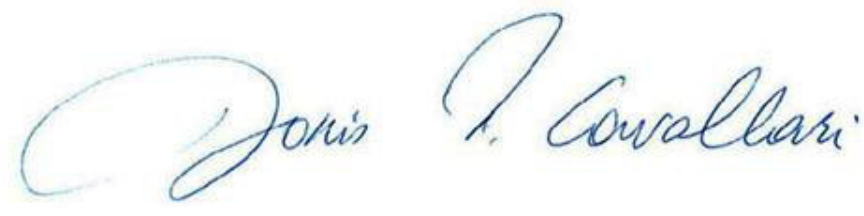

Profa. Dra. Doris Nátia Cavallari - Orientadora

São Paulo 


\section{FOLHA DE APROVAÇÃO}

Ivair Carlos Castelan

Título: Trieste, inaptidão e ciúme: três componentes fundantes do romance sveviano

Tese apresentada ao Programa de Pós-Graduação em Língua, Literatura e Cultura Italianas do Departamento de Letras Modernas da Faculdade de Filosofia, Letras e Ciências Humanas da Universidade de São Paulo para obtenção do título de Doutor em Língua, Literatura e Cultura Italianas.

Área de Concentração: Língua, Literatura e Cultura Italianas.

Aprovado em:

Banca Examinadora

Prof. Dr.:

Instituição:

Assinatura:

Prof. Dr.:

Instituição:

Assinatura:

Prof. Dr.:

Instituição:

Assinatura:

Prof. Dr.:

Instituição:

Assinatura:

Prof. Dr.:

Instituição: Assinatura: 
DEDICATÓRIA

A todos aqueles que, de algum modo, estiveram ao meu lado nesta longa e fascinante jornada. 


\section{AGRADECIMENTOS}

a Deus, pelas batalhas vencidas, pelas conquistas, pela concretização deste trabalho;

a toda minha família, pela confiança depositada;

à Profa. Dra. Doris Nátia Cavallari, pela paciente e sábia orientação;

à CAPES pela concessão de bolsa de estudos, no Brasil e na Itália, sem a qual talvez não teria conseguido concretizar este trabalho;

a toda a equipe do Departamento de Letras Modernas, em especial Edite e Júnior, sempre atenciosos e dispostos a esclarecer todas minhas dúvidas;

à Biblioteca da $\mathrm{FFLCH}$, pelo empréstimo de livros, e a todos os funcionários, pelo atendimento atencioso;

ao Prof. Guido Baldassarri, pelo acolhimento na Universidade de Padova e, pelas produtivas orientações;

à Profa. Sandra Bagno, da Universidade de Padova, pelo carinho, atenção e dicas valiosas para a concretização deste trabalho;

à Profa. Dra. Roberta Barni, pelas sugestões pertinentes durante o Exame Geral de Qualificação, pelo carinho e por acreditar em meu potencial;

à Profa. Dra. Adriana lozzi Klein, pelas sugestões pertinentes durante o Exame Geral de Qualificação, pela atenção e incentivos;

à Profa. Dra. Maria Gloria C. Mazzi, pelo carinho, atenção e por contribuir na concretização de minha ida à Itália;

à amiga especial, irmã, Adriana Duarte, pela constante presença e apoio incondicionais;

ao amigo, irmão, Claudemir F. Santos, pelos ensinamentos, pela companhia nos momentos de tensão e alegria;

à amiga atenciosa, Daniela Vieira, distante fisicamente, mas sempre presente espiritualmente e no coração;

à amiga Christie Paschoalino, pela tradução do abstract e pela incondicional amizade;

à médica e amiga Dra. Márcia Facco, pelo caráter, integridade e bondade, por acompanhar todo o meu trajeto, sempre confiante e segura de meu potencial;

enfim, a todos os meus amigos! 


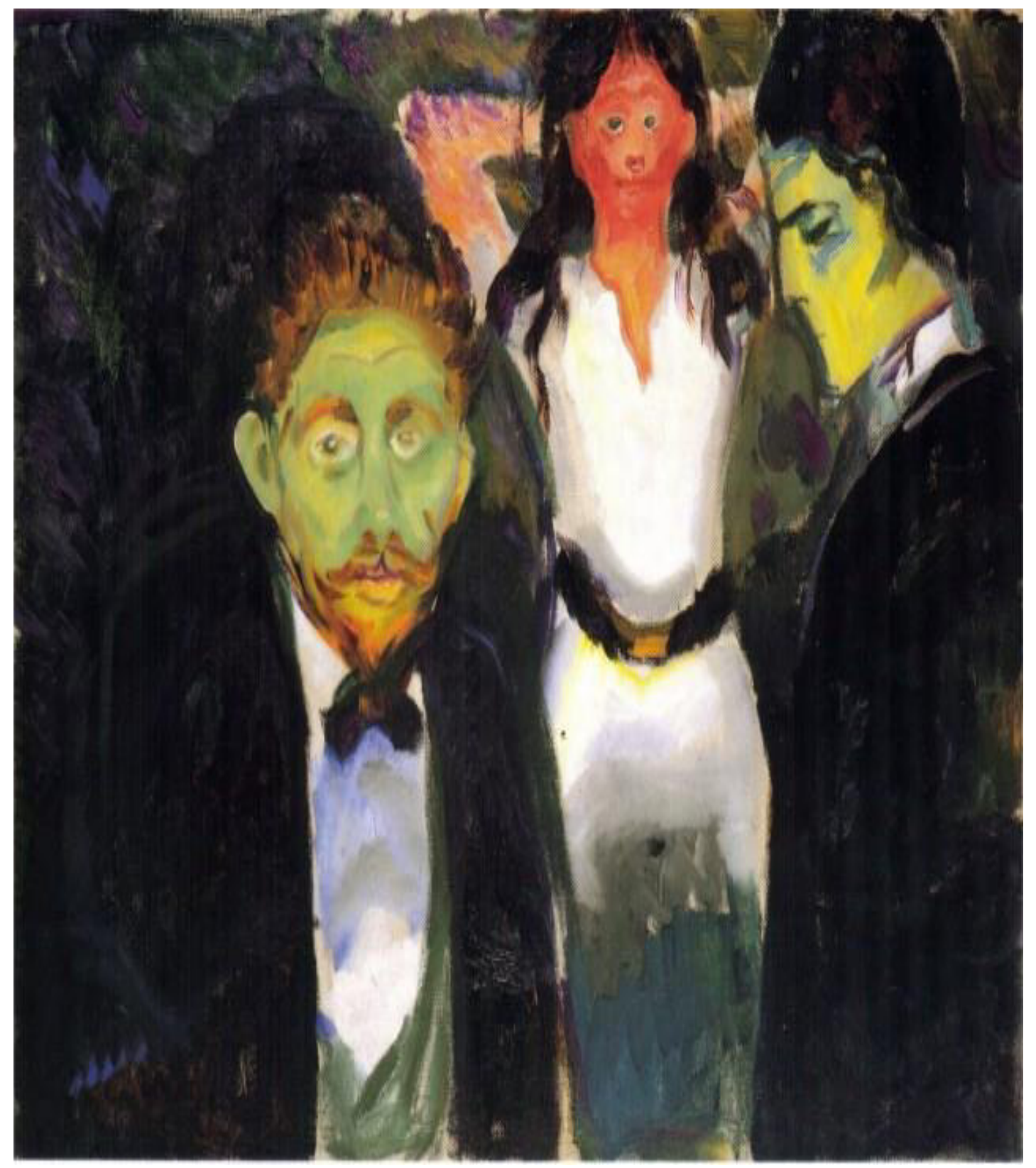

Jealousy. (1907) Edvard Munch

Acautele-se, meu senhor, contra o ciúme. É ele o monstro de olhos verdes que zomba da carne com que se alimenta.

W.Shakespeare (Otelo, cena III, ato III.) 


\section{RESUMO}

CASTELAN, I.C. Trieste, inaptidão e ciúme: três componentes fundantes do romance sveviano. 2014. 191 f. Tese (Doutorado) - Faculdade de Filosofia, Letras e Ciências Humanas, Universidade de São Paulo, São Paulo, 2014.

O principal objetivo deste trabalho é realizar uma leitura atenta que demonstre a importância do ciúme para a tessitura narrativa nos romances de Italo Svevo: Una vita (1892), Senilità (1898) e La coscienza di Zeno (1923). A partir da ordem de publicação de cada obra, pretende-se desvelar as relações amorosas, desnudando o modo como o ciúme apresenta-se nas histórias vividas pelos personagens. As diversas teorias que discorrem sobre o ciúme, ainda que de modos diferentes, convergem em um ponto, ou seja, no caráter triplo desse sentimento que terá, portanto, o triângulo como a forma geométrica que melhor o representa. Todavia, o ciúme será analisado neste estudo, sobretudo, à luz da teoria do filósofo francês, René Girard. Este trabalho ainda trata de duas questões fundamentais na obra de Svevo, intrinsicamente ligadas ao ciúme: o ambiente triestino, onde se desenrolam as histórias e o caráter inapto de seus protagonistas.

Palavras-chave: 1.Romance sveviano. 2. Ambiente triestino. 3. Ciúme. 4. Triângulo amoroso. 5. Inapto. 


\section{ABSTRACT}

CASTELAN, I.C. Trieste, inaptitude and jealousy: three foundational components of svevo's novels. 2014. $191 \mathrm{f}$. Thesis (Doctorate) - Faculdade de Filosofia, Letras e Ciências Humanas, Universidade de São Paulo, São Paulo, 2014.

The main goal of this work is to produce an attentive reading that demonstrates the importance of jealousy shaping the narrative web in Italo Svevo's novels: Una vita (1892), Senilità (1898) e La coscienza di Zeno (1923). Following the chronological order of each piece, the intent is to unveil the amorous relationships by uncovering the manner jealousy is presented in characters' histories. The diverse theories lecturing on jealousy -though may diverge in some aspects- end up converging in one: the triple aspect of the feeling, the triangle for its geometrical shape that very well represents it. However, jealousy will be taken in this study, most of all, enlightened by the french philosopher theory of René Girard. Furthermore, this thesis also deals with two important matters of Svevo's work, intrinsically linked to jealousy: the Triestian enviroment, where main characters' storyline and inaptitude flourish.

Keywords: 1. Svevian novels. 2. Triestian enviroment. 3. Jealousy. 4. Love triangle. 5. Inaptitude. 


\section{RIASSUNTO}

CASTELAN, I.C. Trieste, inettitudine e gelosia: tre elementi fondatori del romanzo sveviano. 2014. $191 \mathrm{f}$. Tesi (Dottorato) - Faculdade de Filosofia, Letras e Ciências Humanas, Universidade de São Paulo, São Paulo, 2014.

L'obiettivo principale di questo lavoro è quello di fare una lettura attenta che dimostri l'importanza della gelosia nella narrativa dei romanzi di Italo Svevo: Una vita (1892), Senilità (1898) e La coscienza di Zeno (1923). Dalla data di pubblicazione di ogni opera, si intende di svelare le relazioni amorose, scoprendo come la gelosia si presenta nelle storie vissute dai personaggi. Le diverse teorie che trattano sulla gelosia, anche se in modi diversi, convergono in un punto, cioè, il triplice carattere di questo sentimento che avrà dunque il triangolo come la forma geometrica che meglio lo rappresenta. Però, la gelosia sarà analizzata in questo studio, soprattutto, alla luce della teoria del filosofo francese René Girard. Questo lavoro discute anche due questioni essenziali nell'opera di Svevo, intrinsecamente legate alla gelosia: l'ambiente triestino, dove le storie si svolgono e i caratteri inetti dei suoi protagonisti.

Parole chiavi: 1. Romanzo sveviano. 2. Ambiente Triestino. 3. Gelosia. 4. Triangolo amoroso. 5. Inetto. 


\begin{tabular}{|l|r|}
\hline 1. Jealousy (1907) Edvard Munch & 6 \\
\hline 2. Trieste - Itália (visão panorâmica) & 21 \\
\hline 3. Biblioteca Civica di Trieste & 49 \\
\hline 4. II passeggio Sant'Andrea a Trieste (1898) \\
$\quad$ Giovanni Zangrando
\end{tabular}


Sumário

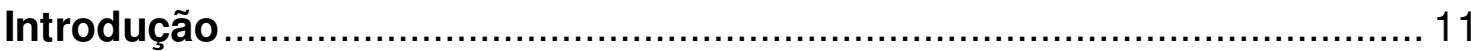

1. O ambiente triestino e a narrativa sveviana .................................. 20

1.1 Trieste e suas confluências ........................................................ 25

1.2 Una vita: uma Trieste burocrática em cena ................................. 29

1.3 Senilità: Trieste e seus ambientes exteriores............................. 40

1.4 La coscienza di Zeno: uma Trieste burguesa ............................... 51

2. Ciúme: as várias teorias que se interseccionam .......................... 62

2.1 Una vita: ciúmes e renúncia a uma paixão .....................................6 68

2.20 ciúme em Senilità: fio condutor da narrativa ............................ 87

2.3 La Coscienza di Zeno: ciúme e posse em cena ............................ 109

3. Personagem inetto em cena na obra sveviana: breve apresentação 133

3.1 Un inetto ou a representação de um sujeito comum? 136

3.2. II carnevale di Emilio ou a renúncia aos prazeres da vida? 146

3.3 La coscienza di Zeno e o inapto às avessas 167

Considerações Finais 176

Referências bilbiográficas 183 


\section{Introdução}

O ciúme vê com lentes, que fazem grandes as coisas pequenas, gigantes os anões, verdades as suspeitas.

Camilo Castelo Branco

Aaron Hector Schmitz, no ambiente familiar Ettore, nasceu em 19 de dezembro de 1861, em Trieste, nordeste da Itália, e morreu em 13 de setembro de 1928, na cidade de Motta di Livenza, província de Treviso, vítima de um acidente automobilístico.

O escritor optou por utilizar artisticamente um nom de plume, Italo Svevo, pseudônimo escolhido no intuito de homenagear sua dupla formação cultural: a italiana e a alemã.

Em sua arte, podemos apreender a confluência de várias correntes filosóficas e literárias. Svevo sempre se entregou à leitura dos grandes nomes da literatura, das ciências modernas e da filosofia, entre eles Schopenhauer, Darwin, Nietzsche, Freud, Tchecóv, Marx, Dostoevsky, além dos grandes romancistas franceses, como Zola. De acordo com Micaela Pretolani Claar, para entender e "emoldurar" o nascimento e o crescimento de sua obra literária, é necessário aproximá-lo dos grandes escritores europeus que influenciaram as novas formas da narrativa do século XX: Proust, Joyce, Musil e Kafka (CLAAR, 1986, pp.102-3).

De Schopenhauer, herdou não só o pessimismo, mas também a consciência de que a ambiguidade comportamental do homem não permite determiná-lo cientificamente. 
A leitura de Marx, cuja temática de integração social ultrapassou o nível político, ganhando valor existencial e universal, foi essencial na visão do escritor triestino sobre a crise vivida pela burguesia, a qual se identificava com a crise do homem moderno.

Através da teoria de Darwin, de acordo com Matteo Palumbo, Svevo extraiu uma característica determinante para sua obra, a representação de relações interpessoais como competitividade e luta. A propósito, seu primeiro conto, escrito em 1889, chama-se Una lotta. Como consequência dessa luta, teríamos a divisão de seus personagens em fracos e fortes, sãos e moribundos, inaptos e capazes, vitoriosos e derrotados (PALUMBO, 2007, pp.140-1).

Mundialmente conhecido e respeitado, Italo Svevo ${ }^{1}$ é considerado, hoje, um dos maiores romancistas do século $X X$, precursor de uma narrativa tida como de vanguarda. No Brasil, cada vez mais estudiosos, críticos e leitores veem em sua obra um universo riquíssimo a ser descoberto e explorado.

Desse modo, todas as citações e os trechos dos romances citados estão em português com o original transcrito em nota. Nosso intuito ao fazer tais escolhas deve-se, principalmente, à disponibilização de nosso trabalho não só aos apreciadores e conhecedores da língua italiana, mas também àquele leitor "curioso" que almeja aprofundar-se no reino da narrativa sveviana, em especial através dos romances que compõem nosso corpus de estudo.

\footnotetext{
${ }^{1}$ Atualmente, Svevo é considerado, segundo dados estatísticos publicados no suplemento literário Tuttolibri, do jornal La Stampa, de Turim, o mais importante escritor italiano do século XX. Em um plebiscito, realizado entre os leitores do jornal italiano, o romance $A$ consciência de Zeno, de Italo Svevo, foi escolhido com 3059 votos como o livro italiano mais importante do século passado. In: CASTRO, Silvio. Svevo, da incompreensão à consagração. O Estado de São Paulo, 15-09-1985, p.8.
} 
Seus três romances ${ }^{2}$ — Una vita (Uma vida), 1892, Senilità (Senilidade), 1898 e La coscienza di Zeno (A consciência di Zeno), 1928 - formam uma trilogia, na qual temos bem delineada e aprofundada a análise dos meandros do eu mais submerso do inconsciente. A tríade, de acordo com Teresa de Lauretis, propõe

o mesmo conteúdo de experiência humana: amor não correspondido, dialética empregado-patrão, doença, morte, temas que se organizam em torno e em relação ao Herói, refletindo assim a unicidade de uma experiência individual vista através de lentes diversas e projetadas caso a caso em diferentes esquemas. ${ }^{3}$ (LAURETIS, 1976, p.12, tradução nossa)

As três obras investigam a realidade do homem em um mundo que se apresenta em conflito com seus anseios e desejos. A representação dessa realidade, ainda atual para os dias de hoje, foi um dos motivos para enveredarmos pelos caminhos sinuosos da narrativa sveviana, buscando analisá-la e entendê-la, sobretudo, a partir das relações intersubjetivas vividas pelos seus verossímeis personagens, em especial, as relações afetivas, permeadas por um sentimento, que nos causou inquietação, instigando-nos a compreendê-lo melhor na tessitura dos três romances, ou seja, o ciúme.

\footnotetext{
${ }^{2}$ Para as citações traduzidas dos três romances consultaremos as seguintes edições, que serão devidamente discriminadas nas referências bibliográficas: SVEVO, I. Uma vida; tradução e notas de Aurora Fornoni Bernardini e Homero Freitas de Andrade. São Paulo: Nova Alexandria, 1993.; SVEVO, I. Senilidade; tradução de Ivo Barroso. Rio de Janeiro: Nova Fronteira, 1982.; SVEVO, I. A consciência de Zeno; tradução de Ivo Barroso. Rio de Janeiro: Nova Fronteira, 2006. No entanto, as referências aos respectivos títulos, no corpo do texto, serão feitas na versão original.

${ }^{3}$ lo stesso contenuto di esperienza umana: amore non corrisposto, dialettica servo-padrone, malattia, morte, temi che si organizzano attorno all'Eroe e in relazione ad esso, riflettendo così l'unicità di una singola esperienza vista attraverso lenti diverse e proiettata su schermi di volta in volta diversi. In LAURETIS, Teresa de. La sintassi del desiderio: Struttura e forme del romanzo sveviano. Ravenna : Longo Editore, 1976, p.12.
} 
Tal sentimento, sempre fez parte da vida pessoal do escritor ${ }^{4}$. Sua esposa Livia Veneziani Svevo, em Vita di mio marito, afirma que Svevo, talvez movido pela diferença de idade entre eles (Livia era 13 anos mais jovem que Italo), era atormentado por um forte ciúme, quase doentio (SVEVO, 1976, p.36).

Svevo serviu-se de suas experiências e observações pessoais, bem como de leituras diversas, entre elas da obra de Shakespeare, cujo ciúme aparece como tônica central em grande parte de seus escritos, imprimindo a eles um tom particular. O embrião do ciúme foi esboçado por ele já no conto Una lotta, publicado em três capítulos no jornal L'indipendente, em janeiro de 1888. Tal sentimento se fará presente em textos posteriores como nos três romances, Una vita (1892), Senilità (1898) e La coscienza di Zeno (1923), que servem de recorte para nossa análise e compreensão do ciúme em sua obra.

Há que se salientar que nosso interesse em investigar a presença do ciúme, na composição da narrativa sveviana, foi despertado, principalmente, a partir do segundo romance, Senilità, no qual tal sentimento apresenta-se de forma mais intensa, atuando, a nosso ver, como tônica central da narrativa. No entanto, após uma releitura, mais atenta e enviesada por tal questão, dos outros romances notamos a pertinência em seguir, etapa por etapa, a presença do ciúme nas histórias desses protagonistas.

A fim de iluminar as veredas percorridas, dividimos o presente trabalho em três capítulos. No primeiro, intitulado $O$ ambiente triestino e a narrativa sveviana,

\footnotetext{
${ }^{4}$ Importante ressaltar que não pretendemos fazer um estudo da presença do ciúme na narrativa sveviana a partir da vida pessoal do escritor. O caráter ciumento de Svevo, apontado por sua esposa em Vita di mio marito, foi destacado apenas como uma informação complementar.
} 
optamos por apresentar a sociedade triestina à época de Italo Svevo. Trieste, como pretendemos mostrar, além de ser uma grande inspiração para o escritor, atua como verdadeira protagonista nas histórias vividas pelos personagens.

De acordo com Bon, uma das principais e mais marcantes características dessa fascinante e múltipla cidade era o dinamismo consequente da presença de um porto que recebia navios de diversas nações, sendo "habitado" por uma verdadeira babel de línguas estrangeiras que se juntava ao triestino, dialeto local, ao italiano acadêmico das classes cultas e ao alemão (BON, 1977, p.5).

É nesse cenário cosmopolita, mitteleuropeu e prismático que Svevo ambientará seus romances. Em nossa "visitação" a Trieste, buscamos norteamento, sobretudo, nos estudos de Elio Apih (1988) e Claudio Magris (1988), para realizar um retrato do ambiente triestino e esboçar um pouco da história e particularidades dessa cidade.

Para o retrato da Trieste, esboçada em cada romance, utilizaremos da análise de Diego Marani (2003), em A Trieste con Svevo. Através desse estudo, pretendemos mostrar alguns detalhes sobre a caracterização do ambiente e sociedade triestinos em cada narrativa.

No segundo capítulo, intitulado Ciúme: as várias teorias que se interseccionam, apresentamos algumas teorias sobre o ciúme com o intuito de compreendê-lo melhor. Explicitaremos que esses estudos convergem em um ponto: no "caráter" triplo do ciúme, que sempre envolve três pessoas: o eu ciumento, o 
objeto de desejo, e o outro, que conforme a teoria de René Girard (2009), a qual usaremos para fundamentar o presente estudo, seria o rival ou mediador.

Optamos por nos concentrar na apresentação da teoria de Girard juntamente com a análise das obras, por isso julgamos importante fazer uma breve apresentação do crítico francês.

René Girard, estudioso francês radicado nos Estados Unidos é autor de mais de 15 livros e centenas de ensaios e artigos. Três livros marcam datas fundamentais do percurso intelectual do pensador francês. Em 1961, publicou seu primeiro livro, Mentira Romântica e Verdade Romanesca (nossa principal obra de referência do autor para este estudo), expondo os princípios da teoria do desejo mimético, sobretudo no mundo moderno. Tal livro produziu forte impacto nos estudos literários, devido a uma inovadora abordagem das relações humanas. Acerca do desejo mimético, o usaremos para explorar a questão do ciúme nos três romances.

Em 1972, publicou A Violência e o Sagrado, apresentando o mecanismo do bode expiatório, visto como uma nova chave para a compreensão da gênese da cultura humana. O livro obteve grande êxito, por isso, já no ano seguinte, a revista Esprit dedicou um número especial à sua obra. Desde então, o interesse pela sua ideologia não parou de crescer.

Em 1978, Girard publicou seu terceiro livro, Coisas Ocultas desde a Fundação do Mundo. A obra, rapidamente, alcançou ampla repercussão, ocupando a lista dos livros mais vendidos por vários meses, despertando ainda interesse do público não acadêmico. 
Os pilares da ideologia girardiana alicerçam-se, sobretudo, em sua teoria mimética ou imitativa. Para Girard (2009) sempre elegemos um modelo para nos inspirar e o mesmo ocorre com o desejo. Para o teórico francês, o desejo também é imitativo, e tende a aumentar se tenho ciência de que meu objeto de desejo é desejado por um outro.

O teórico francês observa que toda relação amorosa é triangular, sempre haverá um terceiro entre o sujeito-desejante e seu objeto de desejo. Esse terceiro, segundo o crítico, pode ser chamado de rival ou mediador, sendo que entre ele e o sujeito-desejante haverá dois tipos de mediação: a interna, quando há contato entre os dois e a externa, quando não há contato entre eles.

Assim, procuraremos mostrar nos três romances os diversos triângulos amorosos que se formam, bem como o tipo de mediação que há entre sujeitodesejante e rival. Além disso, evidenciaremos o ciúme sentido pelos protagonistas, buscando entender a razão de sua existência, que, apresenta forte ligação com o caráter inapto e inseguro dos protagonistas. Tal inaptidão e insegurança, somadas ao grande desejo de possessão das mulheres, corroboram com o despertar do ciúme desses protagonistas.

Em Una vita, Alfonso Nitti, a exemplo de um adolescente possessivo, demonstrará forte ciúme pela rica e burguesa Annetta Maller. Até a posse da jovem sempre existirá um rival entre Nitti e a moça. Após uma noite de amor, Alfonso parece perder-se e questionar o sentimento que nutrira pela senhorita Annetta, 
optando por abandoná-la. Contudo seus sentimentos conturbados e seu ciúme apenas terão fim com seu suicídio.

Já em Senilità, veremos que o ciúme atua como o fio condutor da narrativa e também, da relação obsessiva de Emilio Brentani por Angiolina Zarri. O ciúme será importante por dar "vida" e movimento à narração, conectando as diversas situações vivenciadas por Emilio.

Em La coscienza di Zeno, o ciúme aparece de forma mais fluida ainda que, em alguns momentos, o protagonista demonstre um caráter possessivo. As relações triangulares farão parte das irônicas situações vividas e, contadas por Zeno, que dedica, inclusive, um capítulo para contar suas aventuras extraconjugais.

Assim, pretendemos acompanhar a presença e a progressão de tal sentimento em cada etapa da vida dos protagonistas, buscando um ponto comum sem nos esquecer de apontar as divergências - que conecte o ciúme nos três romances.

Para concluir o estudo, decidimos percorrer no terceiro capítulo, intitulado, Personagem inetto em cena na obra sveviana: breve apresentação, a questão da inaptidão, que apresenta forte ligação à temática do ciúme. A compreensão da problemática sobre a inaptidão será fundamentada, sobretudo, a partir das análises de Camerino (1974) e Manacorda (1972).

Em Una vita, cujo título original deveria ser Un inetto, mostraremos que Alfonso Nitti não é tão inapto quanto fora definido pela crítica. Veremos que existe uma oscilação dessa inércia no caráter de Nitti. Reconhecemos nele seu caráter 
inapto, contudo pretendemos evidenciar, conforme Fusco (1984), que Svevo coloca em cena um leque de reações que fazem contrapeso com a fraqueza e a inércia de Alfonso. Assim, apontaremos os momentos em que parece haver uma oscilação na inaptidão e, o consequente sentimento de inferioridade desse protagonista.

Já em Senilità, Emilio Brentani demonstrará certa paralisação provocada por sua inaptidão, buscando refúgio em seu mundo ficcional. Mesmo após o término com Angiolina, Brentani se aprisionará em uma senilidade existencial, no vigor de seus 35 anos.

Em La coscienza di Zeno, a inaptidão se apresentará de forma mais leve e irônica. Zeno também é um inapto, mas talvez favorecido pela sorte, como destacou Debenedetti (1995), consegue lidar melhor com a vida ao fazer um bom matrimônio ou mesmo ao enriquecer em meio à guerra, para citar alguns exemplos. Assim, Zeno, a nosso ver, demonstra ser um inapto às avessas, ou seja, é um homem bem sucedido que "favorecido" pela maturidade e pela condição socioeconômica, aceita sua "doença", e, sobretudo se aceita como burguês e sabe tirar proveito disso.

A partir da estrutura apresentada acima, pretendemos apontar a importância do ciúme na narrativa sveviana, bem como tal sentimento se apresenta nas tramas vividas por esses protagonistas inseguros e inaptos, para então chegarmos, às considerações finais. 


\section{O ambiente triestino e a narrativa sveviana}

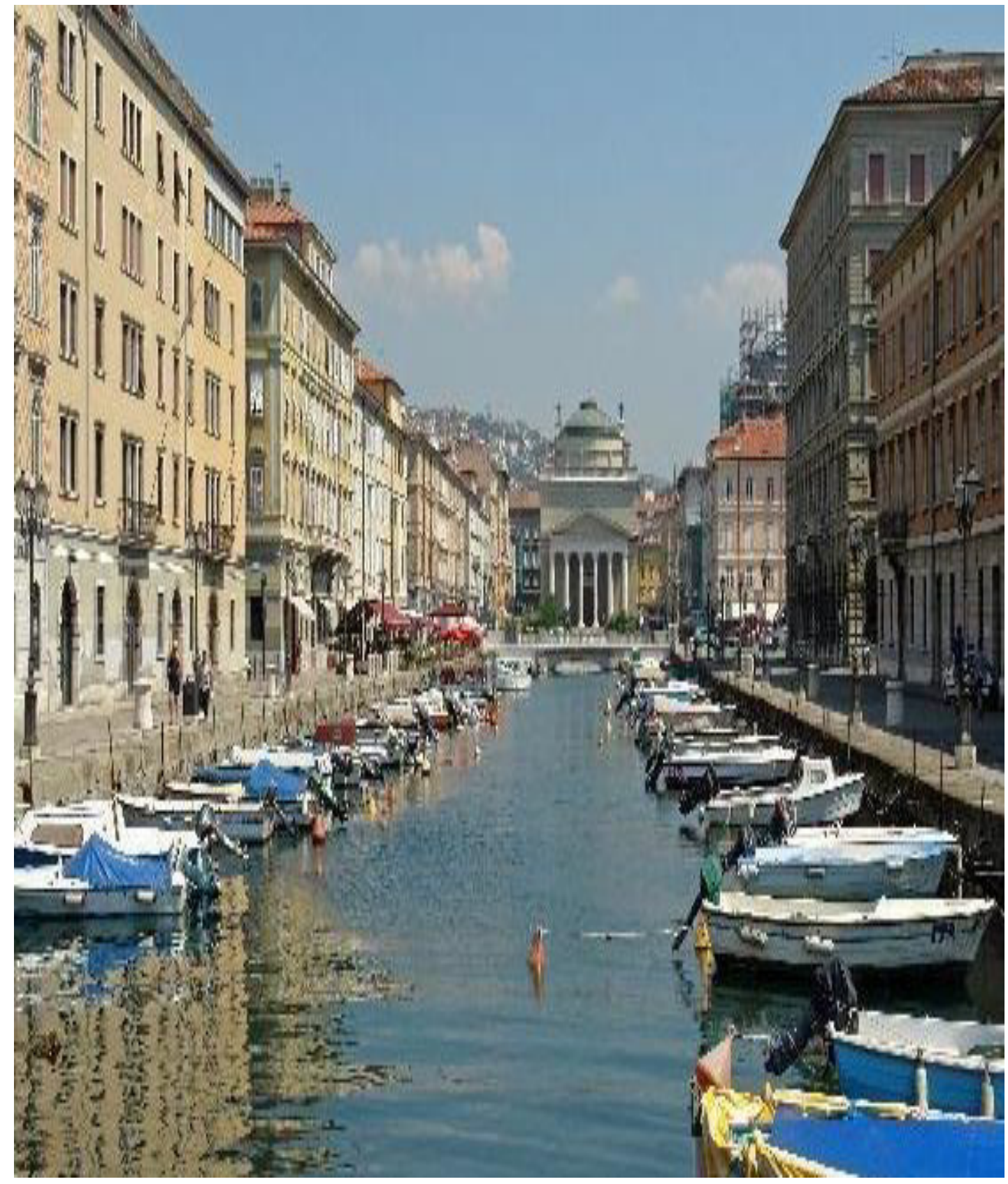

Trieste - Italia 
Embora não seja nosso objetivo fazer um estudo aprofundado sobre Trieste, a leitura dos romances de Svevo chamou nossa atenção para o ambiente da cidade em que se desenvolvem as tramas do autor. Desse modo, nosso olhar não pôde se furtar em perambular por essa bela e mitteleuropea cidade e, procurar entender sua importância para um de seus famosos concidadãos, o escritor Italo Svevo, e também a sua relação na constituição da narrativa sveviana. Assim, nosso intuito, ao visitar a história e as paisagens de Trieste, tal como apresentá-las aqui, é apenas de levar o leitor brasileiro a vislumbrar brevemente algumas, das muitas, particularidades da Trieste de Svevo.

A cidade situa-se ao nordeste da Itália, no mar Adriático, pertence à região Friuli-Venezia Giulia, faz fronteira com a Áustria e com a Eslovênia, sendo que já pertencera ao Império Austro-Húngaro, do qual era o principal porto. No século II a.C., a cidade tornou-se colônia romana com o nome de Tergeste, prosperando sob o domínio romano; com a queda do Império Romano do Ocidente, ficou sob o controle do Império Bizantino até 788 d.C., quando passou ao controle dos francos.

Somente no século XII a cidade tornou-se livre e, depois de séculos de batalhas contra a rival Veneza, em 1382 passou a pertencer ao Império Austríaco, tendo permanecido sob seu domínio até 1918.

Dentro da monarquia austríaca, Trieste ganhou grande importância enquanto cidade portuária, conservando autonomia administrativa até o século XVII. 
Em 1719, tornou-se porto franco, por decisão de Carlos IV de Ausburgo que visava ao aumento na exportação dos produtos do Império. Sendo a única saída pelo mar do Reinado Austríaco, Trieste foi objeto de grande investimento, desenvolvendo-se bastante, devido à sua condição privilegiada. Inicia-se, desse modo, a fortuna econômica dessa cidade aristocrática, que rapidamente torna-se palco da burguesia em ascensão.

Nessa época, o alemão era a língua oficial da cidade, muito usada pela burocracia local devido à importância das relações com a capital Viena. Ainda que o idioma italiano também fosse oficial, a população usava coloquialmente o dialeto triestino (que no curso do século XVIII substituiu o antigo dialeto friulano e tergestino).

A partir do século XIX, Trieste passou a ser reivindicada pelo movimento irredentista italiano, um grupo político que buscava a anexação à Itália de todas as terras habitadas por populações de língua italiana.

Em 1914, com o início da Primeira Guerra Mundial, a cidade constituiuse em um importante posto militar austríaco. Inicialmente aliada ao Império Austro-húngaro e ao Reino da Prússia, em 1915 o Reino da Itália rompeu com o pacto de aliança (após o acordo de Londres) e seguiu em direção às terras "italianas" do Império Austro-húngaro, procurando invadi-las rapidamente.

Com as ofensivas italianas e inglesas na região e com o fim da guerra, em 1918, o Reino da Itália ocupou as províncias meridionais do Império Austrohúngaro e imediatamente deu início a um processo de nacionalização (italianização), com tentativas de absorção cultural das minorias linguísticas 
pela parte italiana. Nascia assim o chamado "Fascismo de fronteira", precursor daquilo que seria depois o fascismo em nível nacional.

Com a entrada da Itália na Segunda Guerra Mundial, vários soldados de Trieste serviram no mar Adriático e no continente. A cidade portuária tornou-se estratégica e era visada, inclusive, pelo Reich alemão, por conta do prestígio alcançado antes de 1918.

No período que vai do armistício (8 de setembro de 1943) ao imediato pós-guerra, Trieste foi o centro de uma série de vinganças que marcaram profundamente a história da cidade e da região circundante. Durante a ocupação nazista, a Risiera di San Sabba - hoje Monumento Nacional - foi utilizada como campo de prisioneiros e também, de detenção e eliminação dos chamados partigiani italianos e eslavos, dissidentes políticos e judeus.

A Risiera foi o único campo de concentração na Itália e na Europa Meridional, munido de forno crematório, posto em funcionamento em 4 de abril de 1944.

As reivindicações iugoslavas e italianas, bem como a importância do porto de Trieste para os Aliados, foram o motivo, em 1947 sob a égide da ONU, da instituição do "Território Livre de Trieste" (TLT). Pela impossibilidade de nomear um Governador escolhido em acordo entre anglo-americanos e soviéticos, o TLT permaneceu dividido em duas zonas de ocupação militar: a Zona A, administrada pelos Aliados e, a Zona B, administrada pelos iugoslavos. Tal conjuntura perdurou até 1954, quando o problema foi resolvido com a divisão do território livre de Trieste segundo as duas zonas já designadas; 
assim, a lugoslávia chegava até os montes da periferia da cidade. Essa situação provisória foi resolvida somente em 1975, com o Tratado de Osimo entre a Itália e a então República Socialista Federal da lugoslávia, que finalmente tornava Trieste cidade italiana, mas garantia o acesso livre do porto à lugoslávia. 


\subsection{Trieste e suas confluências}

Se Trieste é um território de fronteira entre muitas tradições culturais, um de seus mais ilustres cidadãos, Italo Svevo, talvez seja o maior exemplo desse "caldeirão de etnias": nascido no seio de uma família com origens italianas, hebreias e alemãs, Aaron Hector Schmitz já traz no nome toda a herança multicultural desse território. De acordo com Elio Apih, a época do nascimento (1861), bem como da morte de Svevo (1928) incorrem exatamente com o advento e com a dissociação das instituições liberais de sua Trieste que, inicialmente, vive sob o domínio austríaco, sendo tardiamente anexada ao território italiano. (APIH, 1988, p.11).

Não é tão simples delinear os acontecimentos e as estruturas dessa sociedade, em especial aquela dos anos de Svevo, uma vez que, conforme Apih, há certa carência nos estudos da Trieste da época sveviana (APIH, 1988, P.11). Para Spagnoletti, tal cidade assemelha-se a "uma 'caldeira' na qual se misturavam e se debatiam, ou viviam com desconfiança, eslavos, alemães, italianos e exilados políticos de toda parte da Europa"5 (SPAGNOLETTI, 1991, p.9, tradução nossa).

Entre o final do século XIX e início do século XX a sociedade triestina é marcada por importantes desenvolvimentos. A Europa das grandes potências adentrava em uma fase caracterizada por sua máxima expansão, a mesma que seria determinante na geração dos contrastes que, por sua vez, desencadeariam a primeira guerra mundial. A Áustria, superadas as crises

\footnotetext{
${ }^{5}$ un crogiuolo dove si incrociavano e si contrastavano, o vivevano con sospetto, slavi, tedeschi, italiani e fuoriusciti di ogni parte d'Europa. In: SPAGNOLETTI, Giacinto. Svevo: da "Una vita" a "La coscienza di Zeno". Modena: Mucchi editore, 1991, p.9.
} 
internas, acompanhava esse processo que beneficiou amplamente 0 desenvolvimento de Trieste. Entre os anos de 1900 e 1910 sua população total passou de 176 a 235 mil habitantes, dos quais $5 \%$ eram alemães e judeus. A cidade despontou como um dos grandes centros mundiais da construção naval, da navegação a vapor, de empresas de seguros e do comércio do café. Nesse período foi iniciada a construção de outro porto, o terceiro na história da cidade (APIH, 1988, p.25).

Italo Svevo, de acordo com Apih, pertence a um mundo liberal: a sua obra é "discurso" (no sentido de diálogo e monólogo), relação crítica e dialética com o mundo interior e exterior. Ele é testemunha da orientação política da sociedade liberal-nacional italiana de Trieste (APIH, 1988, p.29).

A grande literatura mitteleuropea é principalmente crítica do eu, da tradição estoico-burguesa. Isso é também um dos grandes temas de toda a narrativa sveviana, ou seja, a união da crise do signo linguístico (cuja palavra enrijece e "mata" a vida) com a crise da individualidade psicológica. Inicia-se consequentemente a história de um grande tema da literatura contemporânea, ou seja, "o da insuficiência da palavra e da nostalgia de um léxico potencialmente infinito"6 (MAGRIS, 1988, p.50, tradução nossa).

Assim como a história de Trieste é feita de tantos acontecimentos, a narrativa do escritor triestino também é feita de muitas histórias que se mesclam, se fundem, dando origem a novas histórias que desafiam o leitor a

\footnotetext{
${ }^{6}$ quello dell'insufficienza della parola e della nostalgia di un lessico potenzialmente infinito. MAGRIS, Claudio. Svevo e la cultura tedesca a Trieste. In PETRONIO, Giuseppe. II caso Svevo. Palermo: Palumbo, 1988, p.50.
} 
decifrá-las, a preencher suas lacunas (ANZELLOTTI, 1985, p.9). Histórias que não poderiam deixar de lado essa tão instigante e multifacetária cidade, que servirá de inspiração, modelo para as narrativas de seu célebre habitante, Italo Svevo. 


\subsection{Una vita: uma Trieste burocrática em cena}

Na carta que abre a narrativa de Una Vita, temos a primeira impressão de Alfonso Nitti sobre Trieste, caracterizada de maneira pejorativa, já que o "ar é denso, carregado da fumaça, (...) pesado, em forma de um cone

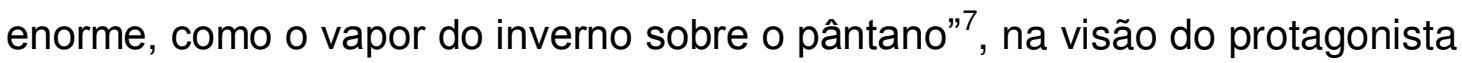
no dia de sua chegada à cidade (SVEVO, 1993, p.14). O olhar de Nitti sobre a cidade não poderia ser outro, uma vez que ele almeja retornar ao campo, e à convivência segura e protetora de sua mãe. Desse modo, Alfonso faz uma descrição da cidade opressora, do ambiente que esmaga o homem que se sente impotente para tomar as rédeas de sua vida. Trieste, poderíamos dizer, configura-se como o "rito de passagem" ao jovem que precisa assumir sua vida e tornar-se independente da mãe.

Una vita, iniciado em 1887 e publicado em 1892, é o romance de estreia de Italo Svevo. Originalmente intitulado "Un inetto" pelo escritor triestino, o livro teve seu título recusado pelo editor Treves, sendo publicado, a seguir, com todas as despesas pagas pelo escritor junto à editora Vram, com o título conhecido hoje.

O romance narra a história de Alfonso Nitti, que deixa a vida bucólica e tranquila do campo para trabalhar no banco Maller, com sede em Trieste. $O$ jovem de 22 anos tem certa cultura humanística; é um intelectual que divaga em suas reflexões e fantasias.

\footnotetext{
7 aria densa, affumicata, (...) greve, in forma di un enorme cono, come sul nostro stagno il vapore d'inverno. In SVEVO, Italo. Romanzi e "continuazioni”. Milano: Mondadori, 2006, p.6.
} 
$\mathrm{Na}$ cidade aluga um simples quarto na casa da decadente família Lanucci, cuja matriarca insistirá em unir, sem êxito, Alfonso e sua filha Lucia. A monotonia de sua existência começa a ser rompida quando o jovem, ao ser introduzido na casa de seu patrão, conhece a senhorita Annetta Maller, que inicialmente lhe é indiferente, e o primo da moça, o advogado Macario.

Alfonso, por sugestão do advogado quarentão, que conhece os dotes intelectuais e literários de Nitti, é convidado a participar das chamadas noites literárias, organizada pela senhorita Maller, que almeja escrever um romance, contudo não consegue colocar em prática mais um de seus caprichos. Ela, então, vislumbra em Alfonso um "instrumento" para concretizar seu desejo. Assim os dois iniciam a escrita de tal romance a quatro mãos. O que Nitti escreve é ignorado e a jovem burguesa refaz o que fora esboçado por ele.

Desse contato mais próximo, Alfonso, incialmente, demonstrará estar apaixonado por Annetta, que após relutar à corte do empregado de seu pai, cederá à tentação e se entregará a ele. Após uma noite de amor, a jovem pede ao "amante" que se afaste um tempo da cidade, pois ela precisa convencer seu pai a aceitá-lo no seio da família. Nitti aceita a imposição da moça e volta à sua antiga casa no campo. Contudo, a doença de sua mãe fará com que ele se ausente por um longo período do convívio com Annetta e isso será decisivo para que ela fique noiva do primo, o advogado Macario.

O retorno à cidade é doloroso a Alfonso, não apenas pela morte da mãe ou pela perda da amante, mas principalmente por não ter coragem e forças para enfrentar essa paixão e mudar sua existência miserável. No banco ele é 
transferido para um setor inferior, cuja remuneração é ainda mais baixa. Insatisfeito e desesperado, perde o controle da situação e enfrenta o patrão, o senhor Maller. Alfonso demonstra certa dificuldade em lidar com a questão do inesperado, situações como: a doença e morte da mãe, e o rebaixamento no banco que, aliás, o faz reagir, evidenciam essa relutância em enfrentar aquilo que não estava em seus planos.

Angustiado e aflito decide escrever a Annetta propondo um encontro, contudo a moça mandará em seu lugar o arrogante irmão, que o desafiará a um duelo para o dia seguinte. Sem coragem e força para enfrentar tal situação opta por um ato extremo: o suicídio.

Esta primeira narrativa de Svevo constitui-se em um bom exemplo do romance do século XIX, no qual temos em cena o embate do herói contra o mundo. Podemos dizer, com G. Lukács que "o romance é a epopeia de uma era para a qual a totalidade extensiva da vida não é mais dada de modo evidente, para a qual a imanência do sentido à vida tornou-se problemática" (LUKÁCS, 2002, p.55). Tal problematicidade da vida, característica do romance moderno, conforme o filósofo húngaro, é retratada por Svevo: seus protagonistas são apresentados em meio a uma existência conturbada, sendo incapazes de moldarem-se aos ambientes em que vivem, ou identificarem-se com ele, mas especialmente, são marcados pela inabilidade de acompanhar as mudanças de tais espaços.

Para Alberto Abruzzese, o ambiente delineado neste primeiro romance é aquele tipicamente triestino do banco. Todos os sentimentos, fatos e 
acontecimentos, narrados na obra, são descritos segundo a lógica "bancária", ou seja, por um viés totalmente técnico; o suicídio de Alfonso, por exemplo, é relatado em termos burocráticos na carta que encerra a narrativa (ABRUZZESE, 1979, p.18). A história de Alfonso, sem dúvida, se concentrará no banco Maller, do qual ele é funcionário, bem como na casa de seu patrão; ambientes burgueses, que implicam nas relações entre superiores e subalternos. O local de trabalho de Nitti é assim descrito:

Alfonso saiu do escritório bocejando. Um pequeno corredor escuro e estreito unia a sala ao corredor principal, onde se enfileiravam as portas todas iguais dos escritórios ainda iluminados, com os batentes pretos e os vidros embaçados. As portas das salas do senhor Maller e senhor Cellani, o procurador, traziam os nomes em preto sobre uma placa dourada. Em sua luz uniforme, as paredes imitando mármore, as placas das portas iluminadas mais forte, assim, sem penumbras, o corredor deserto parecia um daqueles quadros feitos para estudar a perspectiva, complicados mas só com luzes e linhas. ${ }^{8}$ (SVEVO, 1993, p.18, grifo nosso)

Note-se que a descrição alicerça-se no jogo entre o claro e o escuro. 0 corredor das salas dos funcionários, "inferiores" na hierarquia do banco é escuro e estreito; as salas são todas iguais com batentes também escuros e os vidros embaçados. Em contraposição, a sala do dono do banco e a do procurador demonstram grande ostentação, a começar pela placa dourada com os respectivos nomes escritos em preto, uma clara alusão ao ouro, à riqueza,

\footnotetext{
${ }^{8}$ Alfonso s'incamminò sbadigliando. Un piccolo corridoio angusto e oscuro univa la stanza al corridoio principale ai cui lati c'erano gli uffici, tutti ancora illuminati, dalle porte eguali, con le cornici nere e le lastre appanate. Quelle delle stanze del signor Maller e del signor Cellani, il procuratore, portavano i nomi in nero sopra una piastra dorata. Nella luce uguale, le pareti pitturate a imitazione di marmo, le lastre delle porte illuminate più fortemente, così, senza penombre, il corridoio deserto sembrava uno di quei quadri fatti a studio di prospettiva, complicati, ma solo di luce e di linee. In SVEVO, Italo. Romanzi e "continuazioni". Milano: Mondadori, 2006, pp.11-12.
} 
ao mundo mercantil e capitalista. A iluminação é clara, uniforme, sem penumbras e, para finalizar a caracterização, o corredor deserto se assemelha a uma obra de arte, isto é, produto de estudo de perspectiva e ilusão de ótica, avanço da ciência e, aqui, retrocesso da humanidade.

É essa a Trieste vista por Nitti, uma cidade rica e apática, em que a expansão capitalista inibe a expressão humana. Sua frieza se traduz nos batentes e salas escuros que reduzem o ser humano à força produtiva e contrastam com os nomes importantes e reluzentes. Tudo é refratário à dor, aos desejos e anseios, tudo é, para Nitti, desumano.

De acordo com Diego Marani, o banco onde Alfonso Nitti trabalha pode ser classificado como "o lugar do medo" por excelência, uma vez que é um ambiente povoado por personagens lúgubres como 0 chefe da correspondência Sanneo ou pelo procurador Cellani (MARANI, 2003, p.28).

Livia Veneziani Svevo, esposa de Svevo, em Vita di mio marito, afirma que a experiência do marido no Banco Union de Viena, ambiente tão amorfo, permitiu ao escritor reproduzir tal atmosfera em seu primeiro romance, Una vita, narrativa em que são delineadas várias características da burguesia mercantil triestina (SVEVO, 1976, pp.19-20). Boa parte da narrativa concentra-se nas atividades e relações vividas pelos personagens dentro desse ambiente de trabalho, marcado pela indiferença e competição nas relações, pela linguagem burocrática, pela repetição e pelo mal-estar dos subalternos: 
Cansaço? Estava mais para náusea. Lentamente, dia após dia, seu trabalho aumentava, mas em termos de qualidade pouco ou nada mudava. Durante toda a jornada, limitava-se à construção de um ou dois períodos, enquanto era obrigado a copiar inúmeras cifras, repetir inúmeras vezes a mesma frase. Quase ao fim do expediente, a mão, a única parte de seu corpo verdadeiramente cansada, parava sozinha, a atenção não estimulada distraía-se e, às vezes, precisava largar a pena e parar de trabalhar, por sentir aquela espécie de náusea própria de uma pessoa que abusou de um único alimento. Nunca estava em dia com suas tarefas e a seu malestar acrescentava-se a preocupação. ${ }^{9}$ (SVEVO, 1993, pp.6566 , grifo nosso)

Tal caracterização reproduz a insatisfação que o ambiente profissional representa dentro da história do protagonista. Parte integrante e essencial da narrativa sveviana, o ambiente configura-se de modo hostil a seus personagens, em especial aos protagonistas, típicos inaptos, que diante dessa hostilidade gerada pelo espaço habitado, se sentirão ainda mais inseguros e amedrontados, e consequentemente mais vulneráveis a se agarrarem a outros personagens, daí a possessão "doentia" e o ciúme que demonstram sentir.

Nesse sentido, recorremos mais uma vez a Lukács, para quem o romance moderno coloca em cena um herói problemático cuja interioridade "nasce da dualidade antagônica entre alma e mundo" (LUKÁCS, 2002, p.90). A incapacidade desse homem em enxergar-se como parte de seu mundo, é a mesma vivida por Alfonso, Emilio e Zeno. Para Debenedetti, esse homem não consegue se identificar com seu mundo, pois "a trégua entre ele e a sociedade,

\footnotetext{
${ }^{9}$ Stanchezza? Somigliava meglio a nausea. Lentamente il suo lavoro di giorno in giorno aumentava, ma in qualità di poco o nulla mutava. In un'intiera giornata egli aveva da costruire uno o due periodi; aveva invece da copiare innumerevoli cifre, ripetere innumerevoli volte la medesima frase. Verso sera la mano, l'unica parte del suo corpo veramente stanca, si fermava, l'attenzione non stimolata si distraeva e qualche volta doveva gettare la penna e lasciare il lavoro, per una nausea da persona che ha preso di troppo di un solo cibo. Non era mai a giorno con i suoi lavori e al suo malessere si aggiungeva l'inquietudine. Ibid., pp. 67-68.
} 
entre ele e o mundo, partiu-se" ${ }^{\prime 10}$ (DEBENEDETTI, 1987, p.515, tradução nossa). Diante dessa cisão entre o eu e seu ambiente social, o personagem sveviano sente-se excluído e fracassado, sem forças para enfrentar a própria inaptidão. A postura dos críticos reitera o pressuposto de que o ambiente social contribui com o acréscimo do sentimento de insegurança e medo vivenciado por esses personagens, reforçando, como já foi ressaltado, seus caráteres inseguros, possessivos, ciumentos.

Para Alfonso o emprego no banco é um martírio, pois está muito distante de sua grande paixão, a fantasia e o fictício, sem espaço nessa sociedade burguesa capitalista que visa à produção em série e sempre em maiores quantidades. A arte neste contexto aparece como decoração e, de certo modo, afirmação do status social e do poder aquisitivo:

Um grande número de fotografias dispostas em forma de leque aberto encontrava-se na parede acima do piano; os quadros, quatro ou cinco, pendiam altos demais e isso para deixar espaço para os encostos dos móveis.

Alfonso não entendia de pintura, mas havia lido alguns livros de história da arte, tinha alguma ideia do que significava a escola moderna. Ficou impressionado diante de um quadro que nada mais representava além de uma longa vereda, apenas esboçada por entre um chão de cascalhos. Não havia figura alguma; pedras, pedras, pedras. A cor era fria e o caminho parecia perder-se no horizonte. Uma desoladora falta de vida. ${ }^{11}$ (SVEVO, 1993, p.36, grifo nosso)

\footnotetext{
${ }^{10}$ perché è rotta la tregua tra lui e la società, tra lui e il mondo. In DEBENEDETTI, Giacomo. /I romanzo del novecento. Milano: Garzanti, 1987, p. 515.

${ }^{11}$ Un grande numero di fotografie era disposto in forma di ventaglio aperto sulla parete al di sopra del pianino; i quadri, quattro o cinque, erano appesi troppo in alto, e ciò per lasciar posto agli alti schienali dei mobili. / Non s'intendeva affatto di pittura Alfonso, ma aveva letto qualche volume di critica artistica e sapeva cosa significasse, nell'idea, scuola moderna. Rimase colpito dinanzi a un quadro che non rappresentava altro che una lunga via appena segnata attraverso terreno sassoso. Non v'era alcuna figura; sassi, sassi e sassi. II colore era freddo e la via sembrava perdersi all'orizzonte. Una mancanza di vita sconsolante. In SVEVO, Italo. Romanzi e "continuazioni". Milano: Mondadori, 2006, p. 33.
} 
Note-se que existe um grande número de quadros na parede da casa do patrão de Alfonso Nitti, o senhor Maller, o que aponta certa ostentação, imprimindo ao ambiente um tom desarmônico, em função da quantidade excessiva de obras pictóricas. Tais obras de arte parecem substituir a vida que foi "artificializada", endurecida como os mármores dos edifícios, além disso, a própria natureza representada parece morta, sem vida para o bucólico Nitti, que afinal é um homem do campo. Essa frieza e falta de vida, impressas no quadro, que chama atenção de Alfonso, na verdade refletem o espaço burguês também frio e sem vida. A biblioteca da mansão também o impressiona pela quantidade de livros:

Ficou surpreso que a biblioteca ficasse no quarto contiguo. Grandes estantes repletas de livros preenchiam quase inteiramente as paredes. O mobiliário era simples: uma mesa grande coberta por um pano verde no centro e em volta dela algumas cadeiras cômodas e dois sofás. ${ }^{12}$ (SVEVO, 1993, p.34, grifo nosso)

O cenário mostra uma classe social em ascensão, que parece querer mostrar um gosto refinado através da quantidade de arte nas paredes e de livros nas prateleiras, contudo parecem exemplos vazios, pois o grande número de livros não comprova sabedoria nem conhecimento ou cultura. Mais uma vez os livros atuam no ambiente meramente como peças decorativas, novamente em excesso, para comprovar o poder de consumo dentro do sistema capitalista. Não por acaso, será na biblioteca que a maioria das cenas se desenvolverá, esse cômodo da casa será o lugar de recepção das visitas. O

\footnotetext{
${ }^{12}$ Si sorprese di trovare nell'altra stanza la biblioteca. Grandi armadî contenenti libri coprivano quasi per intero le pareti. La suppellettile ne era semplice: un grande tavolo coperto da un panno verde nel mezzo e d'intorno delle sedie comode e due ottomane. Ibid., p. 31.
} 
luxo que impressiona e intimida Alfonso encontra-se também na sala de jantar, ambiente propício a receber os convidados:

Ficara intimidado com o luxo que vira e já não pensava mais naquele comportamento espirituoso que teria. Desejava estar fora disso e o que sentia não era nada agradável. Naquela casa cabia-lhe portar-se com modéstia, como subordinado que era. Um olhar um pouco mais habituado teria notado naquela decoração algo de excessivo, mas era a primeira vez que Alfonso via aquela riqueza toda e se deixava ofuscar. ${ }^{13}$ (SVEVO, 1993, p.35, grifo nosso)

Note-se que a ostentação do ambiente inibe o protagonista e corrobora com o seu papel nessa sociedade burguesa, o de subordinado. A riqueza ofusca a visão de Nitti, contudo o olhar mais apurado do narrador percebe que a decoração peca pelo exagero. Embora nosso estudo não se foque na questão da voz narrativa, vale ressaltar que aqui se percebem claramente duas vozes diferentes: a do narrador que produz comentários e a do protagonista que sente, que se emociona. Neste momento, o narrador se coloca como alguém, que ao contrário de Nitti, conhece tal mundo e sabe decodificá-lo. Através de comentários desse tipo, o narrador vai tecendo o retrato de um rapaz oprimido cuja única saída será o suicídio.

Nessas descrições da casa Maller, há um apelo e uma reiteração do poder de compra conquistado por tal classe social, que procura se impor pela ostentação e pelos excessos. Assim, dois mundos, ou melhor, duas realidades

\footnotetext{
${ }^{13}$ Era intimidito dalle ricchezze vedute e non sognava più il contegno da persona spiritosa. Desiderava di esserne fuori, ed era poco piacevole il suo sentimento. In quella casa bisognava contenersi modestamente, da subalterno. Un occhio più esercitato avrebbe scorto in quell'addobbo qualche cosa di eccessivo, ma era la prima volta che Alfonso vedeva di tali ricchezze e si lasciava abbagliare. Ibid., p. 32.
} 
se contrapõem, a dos patrões, detentores do capital, e a dos funcionários, subordinados que recebem um mísero salário insuficiente para um padrão de vida mais digno. A crítica quanto ao consumo desmedido é evidente, sendo que o dinheiro não compra o conhecimento e muito menos a sabedoria, que Alfonso demonstra possuir:

\begin{abstract}
Descobriu a biblioteca pública e aqueles séculos de cultura à sua disposição permitiram-lhe poupar seu magro provento. $\mathrm{O}$ horário fixo da biblioteca mantinha-o preso, conferia a seus estudos a regularidade que ele desejava. Frequentava assiduamente, até porque seu quarto na casa dos Lanucci era pouco propício aos estudos. Pequeno, com a cama ocupando metade da peça, quase não apanhava sol e era desagradável, sem falar da mesinha redonda de quatro pés que nunca tocavam o chão ao mesmo tempo, sentado à qual se tornava difícil pensar. ${ }^{14}$ (SVEVO, 1993, p.68)
\end{abstract}

Fundada em 1793, a Biblioteca Municipal de Trieste é importante por preservar as memórias históricas da cidade. Hoje, ela possui um amplo acervo com mais de 450.000 volumes, além de manuscritos, cartas e correspondências epistolares, manuscritos de música, gravuras, desenhos, mapas, fotografias e cartazes, e um grande arquivo com documentos do período que compreende de 1300 a 1800.

\footnotetext{
${ }^{14}$ Scoperse la biblioteca civica e quei secoli di cultura messi a sua disposizione, gli permisero di risparmiare il suo magro borsellino. Con le sue ore fisse, la biblioteca lo legava, apportava nei suoi studii la regolarità ch'egli desiderava. La frequentava assiduamente anche perché la sua stanza in casa Lanucci era poco adatta a studiarci. Piccola, a mezzo occupata dal letto, di rado visitata dal sole, era disaggradevole e non era facile pensare su un tavolinetto rotondo di cui le quattro gambe non toccavano mai contemporaneamente il pavimento. Ibid., pp. 70-71.
} 


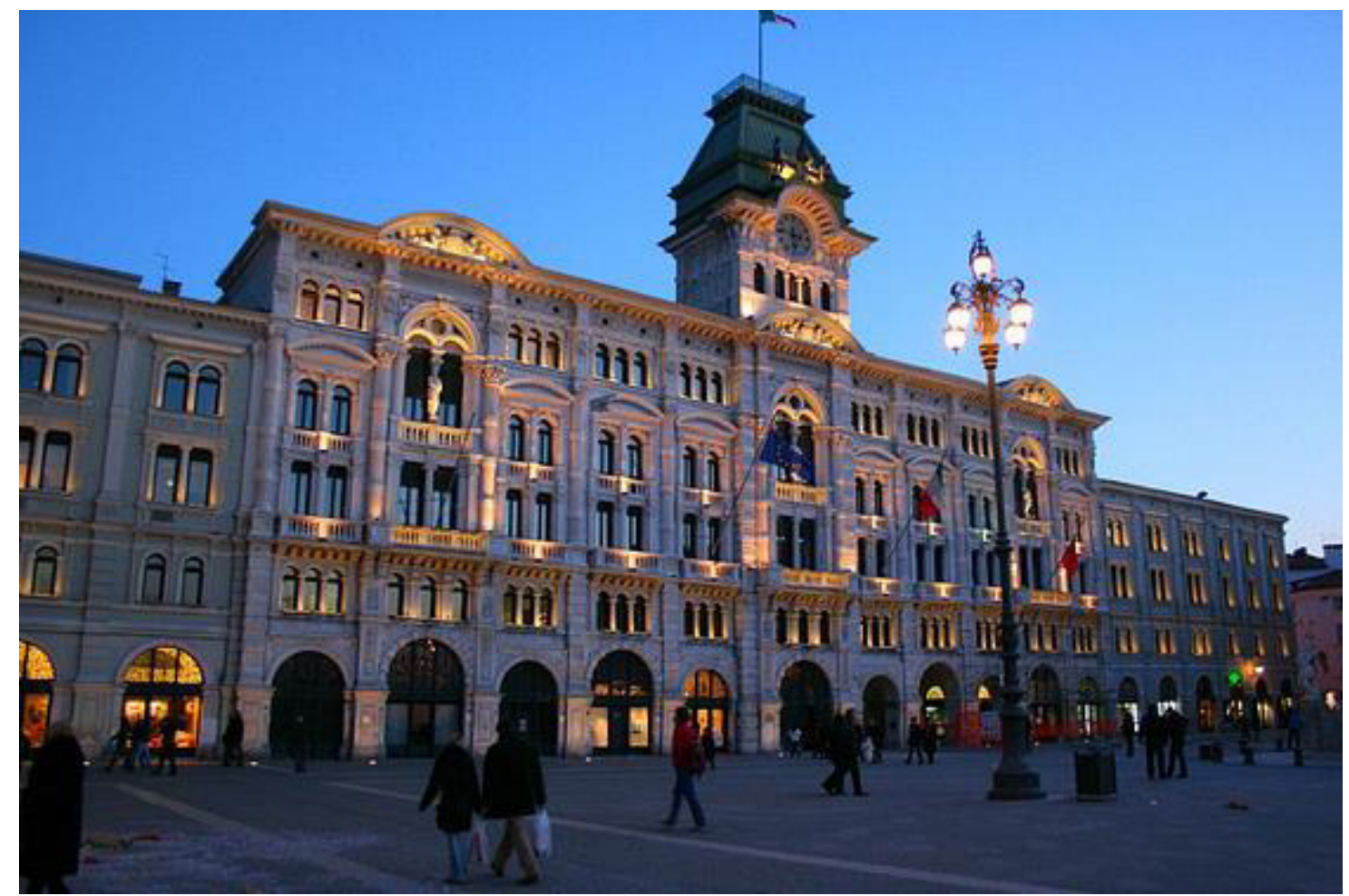

Biblioteca Civica di Trieste

A Biblioteca Municipal de Trieste, de acordo com Marani, é para Alfonso Nitti um local de solidão e sublimação (MARANI, 2003, p.30). É neste ambiente de absorção de conhecimento que Alfonso refugia-se do trabalho, que Ihe é hostil e não Ihe dá satisfação ou prazer. Nesse espaço aberto ao saber, Nitti busca a fuga de sua cruel e cinzenta realidade, entregando-se à leitura e à construção de uma realidade fictícia, permeada por fantasias, para assim poder suportar o trabalho do dia seguinte.

No mesmo trecho Nitti descreve seu quarto na casa Lanucci, um cômodo simples, que não the permite sequer dedicar-se à leitura, sua grande paixão. Assim como o banco, o humilde quarto que Alfonso alugara não lhe dá satisfação, são locais áridos que fazem o protagonista buscar outros "esconderijos". Para Marani, a casa Lanucci constitui-se no covil de todos os 
temores, que assim como ratos escondem-se para sair à noite e morder Alfonso em seu estado de repouso. É nesse quarto sombrio que Alfonso escreverá tristes cartas à mãe e colocará fim à sua vida (MARANI, 1993, p.30$31)$.

Os ambientes externos, neste romance, concentram-se principalmente no Passeggio Sant'Andrea (que também será palco de vários encontros entre Emilio Brentani e Angiolina Zarri, personagens do segundo romance de Svevo, Senilità), na Strada di Opicina e no Corso, e representam verdadeiros elos com os ambientes internos, que são mais explorados. Toda a história de Alfonso concentra-se em três locais: o banco e a casa Maller, e a casa Lanucci, em especial, o quarto alugado por Alfonso. Tais espaços atuam como protagonistas na história de Nitti e reiteram a imagem de uma Trieste lúgubre e burguesa, totalmente ligada ao comércio e ao sistema capitalista, que oprime e hostiliza Alfonso Nitti. 


\subsection{Senilità: Trieste e seus ambientes externos}

Escrito entre os anos de 1896 e 1897, o segundo romance do escritor triestino Italo Svevo, é publicado primeiramente, em capítulos, de junho a setembro de 1898, no jornal L'Indipendente, sendo que em outubro do mesmo ano é impresso em um único volume, com todas as despesas pagas pelo próprio escritor, pela editora Vram de Trieste.

O enredo, grosso modo, gira em torno da conturbada relação afetiva entre Emilio Brentani e Angiolina Zarri. Ele, um solteirão de 35 anos, simples empregado de uma firma de seguros que no passado publicara um livro, com relativo sucesso e que the rendeu certa fama de literato, a qual não se manteve por sua inércia, vive uma monótona e opaca existência ao lado de sua irmã Amália, até conhecer a jovem Angiolina, por quem se apaixona perdidamente.

O que deveria ser um passatempo para Emilio, transforma-se em uma dolorosa experiência, marcada pelo seu excessivo ciúme e pelas traições de Angiolina. Brentani não conseguirá libertar-se de seu mundo fictício e encarar o verdadeiro caráter da amante.

A obra, como o próprio escritor declarou no prefácio de sua segunda edição, não obteve, na época, nenhum elogio ou censura da crítica. Svevo atribuiu o "fracasso" do romance às vestes humildes com que o livro fora apresentado. Senilità, conforme palavras do poeta Eugenio Montale em seu famoso texto Omaggio a Italo Svevo, poderia ser considerada a obra-prima de Svevo, já que é um texto de rara potência (Montale, 1925, p.807). 
Se em Una vita, Trieste foi caracterizada, sobretudo pelos espaços internos, em Senilità os lugares externos ganham maior destaque. O encontro entre Angiolina e Emilio, que dá início à narrativa, ocorre ao ar livre:

Pararam por muito tempo no miradouro de Santo Andrea e olharam para o mar calmo e colorido na noite estrelada, clara mas sem lua. $\mathrm{Na}$ estrada embaixo passou um carro e, no grande silêncio que os circundava, o ruído das rodas no terreno desigual continuou a chegar a eles por muito e muito tempo.

\section{$(\ldots)$}

Separaram-se depois. Ela não queria que ele a acompanhasse até a cidade e Emilio foi seguindo-a a certa distância sem saber ainda de todo desprender-se dela. ${ }^{15}$ (SVEVO, 1982, p.15, grifo nosso)

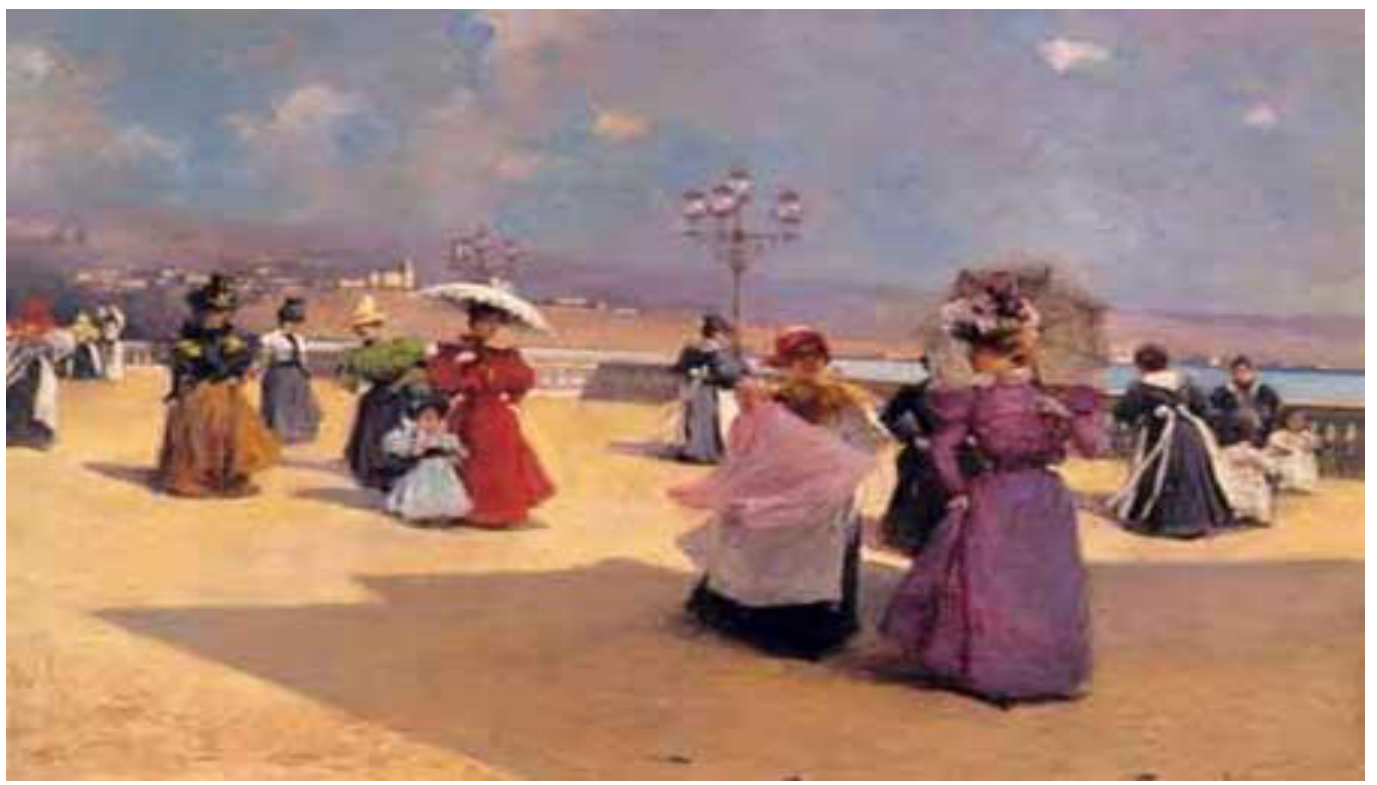

Giovanni Zangrando: II passeggio Sant'Andrea a Trieste, 1898, olio su tela, (collezione privata)

\footnotetext{
${ }^{15} \mathrm{Si}$ fermarono a lungo sul terrazzo di S. Andrea e guardarono verso il mare calmo e colorito nella notte stellata, chiara ma senza luna. Nel viale di sotto passò un carro e nel grande silenzio che li circondava, il rumore delle ruote sul terreno ineguale continuò a giungere fino a loro per lunghissimo tempo. (...) / Poi si lasciarono. Ella non volle ch'egli l'accompagnasse in città ed egli la seguì a qualche distanza non sapendo ancora staccarsene del tutto. In SVEVO, Italo. Romanzi e "continuazioni". Milano: Mondadori, 2006, pp.406-407.
} 
De acordo com Marani, os encontros amorosos entre Emilio e Angiolina acontecem ao longo do Passeggio Sant'Andrea, imortalizado na bela pintura de Giovanni Zangrando intitulada II passeggio Sant'Andrea a Trieste, de 1898. O crítico italiano o descreve como uma estrada panorâmica um pouco distante da cidade, perto do mar, e que naquela época era um ponto de encontros secretos. Tratava-se de um local tranquilo, refinado pela pequena estação de Sant'Andrea e pela praia de areias finas. Hoje tal lugar perdeu um pouco do romantismo de outros tempos, romantismo que Emilio imprimirá em suas descrições, que nos são dadas por intermédio do narrador (MARANI, 2003, p.15).

Ainda segundo Marani, nos livros de Italo Svevo quase todas as mulheres se compram, como por exemplo, Angiolina Zarri com guloseimas e Carla Gerco (amante de Zeno Cosini) com o som das moedas. Assim, Trieste torna-se um grande bordel, no qual o Passeggio Sant'Andrea seria um pequeno salão elegante onde se encontram belas senhoras, onde todos se divertem, se insinuam, se tocam; o Corso seria a escada iluminada que dá acesso aos andares superiores e, os quarteirões do Giardino Pubblico, a alcova onde se paga e se consuma (MARANI, 2003, pp.24-25).

O Passeggio Sant'Andrea que marca o início da relação do casal é substituído, pois se tornara muito frequentado; os "apaixonados" parecem preferir lugares ermos, que sejam testemunhos da relação clandestina, não oficializada, "proibida":

Encontravam-se sempre ao ar livre, namoravam em todas as ruas suburbanas de Trieste. Depois dos primeiros encontros, 
abandonaram Sant'Andrea, que era muito frequentado, e por algum tempo preferiram a estrada de Opicina, flanqueada de frondosos castanheiros-da-índia, larga e solitária, com uma subida lenta e quase insensível. Pararam perto de um trecho de muro que se tornou a meta de seus passeios só porque na primeira vez se haviam sentado ali. Beijavam-se demoradamente, a cidade a seus pés, muda, morta, como o mar, que lá de cima nada mais era que uma extensão de cor misteriosa, indistinta: e, na imobilidade e no silêncio, cidade, mar e colinas pareciam um só todo, a mesma matéria forjada e colorida por algum artista fantasioso, dividida, cortada por linhas assinaladas por pontos amarelos, os semáforos das ruas. ${ }^{16}$ (SVEVO, 1982. pp.31-32, grifo nosso)

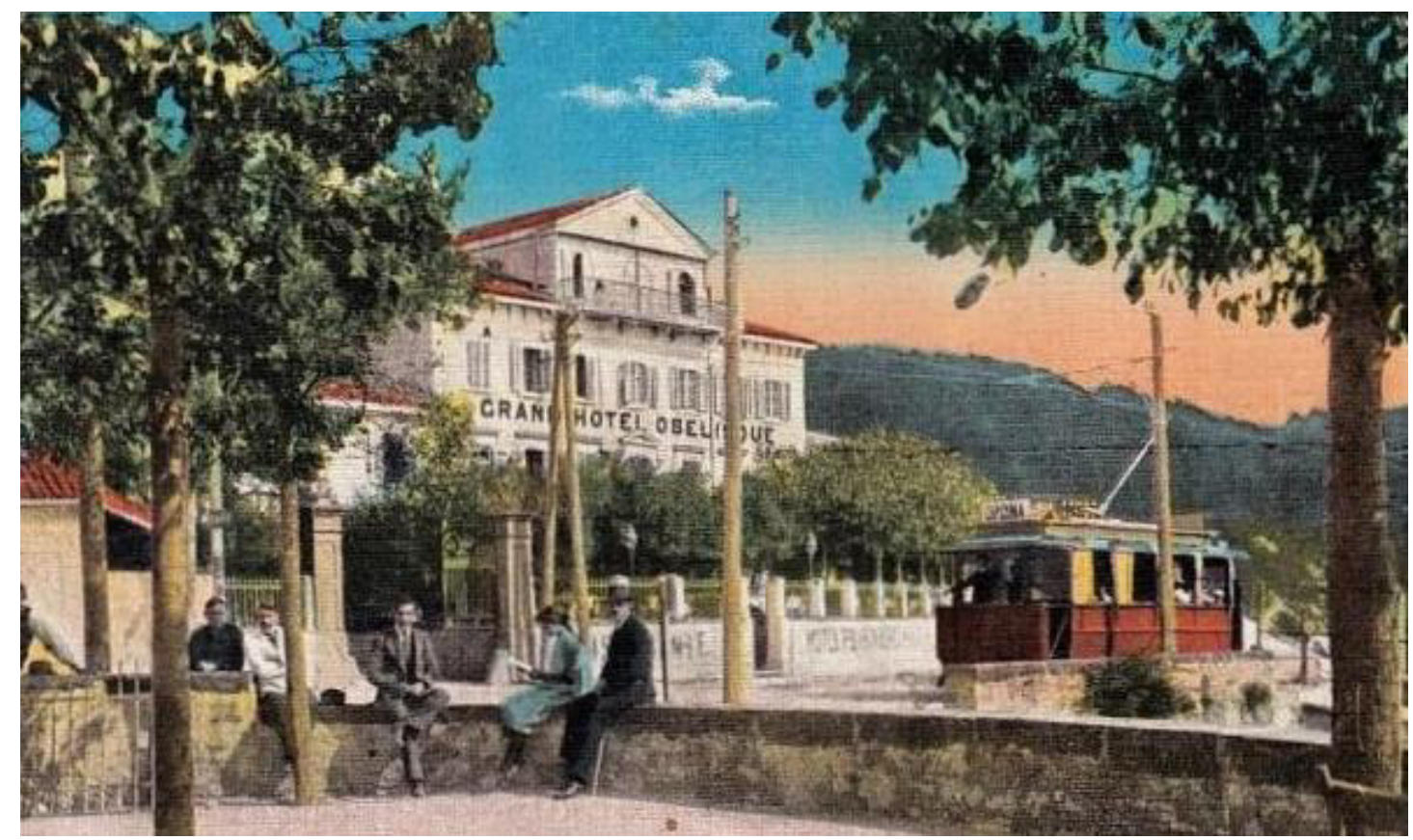

Scorcio di Opicina negli anni d'oro dell'Hotel Obelisque

\footnotetext{
${ }^{16} \mathrm{Si}$ trovavano sempre all'aperto. Amarono in tutte le vie suburbane di Trieste. Dopo i primi appuntamenti, abbandonarono Sant'Andrea ch"era troppo frequentato, e per qulache tempo preferirono la strada d'Opicina fiancheggiata da ippocastani folti, larga, solitaria, una salita lenta quasi insensibile. Si fermavano a un pezzo di muricciuolo che divenne la meta delle loro passeggiate soltanto perché la prima volta vi si erano assisi. Si baciavano lungamente, la città ai loro piedi, muta, morta, come il mare, di lassù niente altro che una grande estenzione di colore misterioso, indistinto: e nell'immobilità e nel silenzio, città, mare e colli apparivano di un solo pezzo, la stessa materia foggiata e colorita da qualche artista bizzarro, divisa, tagliata da linee segnate da punti gialli, i fanali delle vie. Ibid,, pp.419-420.
} 
A encantadora estrada de Opicina da época de Svevo é hoje, segundo Marani, um local mais perigoso devido ao intenso tráfego de automóveis e pessoas, o que não ofereceria a privacidade buscada pelos amantes. Note-se que a cidade e a mulher são identificadas pelo signo da beleza e ambas seduzem. De fato, a bela Trieste sofre um processo de personificação, ganha vida, porém permanece muda, não se manifesta, apenas observa e é conivente com o segredo dos amantes. A cidade torna-se a maior cúmplice da relação conturbada do casal. O narrador a descreverá, neste romance, sempre de modo mais romântico. Contudo, como bem destacou Marani, mudar o local de encontro não mudará a essência da relação do senhor Brentani e da senhorita Zarri (MARANI, 2003, p.18).

Após a estrada de Opicina, o casal decide mudar novamente o local de encontro; "passaram depois a preferir os pequenos bosques da Colina do Caçador; sentiam-se cada vez mais a necessidade de segregar-se. Sentavamse ao lado de uma árvore qualquer e comiam, bebiam e beijavam-se"17 (SVEVO, 1982, p.32, grifo nosso). É constante durante a relação dos amantes a busca por novos lugares para se encontrarem e, também, para se afastarem do resto do mundo. Esse isolamento implica uma bifurcação: de um lado reitera que a relação de ambos não passa de uma aventura clandestina, do outro aponta o caráter ciumento e, acima de tudo, inseguro de Emilio que quer a mulher somente para si, ansiando que ela viva a sua ilusão, sem contato com o verdadeiro mundo real. Desse modo, as descrições da cidade também passam

\footnotetext{
17 Poi preferirono i boschetti del colle al Cacciatore; sentivano sempre più il bisogno di segregarsi. Sedevano accanto a qualche albero e mangiavano, bevevano e si baciavano. Ibid., p. 420.
} 
pelo filtro emocional e ficcional de Brentani, que descreverá uma Trieste ainda mais fascinante e envolvente.

Como já dissemos, neste romance há a predominância da descrição dos ambientes externos, fundamentais para o leitor entrar em contato com a bela e multifacetária Trieste, de Svevo. Outra hipótese para o relacionamento dos amantes, na maioria das vezes, ocorrer em locais abertos é o desejo e necessidade de Angiolina ser vista, assim tais ambientes atuam como uma espécie de "vitrine viva" na qual a moça poderá observar e ser observada por “amantes” em potencial. Passemos, então, à descrição de alguns ambientes internos que consideramos importantes para a caracterização da cidade no texto.

“O prédio de Angiolina ficava situado poucos metros além da Rua Fabio Severo. Grande e alto, em meio ao campo, tinha todo o aspecto de um quartel; (...) nada de imundície, mas tudo muito pobre"18 (SVEVO, 1982. p.37, grifo nosso). A fachada do edifício da senhorita Zarri chama atenção pela pobreza, que Brentani já esperava, contudo o quarto da moça o surpreende:

Só um pouco mais tarde reparou no quarto em que se achavam. A forração não era muito nova, mas os móveis, dada aquela escada, o corredor, as roupas da mãe e da irmãzinha, eram supreendentemente bons, todos de nogueira; a cama coberta por uma colcha de franja comprida, num canto havia um vaso enorme com longas flores artificiais, e em cima, na parede, agrupadas com grande capricho, muitas

\footnotetext{
${ }^{18}$ La casa d'Angiolina era situata a pochi metri fuori della via Fabio Severo. Grande e alta, in mezzo alla campagna, aveva tutto l'aspetto di una caserma. (...) niente di sudicio ma tutto povero. Ibid., p. 424.
} 
fotografias. Luxo, em suma. ${ }^{19}$ (SVEVO, 1982, pp.39-40, grifo nosso)

O dormitório de Angiolina, quarto do pecado como o define Marani, não condiz com a aparência externa nem com a escadaria do local (MARANI, 2003, p.16). Emilio observa tudo e fica surpreso, no entanto não questiona a amante, em seu íntimo sabe que o luxo encontrado deve-se ao dinheiro ganho por Angiolina em seus outros envolvimentos. As muitas fotografias na parede são de homens, que provavelmente contribuíram com o conforto do ambiente. Tais imagens despertarão o ciúme de Brentani, mas o analisaremos posteriormente.

Esses retratos remetem-nos à descrição da sala de jantar da casa Maller, onde Alfonso também se impressiona com o grande número de pinturas na parede, que apontam para o poder de consumo da família Maller. Angiolina faz parte de outra casta social, muito inferior a dos Maller e também de seu amante. Assim as fotografias penduradas podem ser interpretadas como troféus dos homens seduzidos pela bela senhorita Zarri.

Outro ambiente interno que merece destaque é a casa de Emilio, que nos é assim descrita:

O pequeno apartamento compunha-se de apenas três aposentos aos quais, por um corredor, se chegava através daquela única porta. Por isso, quando havia alguma visita no

\footnotetext{
${ }^{19}$ Appena più tardi vide la stanza in cui si trovavano. La tappezzeria non ne era troppo nuova, ma i mobili, date quelle scale, quel corridoio e vestiti della madre e della sorella, sorprendemente ricchi, tutti dello stesso legno, noce, il letto coperto di un drappo con larga frangia, in un canto un vaso enorme con alti fiori artificiali e di sopra, sulla parete, aggruppate con grande accuratezza, molte fotografie. Del lusso insomma. Ibid., p. 426.
} 
quarto de Emilio, a irmã ficava prisioneira em sua própria habitação, que era a última. ${ }^{20}$ (SVEVO, 1982, p.76)

(..)

A estreita sala de jantar, além da belíssima mesa de madeira castanha marchetada, o único móvel da casa a demonstrar que a família no passado fora rica, continha um sofá um tanto gasto, quatro cadeiras de formas semelhantes mas não de todo idênticas, uma poltrona grande de braços e um velho armário. A impressão de pobreza que a sala transmitia era ampliada pelo cuidado com que as pobres coisas eram mantidas. ${ }^{21}$ (SVEVO, 1982, p.77, grifo nosso)

O apartamento, onde moram Emilio e a irmã, Amalia, também é humilde; a descrição ressalta e confronta dois aspectos: a mesa de madeira que demonstra que a família fora rica no passado, e os objetos da sala que, apesar de bem cuidados, ampliam a noção da pobreza da família, sustentada apenas com a renda do irmão, que deve ser baixa, pois ele é um simples funcionário em uma empresa de seguros. Assim, temos representada uma classe social decadente, que tivera um passado abastado, do qual restaram apenas o sobrenome de família e/ou algum objeto que aponta para essa época gloriosa, além da cultura que a antiga riqueza lhe permitira adquirir.

Outra evidência que indica que a família Brentani pertencera a uma classe social bem abastada é o cumprimento de "uma rica senhora, de nome

\footnotetext{
${ }^{20}$ |l quartierino si componeva di tre sole stanze alle quali, dal corridoio, si accedeva per quell'unica porta. Perciò, quando capitava qualche visita nella stanza di Emilio, la sorella si trovava prigioniera nella propria ch'era l'ultima. Ibid, p.457.

${ }^{21}$ II piccolo tinello, oltre al tavolo belissimo di legno bruno intarsiato, l'unico mobile della casa dimostrante che in passato la famiglia era stata ricca, conteneva un sofà alquanto frusto, quattro sedie di forma simile ma non identica, una seggiola grande a braccioli ed un vecchio armadio. L'impressione di povertà che faceva la stanza era aumentata dall'accuratezza con cui quelle povere cose erano tenute. Ibid., p. 458.
} 


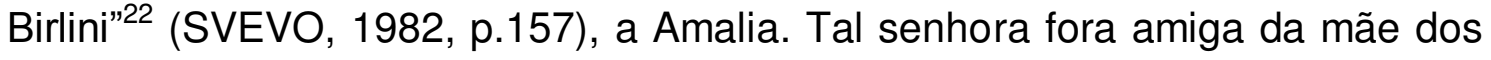
Brentani. Essa cortesia ocorre no teatro municipal, símbolo imponente de uma cidade ligada não só às artes, mas à elegância e ostentação de uma classe social rica que trafegava na Trieste no final do século XIX.

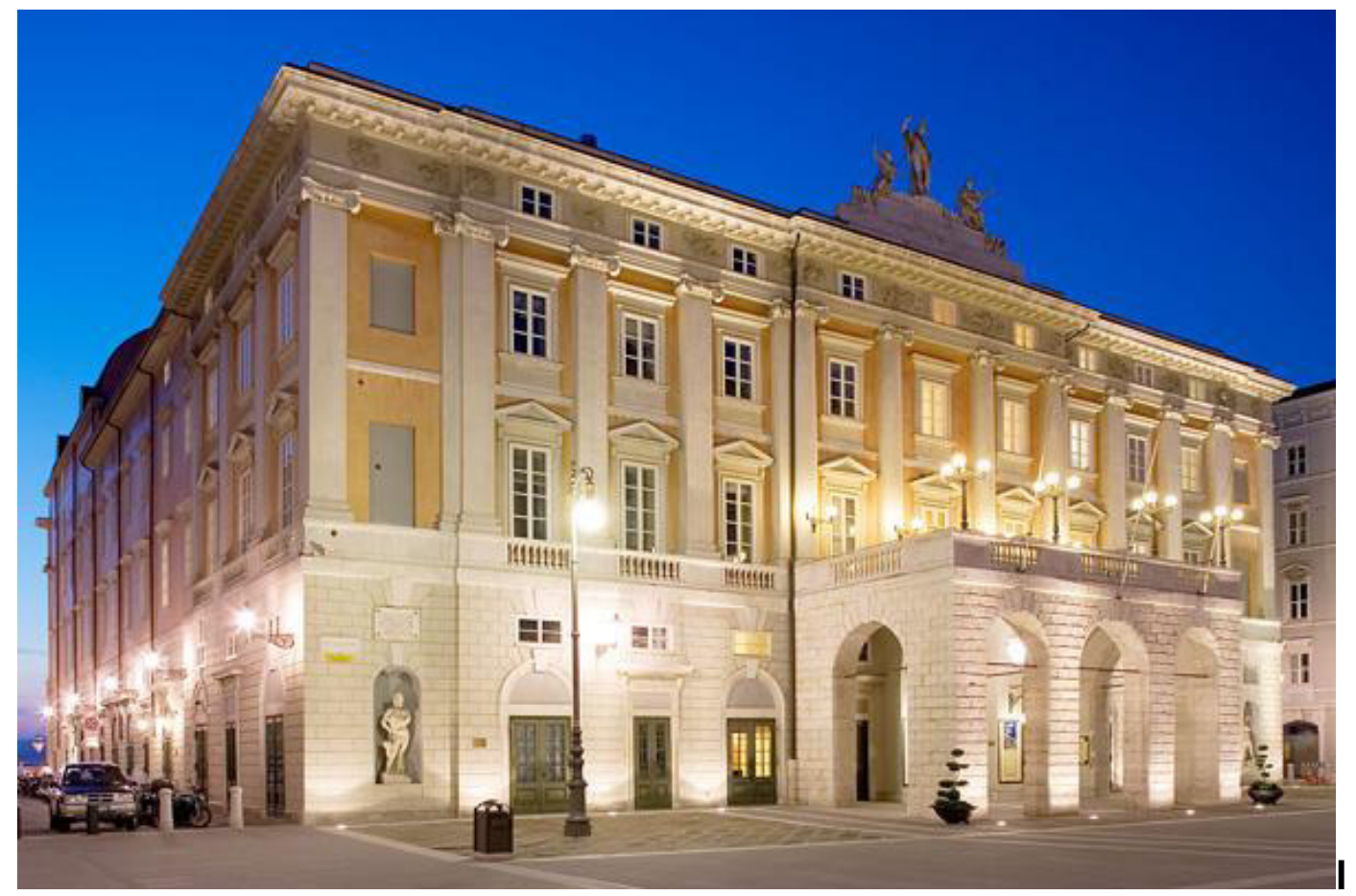

Teatro Verdi di Trieste

O belíssimo Teatro Verdi, chamado anteriormente de Teatro Nuovo, é um dos mais antigos teatros líricos em atividade. Construído entre os anos de 1798 e 1801 pelos arquitetos Gian Antonio Selva e Matteo Pertsch. Foi inaugurado em 21 de abril de 1801 com o drama heroico Ginevra di Scozia, do compositor alemão Simone Mayr.

\footnotetext{
${ }^{22}$ Una certa Birlini, una ricca signora lbid., p.524.
} 
As atividades culturais e artísticas do Teatro, no decorrer dos anos de 1800, foram intensas e representaram a identidade de Trieste daquela época, em especial a italiana, ao difundir o conhecimento da cultura musical italiana.

De acordo com Ghidetti, Trieste pode ser chamada de uma "cidade de teatro", que não viveu apenas o reflexo do que ele chama de "teatromania vienense", mas buscou na exaltação patriótica, nutrida por uma burguesia de sentimentos italianos, o seu mote principal (GHIDETTI, 1992, p.67). Trieste, sem dúvida, constituiu-se em grande palco para a representação das artes. 0 fato da cidade, à época da juventude de Svevo, ter cinco teatros abertos ao público, para Rimini ${ }^{23}$, consagrou Trieste como "uma das praças teatrais italianas mais frequentadas pelas companhias e das mais refinadas quanto aos gostos do público" (RIMINI, 1974 Apud VICENTINI, 1984, p.21).

A Trieste descrita neste segundo romance, sem dúvida ambienta-se nos espaços exteriores. Através do narrador, que nos descreve a partir do olhar sentimental e ficcional do protagonista, somos convidados a conhecer uma Trieste apaixonante, que protagonizará a história de paixão e ciúme de Emilio Brentani e Angiolina Zarri. A cidade não apenas será confidente desse relacionamento, mas a testemunha de duas classes sociais que tentam conviver em harmonia: a decadente, impressa na representação da família Brentani, que já possuíra certa nobreza, mas perdera o poder de compra; e àquela que busca ascensão social, representada pela figura de Angiolina Zarri,

\footnotetext{
${ }^{23}$ RIMINI, R. La morte nel salotto. Guida al teatro di Italo Svevo. Firenze: Vallechi, 1974, p. III.
} 
que busca escalar socialmente através de seus atributos físicos e de sua esperteza. 


\subsection{La coscienza di Zeno: uma Trieste burguesa}

Publicado em 1923 o romance seria descoberto por Eugenio Montale dois anos mais tarde e, no ano seguinte, isto é em 1926, ganharia, conforme Marzia Vicentini, "reconhecimento francês por parte dos italianistas, Benjamin Crémieux e Valéry Larbaud, após indicação de James Joyce" (VICENTINI, 1984, p.2). A consagração tardia de Svevo, bem como "a posição particular que ele ocupou no quadro das tendências da literatura italiana contemporânea" (VICENTINI, 1984, p.2) chegaram a constituir o que ficaria conhecido como o caso-Svevo:

se poderia pensar que o verdadeiro caso-Svevo, de fato, não
foi o sucesso tardio deste escritor e a posição particular que ele
ocupou no quadro das tendências da literatura italiana
contemporânea, mas sobretudo a avalancha de controvérsias,
análises, estudos, diatribes, intervenções críticas,
reformulações de questões etc. que ele ocasionou.
(VICENTINI, 1984, p.2)

À diferença dos outros romances, cujo foco narrativo é em $3^{\text {a }}$ pessoa, somos convidados a conhecer o universo do romance La coscienza di Zeno através do "olhar" do senhor Cosini; com ele tomaremos nota de sua história, conheceremos seu mundo. Conforme a teoria de Poullion, poderíamos dizer que La coscienza di Zeno aproxima-se da visão com, em que se escolhe "um único personagem que constituirá o centro da narrativa... É com ele que vemos os outros protagonistas, é com ele que vivemos os acontecimentos narrados" (POUILLON, 1974, p.54). Em consequência disso, segundo Maria Celeste Tommasello Ramos, "estamos presos à visão de Zeno, e na impossibilidade de compartilharmos de outra visão, somos obrigados a permanecer com ele, 
vendo tudo através de seu ponto de vista ou procurando entender por que ele reage da forma que nos narra..." (RAMOS, 2001, p.74).

O romance não apresenta um tempo linear, cronológico dos acontecimentos. Na verdade, são os eventos vividos por Zeno que exprimem a noção temporal, já que temos uma narrativa dividida por temas, encarregados de nomear os capítulos: "O fumo", "A morte de meu pai", "A história de meu casamento", "A mulher e a amante", "História de uma sociedade comercial" e "Psicanálise". O tempo no romance, de acordo com Teresa de Lauretis, "não existe sem os acontecimentos, os quais são a fictícia realidade da narrativa" ${ }^{24}$ (LAURETIS, 1976, p.64, tradução nossa).

Zeno, já maduro, volta ao passado como mais uma tentativa de buscar a cura de sua suposta doença, representada pelo obsessivo vício do fumo, que por sua vez reflete sua incapacidade de adaptar-se ao organismo social. A "viagem" em busca de si parte da maturidade, passando por várias fases de sua existência. Presente e passado misturam-se, confundem-se e fundem-se, às vezes.

La coscienza di Zeno, reconhecida como a obra mais importante e famosa de Italo Svevo, apresenta-nos uma narrativa totalmente voltada a uma descrição mais aprofundada dos personagens e de seus comportamentos, na qual Trieste atuará como um grande cenário, onde serão explicadas e também questionadas as relações vividas entre esses personagens.

\footnotetext{
${ }^{24}$ non esiste senza gli avvenimenti, i quali sono la fittizia realtà della narrativa. In In LAURETIS, Teresa de. La sintassi del desiderio: Struttura e forme del romanzo sveviano. Ravenna : Longo Editore, 1976, p.64.
} 
Neste romance, as caracterizações se concentrarão na alta burguesia de uma Trieste mercantil e comercial. Se em Una Vita a caracterização era feita a partir do olhar do funcionário do Banco Maller, Alfonso Nitti, aqui a sociedade triestina, burguesa e capitalista, será descrita pelo viés do patrão, do rico Zeno Cosini, que sempre estará ligado, de algum modo, ao Tergesteo (Bolsa de Valores de Trieste):

Passei a frequentar o Tergesteo por indicação de Olivi, que me dizia ser esse um bom exórdio à minha atividade comercial e um lugar onde poderia recolher informações que the seriam úteis. ${ }^{25}$ (SVEVO, 2006, p.68)

Um dia, uma chuvarada imprevista obrigou-me a me refugiar no Tergesteo. Ali encontrei por acaso meu corretor, que veio informar-me terem as ações quase dobrado de preço no espaço de uma semana. ${ }^{26}$ (SVEVO, 2006, p.72)

O palácio do Tergesteo, sede da Bolsa de Valores de Trieste, inaugurado em agosto de 1842, foi restaurado várias vezes, sendo a última entre os anos de 2009 e 2011. O térreo possui uma importante galeria comercial, enquanto nos andares superiores funcionam diversos escritórios. 0 prédio constitui-se em um dos principais centros das atividades econômicas e financeiras da cidade. Italo Svevo trabalhou na filial do banco Unionbank que funcionava no primeiro andar do palácio, e seu romance mais célebre, La coscienza di Zeno, também teve sua maior parte ambientada aqui.

\footnotetext{
${ }^{25}$ Ero venuto al Tergesteo per consiglio dell'Olivi che mi diceva sarebbe stato un buon esordio alla mia attività commerciale frequentare la Borsa e che da quel luogo avrei anche potuto procurargli delle utili notizie. In SVEVO, Italo. Romanzi e "continuazioni". Milano: Mondadori, 2006, p. 686.

${ }^{26}$ Un giorno un improvviso acquazzone mi costrinse di rifugiarmi al Tergesteo. Colà trovai per caso il mio agente il quale mi raccontò che negli ultimi otto giorni il prezzo di quelle azioni s'era quasi raddoppiato. Ibid., p.690.
} 


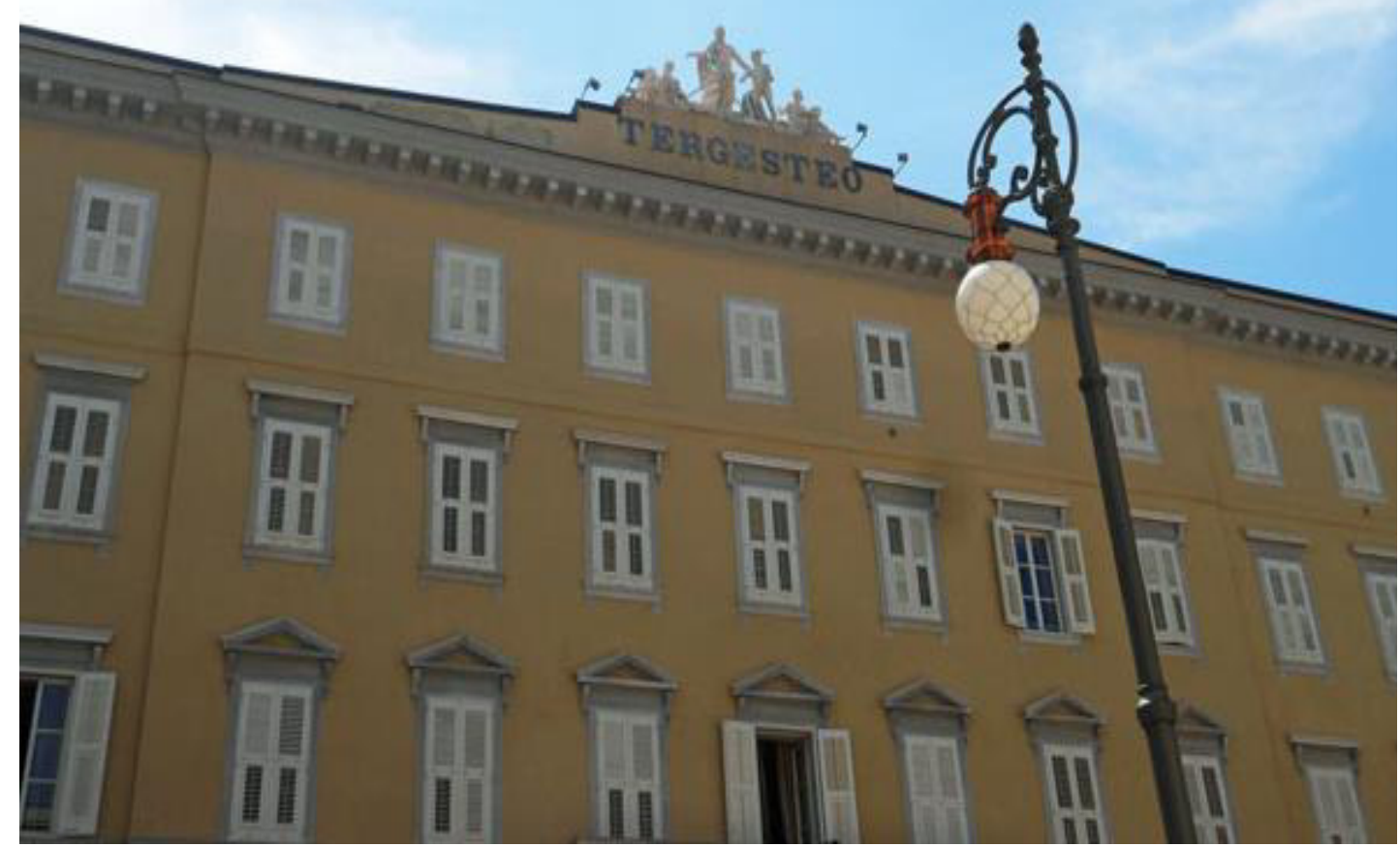

Palazzo del Tergesteo, a Trieste.

Para Marani, o Tergesteo é o templo dos negócios, onde se marcam compromissos com os corretores da Bolsa de Valores. Nele Zeno conhecerá seu futuro sogro, Giovanni Malfenti, salvará metade do patrimônio perdido pelo cunhado, além de aumentar seus bens (MARANI, 2003, p.13). Desse modo, tal prédio consolida a imagem esboçada em Una Vita, com o banco Maller, de uma Trieste comercial, totalmente voltada aos negócios, burocrática, burguesa e capitalista.

A Trieste de La coscienza di Zeno, apresenta-se como um fértil terreno para as transações comerciais e financeiras. A empresa do cunhado de Zeno, o senhor Guido Speier, ratifica tal pressuposto. O senhor Speier, que se casa com Ada, a mais bela das irmãs Malfenti, segundo Cosini, decide abrir uma casa comercial e convida Zeno para ajudá-lo, contudo Guido não entende nada 
de negócios e diante de fracassos sucessivos, ele, em uma tentativa desastrada de chamar a atenção e provocar a piedade e o consequente perdão de todos, acaba por se suicidar acidentalmente, e assim termina a "história de uma sociedade comercial".

O ambiente familiar também é de grande importância na caracterização de uma classe social bem abastada, capitalista, constituindo-se ainda em uma fiel pintura ao modo de vida da elite triestina do início do século $X X$, trazendo à tona tradições, costumes, vícios e virtudes.

Oretta Guidi, no artigo II matrimonio è in scena, secondo Italo Svevo ${ }^{27}$, defende que a temática do matrimônio, regada por represálias, crises, brigas e infidelidade, para citar algumas características, é comum na obra do escritor triestino. Afirma ainda que, para Svevo, o casamento é uma espécie de espelho da sociedade mitteleuropea, da qual ele faz parte, já à deriva, uma vez que perdeu sua centralidade e hegemonia.

O matrimônio do protagonista, com a "feia" Augusta, segundo a descrição que ele faz, é de suma importância no circuito de suas "memórias". Tal casamento, imprescindível como mais um meio de entendermos e conhecermos Zeno Cosini, é relevante, também, por ilustrar a "movimentação" de uma classe social sempre voltada às finanças. Durante a lua-de-mel, o comportamento do casal Cosini já aponta para um mundo em ascensão, regido pelo consumismo, impulsionado pela crescente e intensa evolução e fixação do capitalismo como sistema econômico. De acordo com Zeno, após as visitas a

\footnotetext{
${ }^{27}$ Disponível em: <http://www.repubblicaletteraria.it//taloSvevo.html>. Acesso em 10 jun. 2014.
} 
museus, começaram as entediantes compras da esposa. Augusta realiza vultosos gastos em todas as cidades visitadas durante a viagem de núpcias. Para ela, tais aquisições eram sólidos investimentos. Vejamos como o narrador relata esse acontecimento, fundamental para compreensão do estilo de vida do casal:

\begin{abstract}
A saúde impele à atividade e à aceitação de um mundo de enfados. Após os museus, começaram as compras. Augusta, antes de nela morar, conhecia a nossa casa melhor que eu e sabia que num quarto faltava um espelho, que outro precisava de um tapete, que num terceiro havia um lugar ideal para um bibelô. Comprei móveis para um salão inteiro e, de todas as cidades em que pernoitamos, sempre expedíamos alguma coisa para casa. Eu era de opinião que teria sido mais oportuno e menos dispendioso adquirir todas aquelas coisas em Trieste. Agora tínhamos que cuidar da remessa, do seguro e da liberação alfandegária. ${ }^{28}$ (SVEVO, 2006, p.160)
\end{abstract}

Os excessivos gastos parecem não incomodar o burguês recém-casado que desfruta de boa situação financeira. A união do casal que se dá de maneira intrigante, uma espécie de conto de fadas às avessas, termina por trazer vantagens à vida de Zeno. Ao longo da enunciação das "memórias", podemos notar que ele, de certa forma, favorecido pela sorte (DEBENEDETTI, 1995, p.80), termina por fazer um bom negócio ao casar-se com a mais "feia" das irmãs Malfenti. Augusta trará mais conforto e benefícios à vida do marido:

De regresso da viagem de núpcias, tive a surpresa de morar numa casa que nunca fora tão cômoda e acolhedora. Augusta

\footnotetext{
${ }^{28}$ La salute spinge all'attività e ad addossarsi un mondo di seccature. Chiusi i musei, cominciarono gli acquisti. Essa, che non vi aveva mai abitato, conosceva la nostra meglio di me e sapeva che in una stanza mancava uno specchio, in un'altra un tappeto e che in una terza v'era il posto per una statuina. Comperò i mobili di un intero salotto e, da ogni città in cui soggiornammo, fu organizzata almeno una spedizione. A me pareva che sarebbe stato più opportuno e meno fatisdioso di fare tutti quegli acquisti a Trieste. Ecco che dovevamo pensare alla spedizione, all'assicurazione e alle operazioni doganali. In SVEVO, Italo. Romanzi e "continuazioni". Milano: Mondadori, 2006, pp. 789-790.
} 
introduziu nela todos os confortos que havia na sua própria, além de muitos outros que inventou. O quarto de banho que na minha memória de homem sempre esteve ao fundo do corredor, a meio quilômetro do quarto de dormir, transferiu-se para o lado do quarto do casal e foi provido de um número maior de torneiras e pias. Um quartinho junto à sala de jantar foi convertido numa pequena sala íntima para o café. Coberta de tapetes e dotada de grandes poltronas forradas de couro, ali ficávamos a conversar todos os dias por uma boa hora após as refeições. Contra o meu desejo, havia ali todo o necessário para fumar. Até o meu pequeno estúdio, embora eu proibisse, sofreu algumas modificações. Temia que as alterações 0 tornassem odioso; logo, porém, percebi que só então se fizera habitável. Augusta dispôs a iluminação de modo a que eu pudesse ler sentado à mesa, refestelado na poltrona ou reclinado sofre o sofá. Para o violino foi providenciada uma estante com uma pequena lâmpada, que iluminava a partitura sem ferir os olhos do executante. Também ali, e contra a minha vontade, havia todos os apetrechos necessários para fumar tranquilamente. ${ }^{29}$ (SVEVO, 2006, p.165, grifo nosso)

Temos aqui uma pintura clara de uma típica casa burguesa. Note-se que esse lar sofre inúmeras modificações em sua estrutura física, até adequar-se totalmente às exigências do casal, que vive em meio ao luxo e conforto. A casa é projetada, como vemos, para atender aos desejos e "necessidades" de Zeno, mesmo "contra a sua vontade", como ele ironicamente enfatiza. Augusta, esposa preocupada, pensa em todos os detalhes para propiciar ao marido

\footnotetext{
${ }^{29}$ Ritornato dal viaggio di nozze, ebbi la sorpresa di non aver mai abitata una csa tanto cômoda e calda. Augusta v'introdusse tutte le comodità che aveva avute nella propria, ma anche molte altre ch'essa stessa inventò. La stanza da bagno, che a memoria d'uomo era stata sempre in fondo a un corridoio a mezzo chilometro dalla mia stanza da letto, si accostò alla nostra e fu fornita di un numero maggiore di getti d'acqua. Poi una stanzuccia accanto ao tinello fu convertita in stanza da caffè. Imbottita di tappeti e addobbata da grandi poltrone in pelle, vi soggiornavamo ogni giorno per un'oretta dopo la colazione. Contro mia voglia, vi era tutto il necessario per fumare. Anche il mio piccolo studio, per quanto io lo diffendessi, subì delle modificazioni. lo temevo che i mutamenti me lo rendessero odioso e invece subito m'accorsi che solo allora era possibile viverci. Essa dispose la sua illuminazione in modo che potevo leggere seduto sul tavolo, sdraiato sulla poltrona o coricato sul sofà. Persino per il violino fu provveduto un leggìo con la sua brava lampadina che illuminava la musica senza ferire gli occhi. Anche colà, e contro mia voglia, fui accompagnato da tutti gli ordigni necessarii per fumare tranquillamente. Ibid., pp. 794-795.
} 
mais comodidade e bem-estar, evidentes, por exemplo, na disposição de "todos os apetrechos necessários para Zeno fumar tranquilamente".

Desse ambiente interior, ou seja a casa do protagonista, que reitera os valores burgueses da época, passemos a outro ambiente também interno que será protagonizado pela relação extraconjugal de Zeno e Carla Gerco:

(...) Entramos numa dessas casas que os nossos avós costumavam constuir a quarenta anos para especulação imobiliária, em zonas distantes da cidade que com o tempo a ela se vão ligando; tinha um aspecto modesto, apesar de mais conspícuo do que as casas que se constroem hoje em dia com as mesmas intenções. A escada ocupava uma área estreita, sendo por isso bastante íngreme. ${ }^{30}$ (SVEVO, 2006, p.176, grifo nosso)

(...) Tinham conseguido sublocar uma parte do andar do fundo para diminuir as despesas do aluguel, apesar do incômodo de terem que atravessar o corredor para passasr de um aposento ao outro. ${ }^{31}$ (SVEVO, 2006, p. 177, grifo nosso)

Batemos à esquerda, na porta do estúdio onde mãe e filha, avisadas de nossa visita, nos esperavam. Copler fez as apresentações. ${ }^{32}$ (SVEVO, 2006, p.177)

Zeno, é convidado pelo amigo Copler a fazer beneficência a uma jovem cantora muito humilde, Carla Gerco, que mora com a mãe. O protagonista dá o dinheiro ao amigo para a compra de um piano para tal moça, que quer

${ }^{30}($...) Entrammo in una di quelle case cosidette di speculazione, che i nostri antenati s'erano messi a fabbricare quarant'anni prima, in posti lontani della città che subito li invase; aveva un aspetto modesto ma tuttavia più cospicuo delle case che si fanno oggidì con le stesse intenzioni. La scala occupava una piccola area e perciò era molto alta. Ibid., p. 808.

${ }^{31}$ (...) Avevano potuto subaffittare una parte del quartiere al centro e così l'affitto costava loro pochissimo, ma avevano l'incomodo di dover passare il pianerottolo per recarsi da una stanza all'altra. Ibid., p. 808.

${ }^{32}$ Bussammo a sinistra, alla stanza da studio ove madre e figlia, avvisate della nostra visita, ci attendevano. II Copler fece le presentazioni. Ibid., p. 808. 
agradecê-lo pessoalmente. Assim, dá-se o encontro entre o senhor Cosini e sua futura amante.

A situação vivida por Carla e sua mãe evidenciam uma outra classe social, muito distante da vivida por Zeno, que pela falta de posses precisa contar com a ajuda de benfeitores para manter o próprio sustento. A descrição e localização da casa alugada apontam para uma parte da sociedade triestina marginalizada sócio-economicamente. Carla, assim como Angiolina, é uma coquete de origem humilde, que busca ascender socialmente pelos atributos físicos. A diferença é que se Angiolina não recebia dinheiro de Emilio, Carla aceitará os presentes de Zeno, sem cerimônias.

A humilde moradia da senhorita Gerco servirá de alcova para os encontros com seu amante, o burguês Zeno Cosini. De acordo com Marani, Carla receberá Zeno em seu estúdio de canto, onde ele fingirá dar aulas à jovem e ela dissimulará interesse aos ensinamentos (MARANI, 2003, p.23).

O casal de amantes também se encontrará para passear no Jardim Público de Trieste:

Precisamente no início da primavera, acabei cedendo à insistência de Carla para passearmos juntos pelo Jardim Público. Aquilo me parecia altamente comprometedor, mas Carla queria tanto passear de braço comigo ao sol que acabei por concordar. Não devia ter concordado nunca, nem por um minuto, em bancarmos marido e mulher, porque essa primeira tentativa acabou muito mal. ${ }^{33}$ (SVEVO, 2006, p.245)

\footnotetext{
${ }^{33}$ Precisamente agli albori di quella primavera, io dovetti accettare di andar a passeggiare con Carla al Giardino Pubblico. Mi sembrava una grave compromissione, ma Carla desiderava tanto di camminare al braccio al sole, che finii col compiacerla. Non doveva mai esserci concesso di vivere neppure per brevi istanti da marito e moglie ed anche questo tentativo finì male. Ibid., p. 886.
} 
O Giardino storico Muzio de Tommasini, mais conhecido como Giardino Pubblico foi construído entre os anos de 1854 e 1864, sobre os terrenos que pertenciam às monjas beneditinas. Pretendia-se construir nessa área uma igreja e alguns prédios residenciais, mas tal projeto não fora aprovado. Assim, Muzio de Tommasini, prefeito de Trieste nesse período, decidiu constuir o autal jardim que leva seu nome e, é um dos locais mais visitados na cidade.

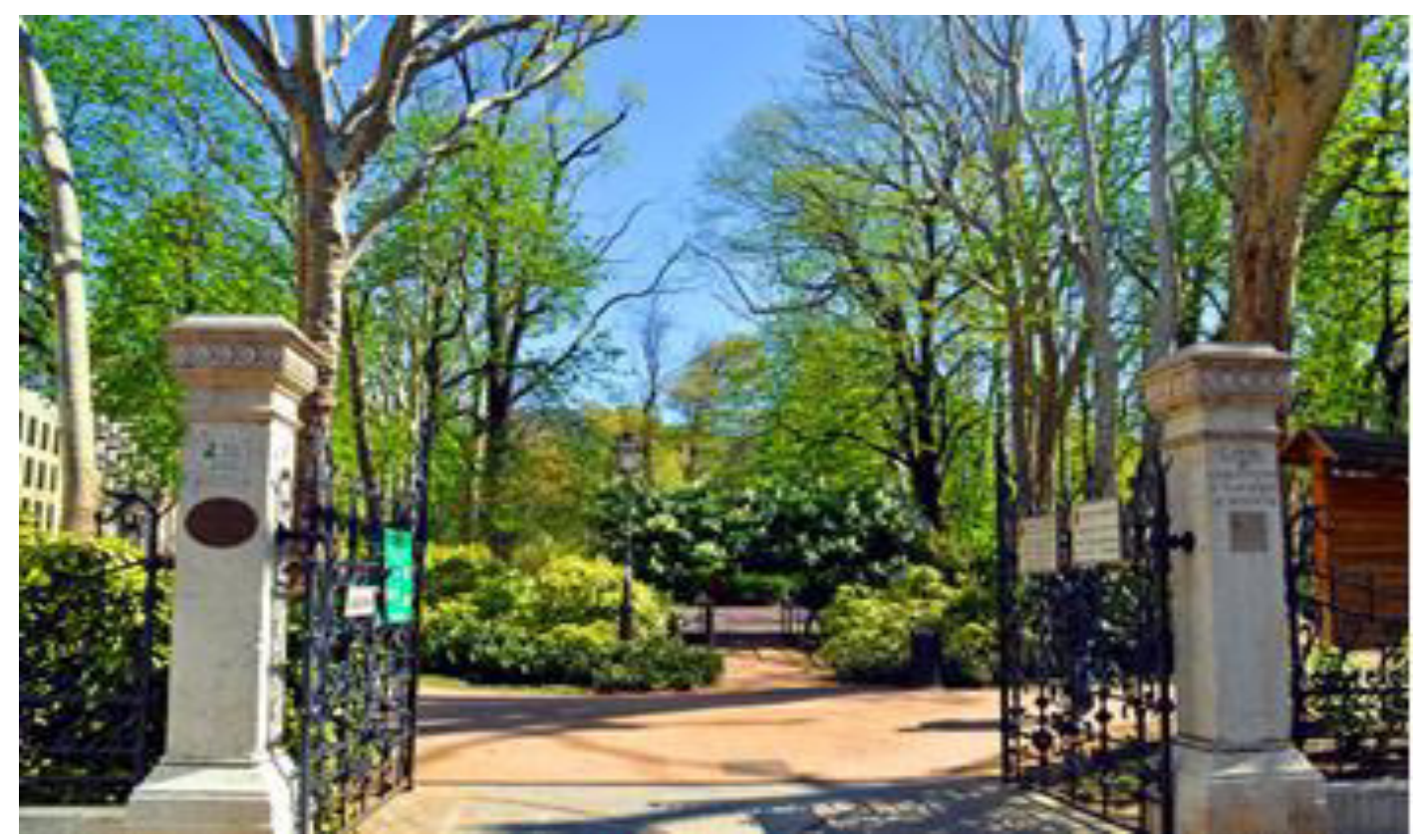

\section{Giardino Pubblico di Trieste}

Esse belo lugar constitui-se em um dos "cenários" para a relação extraconjugal de Zeno Cosini e Carla Gerco, que insiste em passear de braço dado ao amante, conforme excerto citado. Tal postura evidencia o interesse da pobre jovem em ser vista em um espaço público com um senhor mais velho e rico. Zeno, por sua vez, ainda que hesite em aceitar tal passeio, parece conduzir a amante com satisfação, como se fosse um raro objeto conquistado e 
a ser exibido, para assim evidenciar sua superioridade sócio-econômica e também para reforçar sua masculinidade.

Essa primeira tentativa de brincar de marido e mulher, como diz Zeno, não terminou bem pois o protagonista é surpreendido por um conhecido, Tullio, que sem cerimônias, pergunta quem é a bela jovem. Zeno mente e a apresenta como amiga de sua esposa; Tullio percebe que se trata de uma mentira, mas não delatará tal história a Augusta. Aqui percebemos que há uma espécie de pacto entre os dois homens, o que supõe que a situação não era incomum.

A expressão "primeira tentativa" explicita ainda que essa não será a última traição de Zeno, que ao contrário de Emilio, saberá usufruir muito bem de sua condição burguesa, para aproveitar a vida e os prazeres que essa pode proporcionar a um homem da sua classe social.

Svevo, com sua literatura que retrata a psicologia dos personagens, insere Trieste definitivamente no cenário da grande literatura italiana, fazendo de sua cidade natal, tão rica de história e cultura o pano de fundo perfeito para retratar as relações de poder nos ambientes urbanos do fim do século XIX e início do século XX. Esse homem, retratado pelo escritor, diante do mundo novo, representado pelo avanço gritante do capitalismo que é espelhado na cidade de Trieste e nos seus ambientes, demonstra-se perdido e inseguro, sendo essa insegurança, como veremos na sequência, um dos mecanismos para se entender o ciúme possessivo que tais personagens demonstram sentir. 


\section{Ciúme: as várias teorias que se interseccionam}

O ciúme apresenta-se como um sentimento amplamente discutido e teorizado através dos tempos. Não pretendemos aqui realizar um vasto panorama da presença do ciúme desde os primórdios da humanidade, mas lançar mão de algumas citações, que demonstrem o registro desse sentimento em épocas diversas e, que serão utilizadas apenas a título de exemplificação.

Se tomarmos a história dos irmãos Caim e Abel, como primeiro exemplo, veremos que movido por ciúme e inveja, Caim mata o próprio irmão. A diferença entre ciúme e inveja é tênue, e às vezes os dois sentimentos se misturam e se amalgamam. A propósito dos limites que os separam é pertinente a definição de Sergio Benvenuto. Para ele a inveja é sempre dual, implicando consequentemente duas partes: o invejoso e o invejado. Já o ciúme implica em um triângulo formado pelo eu-cimento, o outro e o rival (BENVENUTO, 2001, p.11). À esteira de Benvenuto, Melanie Klein afirma que "a inveja pressupõe a relação do indivíduo com uma só pessoa"; em contrapartida o ciúme apresenta sua base "na inveja, mas envolve uma relação com, pelo menos, duas pessoas" ${ }^{34}$ (KLEIN, 1991, p.212). Outra diferença entre tais sentimentos é defendida por Bordelois que afirma que "enquanto o invejoso deseja algo que não possui, o ciumento teme ser despojado daquilo que acredita possuir" (BORDELOIS, 2007, p.119).

\footnotetext{
${ }^{34}$ Não abordaremos no presente trabalho as relações entre inveja e ciúme, uma vez que nosso foco é apenas o segundo elemento. Acerca da tênue diferença que separa esses dois sentimentos é interessante consultar KLEIN, Melanie. Inveja e gratidão. In: Inveja e gratidão e outros trabalhos (1946-1963); tradução da 4ª edição inglesa Belinda H. Mandelbaum et al. Rio de Janeiro: Imago, 1991.
} 
Em contrapartida às definições de inveja propostas por Benvenuto e Klein, o filósofo francês, René Girard, não vê diferenças entre esses dois sentimentos. Para ele, tanto o ciúme quanto a inveja pressupõem uma tripla presença: presença do objeto, presença do sujeito e presença daquele que é alvo do ciúme ou da inveja. Tais sentimentos, ou "defeitos" como Girard os denomina são, portanto triangulares (GIRARD, 1965, p.14).

Outro exemplo canônico sobre esse assunto nos vem da mitologia grega, que também se apropriou desses sentimentos utilizando-os como tônica central de algumas tragédias, entre elas a Medeia que, ao ser abandonada pelo marido, Jasão, mata os dois filhos e a sua rival. Aqui, tem-se em cena 0 ciúme feminino que, segundo Benvenuto, foi mais explorado pelos antigos gregos se comparado ao ciúme masculino (BENVENUTO, 2007, p.24).

Mas a partir, sobretudo, do século XII com a narrativa de amor cortês, a mulher torna-se um objeto nobre do amor, sendo elevada espiritual e sentimentalmente, como consequência o ciúme masculino ganhou maior destaque por parte dos escritores. Mas será, principalmente, a partir do século XVIII que o ciumento será retratado de forma mais subjetiva e complexa (BENVENUTO, 2007, p.31), ou seja, o escritor se voltará à análise do comportamento interior desse sujeito ciumento $^{35}$, dando voz a um eu perturbado, cheio de incertezas, dúvidas, com dificuldades para entregar-se à vida e a seus prazeres. Desse modo, o ciúme passa a ser visto como mais um elemento para caracterizar tal sujeito.

\footnotetext{
${ }^{35}$ Referimo-nos aqui ao ciúme masculino.
} 
Ainda que por modos diferentes, as diversas teorias que discorrem sobre o ciúme convergem em um ponto, ou seja, no "caráter" triplo desse sentimento, cuja figura geométrica que melhor o representa é o triângulo. Tal sentimento implica três lados, ou como o definiu Barthes é "uma equação de três termos" (BARTHES, 1981, p.55), sendo que "o ser amado é desejado porque um outro ou outros mostram ao sujeito que ele é desejável; por mais especial que seja, o desejo amoroso é descoberto por indução" (BARTHES, 1981, p.127).

Greimas também insiste nesse caráter triplo quando fala sobre o ciúme. Segundo ele, tal sentimento pode ser visto como uma "paixão intersubjetiva que comporta, ao menos potencialmente, três atores: o ciumento, o objeto, o rival” (GREIMAS, 1993, p.171). Assim, "todas as definições [para o ciúme] atestam direta ou indiretamente, a existência de um anti-sujeito que ameaça sancionar o que já sancionou" (GREIMAS, 1993, p.173).

Jorge Coli, ao discorrer sobre Otelo de W. Shakespeare, ressalta que o ciúme atua do exterior (COLI, 2009, p.261), ou seja, é necessário um outro, um terceiro para ativar o ciúme latente. Esse "outro" ou "terceiro", de acordo com René Girard, seria o mediador ou rival, sobre o qual discorreremos posteriormente.

Para Freud, o ciúme também é uma "equação de três termos", contudo o pai da psicanálise ressalta que existem três camadas ou graus do ciúme: 1 . Competitivo ou normal; 2. projetado; 3. delirante (FREUD, s/d, p.271). 
O primeiro tipo é caracterizado pelo sofrimento originado através do pensamento da perda do objeto amado, bem como, por "sentimentos de inimizade contra o rival bem sucedido" (FREUD, s/d, p.271).

Já o ciúme da segunda camada, o projetado, "deriva-se tanto nos homens quanto nas mulheres, de sua própria infidelidade concreta na vida real ou de impulsos no sentido dela que sucumbiram à repressão" (FREUD, s/d, p.272).

O último tipo de ciúme, o delirante, apresenta "sua origem em impulsos reprimidos no sentido da infidelidade, mas o objeto, nesses casos, é do mesmo sexo do sujeito". Esse tipo seria, segundo Freud, "o sobrante de um homossexualismo que cumpriu seu curso e corretamente toma sua posição entre as formas clássicas da paranoia" (FREUD, s/d, p.273).

É notório o grande valor da teoria freudiana não apenas na análise do ciúme. Tanto que, diversas leituras, sobretudo do terceiro romance de Italo Svevo, La Coscienza di Zeno, seguem o viés psicanalítico. Reconhecemos ainda que as várias teorias se interseccionam e se complementam, por isso julgamos importante trazer à balia alguns estudos possíveis para análise do ciúme e também, para podermos contrastá-los com a teoria que servirá de base para o presente trabalho, ou seja, a teoria proposta por René Girard.

Girard, diferentemente de Freud, exclui a presença do pai (o complexo de Édipo) e aborda a sexualidade, um dos alicerces da teoria psicanalítica, de maneira diferente. Para ele a sexualidade não é, como fora postulado por 
Freud, o principal estímulo de nossa vida, mas um espelho que a reflete em sua totalidade (GIRARD, 2012, p.136).

Para René Girard, o ciúme, genericamente, poderia ser definido como uma irritação que provamos quando um desejo nosso é acidentalmente confrontado. Já o verdadeiro ciúme é infinitamente mais rico e complexo, uma vez que traz consigo certo elemento de fascínio nos confrontos com o rival (GIRARD, 1965, p.15).

De acordo com Gabriel Andrade a obra de René Girard, no decorrer dos anos adquiriu:

uma sistematicidade que, de início, não era sua intenção. Seus
colegas e estudiosos por vezes denominaram sua obra "o
sistema Girard" (apesar de ao próprio Girard não agradar a
ideia de sua obra ser um "sistema"), pois numa só linha
argumentativa apresenta um sistema tripartite de grande
envergadura. São três os princípios do "sistema Girard": 1) os
seres humanos desejam mimeticamente, o que gera
conflitos entre os homens; 2) a violência gerada pelos
conflitos é paradoxalmente resolvida com a mesma violência,
transformando-se assim na origem e no fundamento da
Cultura; 3) a Bíblia, especialmente os Evangelhos, é o antídoto
contra a violência cultural. De forma que, em linhas gerais, a
mimésis, a violência e o cristianismo são os três grandes temas
de que Girard se ocupou ao longo de sua obra. Esse "sistema"
emergiu apenas de forma gradual, ao longo de mais de
quarenta anos de atividade intelectual (ANDRADE, 2011, p.31,
grifo nosso).

Sem dúvida, René Girard, desponta como um grande intelectual do século $\mathrm{XXI}$, sendo reconhecido mundialmente por sua teoria mimética ou imitativa que busca analisar a cultura e o comportamento humanos, a partir da imitação de um modelo pré-estabelecido. De sua teoria, interessa-nos, sobretudo, o primeiro sistema, o do desejo mimético, primeiro pilar de sua 
ideologia, que nos permitirá visualizar o ciúme, a partir do que o teórico chama de triângulos amorosos (GIRARD, 2009, p.38).

Conforme sua ideologia, toda relação amorosa é triangular. O terceiro elemento que compõe um dos vértices do triângulo pode ser chamado de mediador ou rival, sendo ele o responsável por provocar certo sentimento no sujeito-desejante. Tal sentimento pode ser de desejo, de ódio, de inveja, de amor ou de ciúme. 


\subsection{Una vita: ciúmes e renúncia a uma paixão}

A teoria mimética proposta por Girard é bastante dinâmica, uma vez que o modelo escolhido a ser imitado pode posteriormente ser o rival, ou ainda transformar-se no sujeito-desejante. O rival ou mediador é importante para despertar desejo no sujeito-desejante, que terá seu desejo aumentado ao saber que seu objeto de desejo também desperta interesse em um terceiro elemento.

No romance de estreia de Svevo, Una vita, a formação do triângulo amoroso, e consequentemente a presença do ciúme não ocorre de imediato. A princípio, Alfonso parece não se interessar por Annetta:

Era uma moça bonita, apesar de, como disse a Miceni, seu rosto largo e rosado não lhe ter agradado. Alta, com um vestido claro que realçava suas formas pronunciadas, não podia agradar a um sentimental. Com formas tão perfeitas Alfonso descobria que os olhos não eram suficientemente escuros e que os cabelos não eram crespos. Não saberia dizer por que, mas teria gostado que fossem. ${ }^{36}$ (SVEVO, 1993, p.37)

Conforme relato do narrador, a senhorita Maller não agradaria a um sentimental, no caso Alfonso Nitti, que parece desejar uma mulher com outros traços. Contudo, a vitalidade e a independência da moça parecem aguçar os sentidos e o desejo de Alfonso. Outro elemento relevante que desperta o

\footnotetext{
${ }^{36}$ Era una bella ragazza, quantunque, come egli disse a Miceni, il suo volto largo e róseo non gli piacesse. Di statura alta, con un vestito chiaro che dava maggior rilievo alle sue forme pronunciate, non poteva piacere ad un sentimentale. In tanta perfezione di forme Alfonso trovava che l'occhio non era nero abbastanza e che i capelli non erano ricci. Non sapeva dire perché, ma avrebbe voluto che lo fossero. In SVEVO, Italo. Romanzi e "continuazioni". Milano: Mondadori, 2006, p.35.
} 
desejo de Nitti por Annetta relaciona-se aos rumores do relacionamento entre seu patrão e a governanta da casa dos Maller, a senhora Francesca, amiga da mãe de Alfonso:

Pela primeira vez sonhou tornar-se amante de Annetta. A coisa parecia-lhe menos impossível agora que a via no meio daquelas intrigas das quais não se poupara, com isso o sonho ficava mais fácil. Não soube porém sonhar que era amado...teve um sonho luxurioso de adolescente. ${ }^{37}$ (SVEVO, 1993, p.110, grifo nosso)

Porém, desejava rever Annetta e mais intensamente que a primeira vez. Antes tratara-se de conseguir a benevolência da filha do patrão, agora amava-a! Aquilo devia ser o amor, o desejo por uma pessoa e por nenhuma outra. la apurando seus sentidos agitados, não podendo fazê-lo com o sentimento que Ihe faltava. Os poucos dias em que tentara inutilmente sufocar seu desejo, dando outra direção, sentiu que se tornara homem, adulto. Ele desejava uma mulher, aquela, e para seus sentidos todas as outras não existiam. Lembrava-se dos reparos que fizera quanto à figura de Annetta e agora admirava não ter compreendido logo que sua originalidade e sua beleza eram construídas sobre aquilo que the parecera defeito. Os olhos pouco escuros! Os cabelos pouco crespos! Annetta tinha um corpo de Vênus e sua cabeça com os olhos azuis, e os cabelos lisos como que por modéstia, era a cabeça da inteligência. Um beijo naqueles lábios que não pareciam capazes de corresponder, devia ser muito mais delicioso! ${ }^{38}$ (SVEVO, 1993, pp.110-111)

\footnotetext{
${ }^{37}$ Per la prima volta sognò di divenire l'amante di Annetta. La cosa gli pareva meno impossibile ora che la vedeva in mezzo a quelle tresche che non si curavano neppure di rimanere celate a lei; il sogno ne era reso più facile. Non seppe però sognare di venire amato...fece un sogno da ragazzo vizioso. Ibid., pp. 122-123.

${ }^{38}$ Desiderava però di rivedere Annetta e più intensamente che non la prima volta allorché per lui si era trattato soltanto di farsi ben volere dalla figliuola del suo principale. Ora l'amava! Quello doveva essere l'amore, il desiderio di una persona e di nessun'altra. Egli sottilizzava sui suoi sensi agitati non potendolo su un sentimento qualunque che gli mancava. Nei pochi giorni in cui aveva inutilmente cercato di soffocare i suoi desiderî dando loro altra direzione s'era sentito diventare uomo adulto. Egli desiderava una donna, quella, e tutte le altre, per lui, per i suoi sensi, non esistevano. Si rammentava degli appunti ch'egli aveva fatti alla figura di Annetta e ora si meravigliava di non aver subito compreso che l'originalità di quella figura e la sua bellezza erano precisamente formate da ciò ch'egli aveva qualificato per diffetti. Gli occhi poco neri! I capelli non abbastanza ricciuti! Annetta aveva una figura da Venere e quella testa con gli occhi azzurri, tranquilli, i capelli lisci quasi modestamente, era la testa dell'intelligenza. Un bacio su quelle labbra che non sembravano capaci di corrispondervi doveva essere tanto più delizioso! lbid., p.123.
} 
De acordo com Girard, "todos temos sempre um modelo que imitamos" (GIRARD, 2000, p. 85, grifo nosso). Tal modelo, não necessariamente precisa ser uma "pessoa", pode ser um comportamento, uma situação, ou até mesmo um discurso. Note-se que Alfonso parece ter consciência de seu "amor" por Annetta após saber da relação "proibida" entre seu patrão e a governanta da casa, Francesca. O desejo de Nitti por Annetta só é despertado quando ele entra em contato com essa notícia; dessa forma ele buscará imitar o "caso" fortuito que lhe fora revelado.

O protagonista, que anteriormente fizera um retrato físico da moça mais condizente com suas verdadeiras características, comporta-se como um verdadeiro apaixonado ao tentar amenizar a descrição negativa feita inicialmente. Os olhos pouco escuros e os cabelos pouco claros passam de defeitos à originalidade em um corpo de Vênus. O comportamento de Alfonso é de um verdadeiro romântico sentimental, contudo não podemos nos esquecer de um traço peculiar à narrativa sveviana, a ironia, que deve ser levada em conta na análise de tal passagem.

Após o interesse súbito por Annetta, despertado pelo desejo de imitar a relação de seu patrão com a governanta, Alfonso não demora a sofrer a primeira crise de ciúmes:

Prarchi vinha menos àquelas reuniões por andar ocupado. Fumigi dificilmente faltava, mas o mais assíduo era Spalati. Como dissera Macario, Spalati era acima de tudo um homem bonito, uma figura hercúlea, perto da qual Alfonso, mesmo alto e não magro, desaparecia. Alfonso não gostava dele. Achava-o pedante, mas odiava-o por sentir ciúmes. E tinha suas razões. Spalati era quem mais intimidade tinha com Annetta. Durante quase um ano dera-lhe aulas de literatura italiana e 
soubera ter para com ela a confiança do professor, sem cansála com muita doutrina.

Sentindo-se sempre inferior por causa de sua fala desajeitada, Alfonso tinha violentos ataques de ciúmes, tempestades em copo d'água. ${ }^{39}$ (SVEVO, 1993, p.115, grifo nosso)

O primeiro rival ou mediador na relação, não concretizada entre Alfonso e Annetta, é revelado. Entre o protagonista e a senhorita Maller não existe nada além de uma "amizade", que ela tem interesse em manter por ver em Alfonso, um aliado, ou melhor, um subalterno que Ihe ajudará na concretização de mais um de seus caprichos, a escrita de um romance. A moça parece enxergar qualidades em Alfonso que ele mesmo não consegue.

Alfonso e Spalati, seu rival, parecem nutrir o mesmo interesse pela emancipada Annetta. Ainda que não exista um relacionamento entre Nitti e a senhorita Maller, o triângulo amoroso já se estabelecera, configurando-se da seguinte forma:

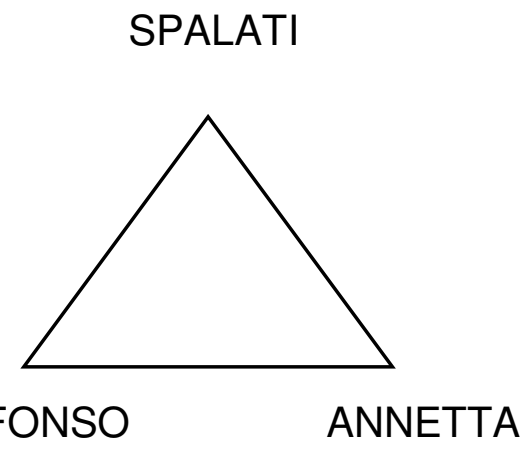

\footnotetext{
${ }^{39}$ Prarchi interveniva meno spesso a quelle serate perché molto occupato. Fumigi mancava di rado, ma il più assiduo era Spalati. Come l'aveva detto Macario, Spalati era anzitutto un bell'uomo, una figura erculea accanto alla quale Alfonso pur alto e non magro doveva scomparire. Ad Alfonso non era simpatico. Rimproverava a Spalati la pedanteria, ma l'odiava per gelosia. Ne aveva qualche ragione. Spalati era il più innanzi nella confidenza di Annetta. Per circa un anno le aveva impartito delle lezioni di letteratura italiana e aveva saputo arrivare ad avere con essa la confidenza dell'insegnante, senza seccarla con troppa dottrina. I Sentendosi sempre inferiore con la su parola impacciata, Alfonso ebbe degli assalti violenti di gelosia, tempeste in un bicchier d'acqua. Ibid., p.129.
} 
Cada vértice do triângulo é ocupado por um personagem. Alfonso é o sujeito-desejante que busca relacionar-se com o objeto escolhido, Annetta, que não correspondeu ainda a nenhum dos dois. Spalati, que também deseja a jovem burguesa, é o primeiro rival de Alfonso. Note-se sua descrição física privilegiada: Spalati "era acima de tudo um homem bonito, uma figura hercúlea, perto da qual Alfonso, mesmo alto e não magro, desaparecia". A exemplo da descrição da mulher, o rival apresenta uma caracterização exaltada, de modo a desestabilizar o sujeito-desejante, que se sente inferior e inseguro para competir com ele.

A propósito da figura do rival, que também pode ser chamado de mediador segundo Girard, é importante ressaltar que existem dois tipos de mediação, a externa e a interna. A mediação externa, de acordo com o estudioso francês, ocorre quando não há contato propriamente dito entre sujeito e mediador. Em contrapartida, na mediação interna a distância é reduzida "para que as duas esferas penetrem com maior ou menor profundidade uma na outra". (GIRARD, 2009, p.33).

Desse modo, a mediação existente entre Alfonso e Spalati é a interna, uma vez que existe contato direto entre os dois. "Não é o espaço físico que mede a distância entre 0 mediador e o sujeito desejante. Conquanto o afastamento geográfico possa constituir-se num de seus fatores, a distância entre mediador e o sujeito é primeiramente espiritual" (GIRARD, 2009, p.33). O mediador não precisa ser, necessariamente, o outro, o/a amante na relação amorosa, mas aquele ou aquela que desperta algum tipo de sentimento no 
sujeito-desejante. Spalati desperta em Alfonso não apenas ciúmes, mas também ódio, outro sentimento triangular, de acordo com René Girard.

Após o encontro com o potencial rival, Alfonso fica desnorteado:

Perambulou pelas ruas da cidade descontente com os outros e consigo próprio. Quando sentia-se agitado, tinha o hábito de falar sozinho e, ouvindo-se monologar, percebia o quanto de ridículo havia em sua raiva. Mesmo no sonho mais abstrato, proferir uma palavra precisa traz de volta è realidade. Ele chegara a desejar Annetta, amá-la, sentir ciúme dela; ela ao contrário, mal conhecia o som de sua voz. Com quem reclamar? O que mais o ofendera, fora o frio aperto de mão que ela lhe dera à despedida, e com os olhos ainda voltados para Spalati que não parava de falar! (...)

Ironizando a si próprio, achou-se pequeno e doentio com seus desejos tão distantes da realidade, porque sonhara ser amado por Annetta! $!^{40}$ (SVEVO, 1993, p.115, grifo nosso)

A exemplo do narrador em Senilità, temos uma narração pontuada por certa rigidez com o protagonista. O comportamento de Alfonso nos é descrito como infantil, fantasioso e distante da realidade. Tal caracterização remete, sem dúvida, à figura do inapto, da qual falaremos posteriormente. Não se deve esquecer ainda que o discurso do narrador também apresenta uma pincelada de ironia, ao reiterar o comportamento sentimental do protagonista.

Alfonso é, sem dúvida, alvo não apenas de seu ciúme, mas também de seu caráter pensante, que o leva sempre à reflexão e às mais delirantes

\footnotetext{
${ }^{40}$ Gironzò per le vie della città malcontento degli altri e di sé. Avendo l'abitudine quando era agitato di monologare, doveva accorgersi del ridicolo che c'era nella sua ira. Anche nel sogno più astratto una parola precisa pronunziata richiama alla realtà. Egli era giunto a desiderare Annetta, amarla, esserne geloso; ella invece sapeva appena appena quale suono avesse la sua voce. Con chi doveva prendersela? Lo aveva offeso più di tutto la stretta di mano di congedo ch'ella gli aveva dato freddamente e tenendo gli occhi rivolti a Spalati che continuava a parlare! (...) Ironeggiando su se stesso si trovò piccolo e malaticcio coi suoi desiderî tanto sproporzionati al possibile, perché egli aveva sognato di venir amato da Annetta! Ibid., pp.129130.
} 
imaginações que nada se assemelham ao seu mundo real. Essa fuga da realidade e a resistência em integrar-se ao verdadeiro mundo que o circunda é espelho de sua inaptidão.

Aos poucos, o protagonista consegue aproximar-se de sua amada, que o convida a escrever um romance a "quatro mãos". As visitas a casa Maller, por conta dessa escritura, tornam-se mais frequentes e parecem incomodar o primo de Annetta, que no decorrer da narrativa se tornará o maior rival de Alfonso:

Alfonso acompanhou Macario até seu escritório. Parecia muito distraído e quando the disse sem seriedade que se sentia desvanecido pela proposta de Annetta e que queria corresponder à confiança com um trabalho contínuo e cuidadoso, Macario cobriu a boca com a mão como quem quer esconder um bocejo. Alfonso era um observador suficientemente arguto para não acreditar num bocejos daqueles; (...) Macario era ciumento! Tanto a distração quanto o bocejo eram afetados, querendo esconder a raiva e o desapontamento. ${ }^{41}$ (SVEVO, 1993, p.122, grifo nosso)

\section{$(\ldots)$}

Sentiu ter falado com Macario. Tinha certeza de que já não poderia mais contar com sua amizade. Talvez Macario não amasse Annetta isso ele não poderia saber, mas tinha ciúme, nem que fosse apenas por causa de seu temperamento. Alfonso não se dera conta antes de seu temperamento visto ser a primeira vez que dera a Macario motivos de ciúme. ${ }^{42}$ (SVEVO, 1993, p.123, grifo nosso)

\footnotetext{
${ }^{41}$ Alfonso accompagnò Macario al suo ufficio. Macario sembrava molto distratto e quando egli gli disse con serietà che si sentiva onorato dalla proposta di Annetta e che voleva corrispondere a tanta fiducia con un lavoro continuo e accurato, Macario si coprì la bocca con la mano come se avesse avuto da celare uno sbadiglio. Alfonso era abbastanza buon osservatore per non credere a quello sbadiglio; (...) Macario era geloso! Tanto la distrzione quanto lo sbadiglio erano affettati, intesi a nascondere un'ira, un dolore. Ibid., p.138.

${ }^{42}$ Gli dispiacque di aver parlato con Macario. Certo era che sull'amicizia di Macario egli non poteva più contare. Forse Macario non amava Annetta, Alfonso non poteva saperlo, ma era geloso di lui anche se solo per carattere geloso. Egli non aveva capito prima questo carattere perché era la prima volta che a Macario poteva aver dato ragioni di gelosia. Ibid., p.138.
} 
O bem sucedido advogado Macario começa a dar indícios de que o que sente por Annetta é mais do que uma simples amizade entre primos. Macario até então não deixara transparecer desejar a prima como mulher, contudo, Alfonso, "arguto observador", já vislumbra no advogado um rival latente. O terceiro elemento a compor o triângulo já não é mais Spalati:

\section{MACARIO}

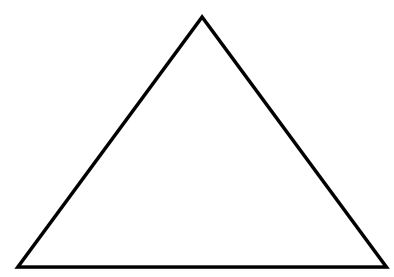

\section{ALFONSO ANNETTA}

Inicialmente, é Macario a dar mostras do ciúme pela prima, todavia Alfonso, mesmo ciente de que não existe nada entre os dois primos, passará a sentir ciúme do advogado:

Alfonso havia jurado, rangendo os dentes de raiva, vingar-se de uma palavra ofensiva que Annetta lhe dissera. Uma noite ela fora com ele mais fria que de costume. Dedicara sua atenção a Macario, que conseguira ser espirituoso com bastante sucesso e não se ocupara absolutamente dele, o que fora suficiente para despertar o ciúme do apaixonado; ${ }^{43}$ (SVEVO, 1993, p.182)

\footnotetext{
${ }^{43}$ Alfonso aveva giurato, digrignando i denti dall'ira, di vendicarsi di Annetta per una parola ofensiva ch'ella gli aveva detta. Una sera ella aveva avuto per lui maggior freddezza che di solito. Aveva badato a Macario cui era riuscito di fare dello spirito con bastante fortuna e non s'era occupata niente di lui, ciò ch'era bastato a destare gelosia nell'animo dell'innamorato... Ibid., p.212.
} 
O ciúme aqui adquire outra conotação, pois o que o desencadeia parece ser a indiferença tanto da amada quanto de Macario. O apaixonado comportase mais uma vez como um adolescente carente que necessita de atenção e de mimos o tempo todo.

O último personagem que ameaçará tirar o que não fora conquistado por Alfonso, isto é, o amor e o desejo de Annetta, será Fumigi, que também integrava as noites literárias, na casa da bela senhorita Maller:

Ele também percebera que Fumigi estava apaixonado por Annetta e era uma paixão que tinha, impossível não reconhecê-lo, muita probabilidade de alcançar seu objetivo. Pensando nisso com a cabeça fria ele era obrigado a reconhecer que Fumigi, nem muito velho e nem muito novo, era um partido conveniente para Annetta. ${ }^{44}$ (SVEVO, 1993, 140)

Fumigi também está apaixonado pela senhorita Maller, e de acordo com Alfonso é um "partido conveniente" à jovem burguesa. Outro triângulo amoroso é, então, configurado:

FUMIGI

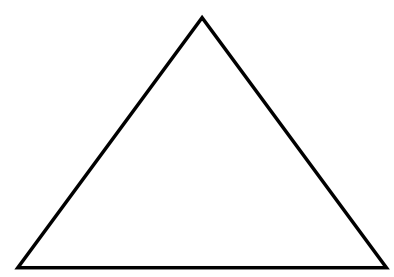

ALFONSO ANNETTA

44 Anch'egli s'era accorto che Fumigi era innamorato di Annetta ed era amore che aveva, doveva riconoscerlo, molta probabilità di giungere al suo scopo. A mente fredda comprendeva che, non troppo vecchio, Fumigi era un partito conveniente per Annetta. Ibid., p.160. 
Apesar de compor um dos vértices do triângulo amoroso e atuar como instrumento que desperta desejo, Annetta não corresponde aos sentimentos dos apaixonados. Alfonso e Fumigi "duelam" pelo amor da moça apenas em reflexões e pensamentos. Todavia, Fumigi não deixa de representar para Alfonso um rival com maior possibilidade de conquistar a jovem:

Contente como se estivesse trazendo uma boa nova, Miceni contou-Ihe que Fumigi e Annetta iam ficar noivos. Alfonso começou a rir calmamente, dessa vez de verdade.

- Pois estive ontem na casa dos Maller e teriam me dito, caso fosse verdade.

- Ainda não é oficial; mas provavelmente, enquanto estamos aqui a conversar, Fumigi está entrando pela primeira vez na casa de Annetta como noivo. ${ }^{45}$ (SVEVO, 1993, p.141, grifo nosso)

Miceni planta a dúvida em Alfonso, a exemplo do personagem lago do drama Otelo de W. Shakespeare, que incita o ciúme de Otelo, general mouro, que envenenado por este sentimento, assassina a bela e virtuosa esposa, Desdêmona. A conversa com o ardiloso Miceni desestabiliza Alfonso, que fica ainda mais inseguro e se tortura com a possiblidade da notícia ser verdadeira. Mesmo com a confirmação de que tal noivado não passara de um boato maldoso, Alfonso não consegue tranquilizar-se:

Não era mais a dor que pouco antes o lançara às ruas da cidade, mas uma grande comoção, uma pena para consigo mesmo. Se Fumigi fora recusado, seu relacionamento com Annetta continuava aparentemente o mesmo; mas, na

\footnotetext{
${ }^{45}$ Lieto come se avesse apportato una buona notizia, Miceni gli raccontò che Fumigi e Annetta si fidanzavano. Alfonso si mise a ridere calmo e questa volta sinceramente calmo. / - Ero ieri a sera in casa Maller e me ne avrebbero prevenuto se fosse stato vero. / - Non è ancora ufficiale; ma probabilmente, mentre qui parliamo, Fumigi entra per la prima volta in casa di Annetta quale sposo. Ibid., p.161.
} 
verdade, seu ciúme, seus receios, a ameaça que pairava o tornavam insuportável. ${ }^{46}$ (SVEVO, 1993, p.147, grifo nosso)

É evidente o caráter ciumento do protagonista. Se por um lado, como afirma Girard, e concordamos, o rival, o terceiro elemento a compor o triângulo amoroso, é responsável por aumentar o desejo do sujeito-desejante pelo objeto, por outro, contribui com o acréscimo do ciúme desse sujeito, que se torna obsessivo.

Um olhar ao objeto desejado, Annetta Maller, permite-nos dizer que ela também corrobora para despertar o ciúme dos apaixonados. Sua beleza é, agora, um dos fatores determinantes neste processo:

Nunca Annetta Ihe parecera tão bonita. Inclinada a escrever, os cabelos escuros e lisos, penteados com simplicidade, a caneta na mão graciosa, via-a pela primeira vez esquecida de sua beleza, sem a preocupação de estar ou não agradando, os lábios apertados, a testa franzida, a cabeça nobre numa atitude nobre. ${ }^{47}$ (SVEVO, 1993, p.127)

De acordo com Giovanna Miceli-Jeffries, que analisa a figura da mulher nos romances Senilità, de Svevo, e Un amore de Buzzati, o principal obstáculo que se contrapõe à conquista e à posse da mulher é o ciúme que, por usa vez liga-se especialmente ao fascínio físico que a mulher exerce no sujeitodesejante (MICELI-JEFFRIES, 1990, p.360). Somada à beleza de Annetta, que

\footnotetext{
${ }^{46}$ Non era più quel dolore che poco prima lo aveva cacciato per le vie della città, ma una grande commozione, un compianto di se stesso. Se Fumigi era stato respinto, la sua relazione con Annetta continuava immutata apparentemente; realmente la sua gelosia, i suoi timori, la minaccia che gli era stata fatta, gliela rendevano insoportabile. Ibid., p.168.

${ }^{47}$ Giammai Annetta non gli era piaciuta tanto. China a scrivere, i capelli bruni, lisci, ravviati semplicemente, nella mano leggiadra la penna, la vedeva per la prima volta del tutto dimenticata della sua bellezza, noncurante di piacere o meno, le labbra chiuse e la fronte increspata, la testa nobile in nobile atteggiamento. Ibid., p.144.
} 
sem dúvida fascina os apaixonados, destacamos a sua indiferença que também parece aguçar ainda mais o desejo de seus pretendentes. Somado a isso o caráter emancipado, desenvolto, bem articulado, alegre e seguro tornam a moça mais desejável:

A voz de Annetta surpreendeu Alfonso, esperava que fosse menos doce numa pessoa tão forte. ${ }^{48}$ (SVEVO, 1993, p.38, grifo nosso)

- Que entre, que entre! - gritou Annetta com alegria. - Vai fazer a gente dar risada. ${ }^{49}$ (SVEVO, 1993, p.39, grifo nosso)

Finalmente a conversação desviou-se por iniciativa da própria Annetta. Falou-se da iminente temporada teatral, só que mais do comportamento nas frisas e na plateia do que propriamente no palco e Alfonso manteve-se calado. Macario e Annetta divertiam-se a nomear e a descrever alguns jovens frequentadores da plateia e no momento em que Annetta começou a fazer graça, acompanhando suas tiradas com risadas longas e fragorosas que a faziam contorcer-se, pôs à mostra seu pescoço branco e cheio sobre o qual a tensão tornava visíveis algumas leves dobras, Alfonso sentiu-se constrangido. ${ }^{50}$ (SVEVO, 1993, p.105, grifo nosso)

A senhorita Maller sem dúvida apresenta características que fascinam, em especial, àqueles cuja personalidade é oposta à da bela jovem. Consequentemente, Alfonso parece buscar em Annetta aquilo que Ihe falta, sendo que essa busca é importante para seu autoconhecimento:

\footnotetext{
${ }^{48}$ La você di Annetta meravigliò Alfonso; se l'era aspettata meno dolce in un organismo tanto forte. Ibid., p.35.

49 - Che entri, che entri! - gridò Annetta con gioia, - ci farà ridere. Ibid., p.36.

${ }^{50}$ Finalmente la conversazione deviò e per opera di Annetta stessa. Si parlò dell'imminente stagione dei teatri ma più del contegno nei palchetti e in platea che sulla scena, e Alfonso stette zitto. Macario e Annetta si divertirono a nominare e a descrivere alcuni giovanotti frequentatori della platea, e dal momento in cui Annetta fece dello spirito accompagnando i suoi frizzi di certe sue risate lunghe, fragorose che la facevano contorcersi, mettere in mostra un collo bianco, grassoccio, sul quale la tensione faceva visibili poche leggere pieghettature, Alfonso si sentì impacciato. Ibid., p.115.
} 
Pela segunda vez sentiu o desejo de interromper seu relacionamento com Annetta, e sempre pelo desgosto que o invadia quando na grande amizade por ela demonstrada revelavam-se sua imensa frieza $e$ indiferença. Eram surpresas dolorosas que abalavam a inércia de sua vida, mais no hábito do que numa ideia ou num objetivo. Começava então analisar este objetivo, surpreso por não ter vivido mais em função dele ou então por vê-lo sob outra luz, por encontrar-se tão longe dele quanto antes lhe parecera estar perto. Seria uma paixão tão invencível a sua, a ponto de obrigá-lo a expor-se a tantas provações para satisfazê-la?

Mas o que adiantava essa análise? Ele se dera conta da diferença que existia entre seu modo de sentir e o dos que estavam à volta dele: ele encarava com seriedade excessiva as coisas vida devia ser isso. (...)

Quis ficar calmo, mas naturalmente seus raciocínios não o libertaram nem das dúvidas nem da agitação. Serviram para que ele não tomasse decisões às quais teria sido levado por seu gênio tão perturbado nas situações incertas, indecisas, e o salvaram da análise de seus próprios instintos e do próprio temperamento. Tomar conhecimento de si fazia-o sofrer. ${ }^{51}$ (SVEVO, 1993, pp.135-136, grifo nosso)

Vemos que tal paixão é fundamental para Alfonso conhecer-se. A frieza e indiferença de Annetta são essenciais para estremecer a inércia de Nitti, que reconhece o abismo existente entre seu modo de sentir e o dos outros. Alfonso é um verdadeiro sentimental que não consegue identificar-se com a sociedade fria e indiferente em que vive e, com a qual Annetta identifica-se totalmente.

\footnotetext{
${ }^{51}$ Per la seconda volta ebbe il Desiderio di rompere la sua relazione con Annetta e sempre per lo sconforto che lo invadeva, quando nella grande amicizia da essa dimostratagli trapelava l'immensa sua freddezza e indifferenza. Erano sorprese dolorose che lo scotevano dal vivere inerte più in un'abitudine che in un'idea o in uno scopo, e analizzava allora questo scopo, sorpreso di non esser vissuto più conformemente ad esso oppure di vederlo sotto tutt'altra luce, di trovarsi altrettanto lontano dal raggiungerlo quanto prima gli era sembrato di esserci vicino. Era una passione invincibile la sua da esporsi a tanti affanni per soddisfarla? / Ma a quale scopo tale analisi? Egli s'era accorto della differenza che correva fra il suo modo di sentire e quello di coloro che lo contornavano e credeva consistere nel prendere lui con troppa serietà le cose della vita. (...) / Volle essere calmo, ma naturalmente i ragionamenti non lo liberarono né dai dubbî né dall'agitazione. Servirono a non fargli prendere risoluzioni alle quali lo avrebbe portato il suo carattere tanto turbato nelle situazioni esitanti, indecise, e lo salvarono dall'analisi dei proprî istinti e del proprio carattere. Lo faceva soffrire il conoscerci. Ibid., pp.154-155.
} 
Sua relação com Annetta permite-Ihe não apenas ter consciência de ser diferente, mas a percepção de que vive em um mundo que parece não ser feito para ele. Assim, sua paixão pela senhorita Maller, bem como, todos os sentimentos que essa desencadeia, em especial, o ciúme, atua como mais uma chave de leitura da narrativa e de seu protagonista. Os valores encarnados e representados por sua amada convergem com os mesmos valores do primo, Macario.

Diferentemente de Alfonso, o advogado parece estar totalmente integrado à vida. A descrição de Macario é superficial, o narrador não penetra em suas mais "obscuras entranhas" como faz com Alfonso. Essa superficialidade evidencia um personagem mais pragmático em relação à vida, que não constrói um mundo ficcional, idealizado. Desse modo, a caracterização do advogado é inversa a de Alfonso, cuja "psicologia" interior é explorada visceralmente.

Macario não idealiza o mundo em que vive, não divaga em reflexões e delírios, representa muito bem seu papel de advogado, um verdadeiro burocrata, filho de uma Trieste também burocrática, conforme descrita anteriormente, por isso demonstra plena consciência de que a sociedade é uma verdadeira selva, onde somente os mais fortes e aqueles sabem agir, de modo dinâmico, sobrevivem. A relação entre o protagonista e Macario chega a ser próxima, apesar das divergências existentes entre eles:

Era a primeira vez que Macario mencionava o romance e aquele tom amigável e brincalhão foi uma surpresa agradável para Alfonso. Foi novamente o bom amigo a quem tanto agradava instruir Alfonso, que, de seu lado, fez o que pôde, 
com pouco sucesso, para retomar aquele jeito submisso das outras vezes. Não sabia mais reter a palavra que lhe vinha espontânea para completar ou retificar as ideias do outro. ${ }^{52}$ (SVEVO, 1993, p.136)

Entre os dois há uma relação, em certa medida, autoritária por parte de Macario, que procura se impor, principalmente, por sua condição socioeconômica. Assim como Stefano Balli fará com Emilio em Senilità, o advogado exerce o papel de um preceptor disposto a educar e instruir o jovem e ingênuo protagonista, que não conseguirá absorver os ensinamentos do "mestre". Como já ressaltado anteriormente, ainda que, Macario não demonstre interesse além do grau de parentesco com Annetta, ele já integra o terceiro vértice do triângulo na posição de mediador ou rival.

Assim como os outros rivais de Nitti, Macario apresenta características físicas exuberantes. Ele é "um quarentão bem apessoado, vestido com extremo apuro, alto e forte e com um rosto moreno cheio de vida..." ${ }^{53}$ (SVEVO, 1993, p.39). Sua relação com Alfonso não é tão estreita, sendo que existe uma grande diferença na maneira como cada um representa a realidade que os circunda. A limitada ligação entre os dois será quebrada com a conquista de Annetta por Alfonso e depois, com a renúncia à mesma, deixando o caminho livre para o advogado casar-se com a prima:

\footnotetext{
${ }^{52}$ Era la prima volta che Macario gli parlasse del romanzo e quel suo tono amichevolmente scherzoso diede una sorpresa aggradevole ad Alfonso. Fu di nuovo il buon amico cui piaceva tanto istruire Alfonso, il quale dal canto suo fece del suo meglio, ma invano, per riavere quel suo aspetto sommesso d'altre volte. Non sapeva più trattenere la parola che gli veniva spontanea a completare o rettificare le idee di Macario. Ibid., p.155.

53 ... un bell'uomo di quarant'anni forse, vestito com grande accuratezza, alto e forte, una fisionomia bruna piena di vita.... Ibid., p.36
} 
Estava livre, finalmente! Eram só quinze dias, mas durante esse tempo não queria lembrar-se por nada da cidade onde tinha sofrido tanto. Queria esquecer seus atos pouco honestos e os azares próprios e dos outros. Fugia de Annetta, daquela moça que se lhe entregara por curiosidade adolescente e que o perseguia com seu amor fictício, mas respirava também por sair daquele ambiente de pérfidos ou de desgraçados em que tinha sido obrigado a viver. ${ }^{54}$ (SVEVO, 1993, p.215, grifo nosso)

Após a noite de amor com a tão desejada amada, Alfonso, a conselho da própria Annetta, deveria ausentar-se por alguns dias para que a senhorita Maller conversasse com seu pai. Contudo, Nitti parece não conseguir encarar tal realidade, que para ele é uma prisão, e foge não apenas do mundo real, mas também da concretização dessa paixão. A renúncia a Annetta e, a fuga da cidade, constituem-se para Alfonso sua carta de alforria. Ainda que por pouco tempo, ele se sente liberto dessa sociedade, à qual ele não conseguira integrar-se, e da mulher que ele tanto desejara, antes da posse. A liberdade sentida pelo protagonista coloca em questão os seus sentimentos por Annetta, que certamente não foi amor, mas um capricho, ou melhor, um desejo exclusivo em possui-la.

Para Nitti, Annetta só se entregou a ele por uma curiosidade de adolescente, perseguindo-o com um amor fictício. A narrativa prova o contrário, é Alfonso quem se comporta como um adolescente sentimental, perdidamente

\footnotetext{
${ }^{54}$ Era libero finalmente! Per soli quindici giorni, ma durante i quali non voleva neppure ricordarsi della città ove aveva tanto sofferto. Voleva dimenticare le proprie azioni poco oneste e le proprie e le altrui sventure. Fuggiva Annetta, quella ragazza che gli si era data per una curiosità da adolescente e che lo perseguitava col suo amore fittizio, ma respirava anche all'uscire da quell'ambiente o di cattivi o di disgraziati in cui era stato costretto a vivere. Ibid., p.252.
} 
apaixonado, que constrói um amor ficcional que em nada condiz com a realidade nem com a mulher desejada.

A ausência de Nitti, prolongada pela doença e a consequente morte da mãe, faz com que Annetta o troque pelo primo. Neste momento o triângulo amoroso sofre outra configuração:

ALFONSO

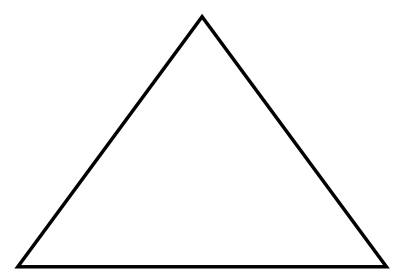

MACARIO

ANNETTA

Macario deixa de ser o latente rival para ocupar a posição de sujeitodesejante que conquista o objeto de desejo, Annetta, que entra em sintonia com o sujeito-desejante para formar um casal. Consideramos Alfonso um rival para Macario, pois o ciúme ainda faz parte de seu comportamento, o que evidencia seu caráter não apenas ciumento, mas principalmente possessivo. $O$ que Alfonso demonstrou sentir por Annetta realmente está longe de ser amor:

O que ainda podia surpreendê-lo é que a escolha tivesse recaído sobre Macario. Annetta nunca demonstrara muita simpatia pelo primo e Macario, por sua vez, falara de Annetta como se a quisesse e a amasse, mas não para casar. Odiava de tal modo as qualidades matemáticas de Annetta, suas pretensões e seus caprichos! Tinha sentido que a ele desagradasse o fato de Macario tornar-se o marido de Annetta em lugar de outro: Macario fora seu amigo e este relacionamento tornava mais difícil seu comportamento. Imaginava-se convidado ao enlace ou, quem sabe, escolhido por Macario como padrinho! 
Mas não era isso que o afligia. A si próprio não sabia mentir. Sofria por causa do ciúme e era uma dor aguda, um acabrunhamento profundo e uma coisa muito tola. Sofria as consequências de sua ação. ${ }^{55}$ (SVEVO, 1993, 268, grifo nosso)

Após sentir-se livre ao afastar-se de seu objeto de desejo, Alfonso parece sofrer com o casamento de Annetta e do primo. Nitti, na verdade, sofre pelo ciúme da perda e por ter renunciado a uma "paixão" por sua falta de atitude. Note-se que em alguns momentos seu caráter fantasioso e sonhador, que se lança a divagações não condizentes com a realidade, impera. Um exemplo disso seria sua fantasia de se ver convidado pelo antigo "amigo" para ser padrinho do enlace da mulher que já fora sua. A união entre os primos aponta para outra característica da sociedade da época: o casamento por conveniência e com pessoas da mesma casta social. Alfonso, o rapaz sonhador, jamais poderia pertencer à família Maller. Além do mais, como bem notara Miceni, "o matrimônio de Annetta e Macario seria excelente quanto à condição e ao estado dos dois noivos, bem como ao nível social"56 (SVEVO, 1993, p.275). Enfim, o novo casal partilha dos mesmos valores daquela sociedade, a qual Alfonso renega insistentemente.

\footnotetext{
${ }^{55}$ Quello che ancora poteva sorprenderlo era che la scelta fosse caduta su Macario. Annetta non aveva dimostrato mai una grande simpatia per il cugino, e a sua volta Macario aveva parlato di Annetta in modo che si poteva credere che l'amasse e desiderasse, ma non che avesse l'intenzione di sposarla. Odiava pur tanto le facoltà matematiche di Annetta e le sue pretensioni e i suoi capricci! Ragionevolmente doveva spiacergli che Macario divenisse il marito di Annetta piuttosto che un altro perché Macario era o era stato suo amico e questa relazione rendeva più difficile il suo contegno. Si vedeva invitato a nozze o magari scelto da Macario a testimonio! / Non era questo che lo affliggeva. Con se stesso non sapeva mentire. Soffriva di gelosia, un dolore acuto, un profondo avvilimento, ed era cosa molto sciocca. Soffriva dei risultati dell'opera sua! Ibid., pp.316-317.

${ }^{56}$ il matrimonio di Annetta con Macario era bellissimo, come condizione e stato dei due sposi, e come statura... Ibid., p.325.
} 
A renúncia de Alfonso à vida, pois "não sabia amar e não sabia sentir prazer" $^{\prime \prime 7}$ (SVEVO, 1993, p.333), reitera sua insegurança e incapacidade em viver a realidade, que por sua vez, gera seu ciúme possessivo por uma mulher que ele sequer ama. Seu suicídio é também a morte desse sentimento possessivo por Annetta e, consequentemente, a extinção de uma relação de desejo que sempre fora triangular desde o seu nascimento.

\footnotetext{
${ }^{57}$ non sapeva amare e non godere lbid., p.395.
} 


\subsection{0 ciúme em Senilità: fio condutor da narrativa}

Em Senilità, segundo romance de Svevo, as relações triangulares são ainda mais exploradas e atuam como fio condutor da narrativa que conta a história do "jovem senil", Emilio Brentani. Algumas semelhanças entre os personagens do conto Una lotta, publicado em três capítulos no jornal L'indipendente, em janeiro de 1888, sobre o qual já tecemos comentários na introdução deste trabalho (à página 15), com os do romance Senilità são evidentes. No conto, Rosina, do mesmo modo que Angiolina (no romance) é uma bela mulher que desperta interesse de dois homens: o famoso poeta Arturo Marchetti, cujas características serão vistas, posteriormente, no literato decadente Emilio Brentani, protagonista do romance; e o atleta Ariondante Chigi que se assemelha ao escultor, bem sucedido com o sexo frágil, Stefano Balli, amigo de Brentani, em Senilità.

Os ingredientes principais do romance já estavam, portanto, esboçados no conto. Vemos que a questão do ciúme faz-se presente na obra sveviana desde sua origem, e Una lotta é prova disso, pois já contém o embrião desse sentimento amargo que se fará presente nas outras produções literárias de Italo Svevo, em especial nos romances e, sobretudo, em Senilità.

Emilio Brentani, conforme relato do narrador, pretende iniciar uma relação com a bela Angiolina Zarri, deixando claro que isso não passará de um passatempo, um divertimento. Assim inicia-se, - e é revelada ao leitor - a aventura amorosa que o protagonista pretende viver. 
A beleza e vitalidade da mulher, objeto de desejo, também exercem grande fascínio e interesse do protagonista. Como ressaltado anteriormente, a caracterização da mulher atua como mais um elemento para despertar o ciúme do sujeito-desejante. O primeiro retrato de Angiolina, como bem observou Beatrice Stasi, limita-se à descrição de seu aspecto físico (STASI, 2009, p.81):

\begin{abstract}
Angiolina, uma loura de grandes olhos azuis, alta e forte, mas esbelta e flexível, um corpo iluminado de vida, uma coloração pálida de âmbar aspergida pelo róseo de uma boa saúde, caminhava ao seu lado, com a cabeça inclinada para um lado como se pendida pelo peso do ouro que a envolvia, olhos fitos no chão que ela a cada passo tocava com a ponta da elegante sombrinha como se quisesse fazer brotar dali um comentário às palavras que ouvia. ${ }^{58}$ (SVEVO, 1982, p.13, grifo nosso)

(...) A mulher [Angiolina] o despertara! Radiante de beleza e juventude, deveria iluminá-la toda, fazendo-o esquecer 0 triste passado de desejo e solidão, e prometendo-lhe a alegria num futuro que ela, é certo, não haveria de comprometer ${ }^{59}$ (SVEVO, 1982, p.13, grifo nosso)
\end{abstract}

A descrição de Angiolina é ainda mais exaltada se comparada à caracterização de Annetta Maller. Hipnotizado pela perfeição física da moça, Emilio parece não se importar com as histórias passadas da beldade, com a qual aos poucos entra em contato, mas prefere ignorá-las, e criar uma mulher idealizada que só existe em seu mundo ficcional. Note-se ainda que o protagonista deseja que a jovem o faça esquecer seu opaco passado. Tal

\footnotetext{
${ }^{58}$ Angiolina, una bionda dagli occhi azzurri grandi, alta e forte, ma snella e flessuosa, il volto illuminato dalla vita, un color giallo di ambra soffuso di rosa da una bella salute, camminava accanto a lui, la testa china da un lato come piegata dal peso del tanto oro che la fasciava, guardando il suolo ch'ella ad ogni passo toccava con l'elegante ombrellino come se avesse voluto farne scaturire un commento alle parole che udiva. In SVEVO, Italo. Romanzi e “continuazioni”. Milano: Mondadori, 2006, p. 404.

59 (...) La donna vi entrava! Raggiante di gioventù e bellezza ella doveva illuminarla tutta facendogli dimenticare il triste passato di Desiderio e di solitudine e promettendogli la gioia per l'avvenire ch'ella, certo, non avrebbe compromisso. Ibid., p. 405.
} 
postura evidencia claramente seu caráter inapto, que, de antemão, já se coloca em uma relação esperando que a outra parte faça o que ele não conseguirá, ou seja, livrar-se do passado apático e construir um presente diferente.

O protagonista deixa-se envolver pela sedução da moça, acreditando ter o controle da situação. Sua postura inicial demonstra isso, todavia ele apaixona-se perdidamente por ela, ou melhor, pela "Ange", "criatura inventada por Emilio, por meio de uma reescrita artística conscientemente distorcida do vivido"60 (STASI, 2009, p.89, tradução nossa). Para Ernestina Pellegrini, Angiolina, obscuro objeto de desejo, não seria apenas uma invenção de Emilio, mas uma "construção artificial" que é feita, inclusive, com a cooperação de sua irmã Amalia (PELLEGRINI, 1999, p.15). Desde o início, ele idealiza a amante, a começar pelo nome:

O nome Angiolina não the agradava à sensibilidade literária. Chamou-a Lina; depois, não Ihe bastando esse diminutivo, impingiu-lhe o nome francês de Angèle, e não raro o enobreceu e o abreviou em Ange..$^{61}$ (SVEVO, 1982, p.31)

Ainda de acordo com Pellegrini, em Senilità ganha espaço um stilnovismo às avessas, pois a mulher é mais bruxa do que anjo, ou ainda é um anjo caído e luciferino (PELLEGRINI, 1999, p.20). Angiolina, Ange, Giolona são nomes irônicos, que remetem a significados ambíguos e antitéticos, como por exemplo à pureza do anjo ou à malícia do diabo. Ange seria ainda uma

\footnotetext{
${ }^{60}$ creatura inventata da Emilio, attraverso una riscrittura artistica consapevolmente deformante del vissuto. In: STASI, Beatrice. Svevo. Bologna: Mulino, 2009, p.89.

${ }^{61}$ Per una sentimentalità da letterato il nome d'Angiolina non gli piaceva. La chiamò Lina, poi, non bastandogli questo vezzeggiativo, le appioppò il nome francese, Angèle e molto spesso lo ingentilì e lo abbreviò in Ange. lbid., p. 419.
} 
redução do nome Angelica, a protagonista bela e manipuladora criada por Boairdo e imortalizada por Ariosto, cujo nome, remete ao desejo carnal.

Paralelo à progressiva transformação do nome de Angiolina, como ressalta Stasi, tem-se o processo de angelização da mulher (STASI, 2009, p.87). A Angiolina, emancipada como mulher, sedutora, sensual, aos olhos de Emilio se transformará na ingênua Ange, que de angelical e inocente não apresenta, realmente, nada, a não ser nas quimeras do protagonista. Se tomarmos a narrativa em sua totalidade, o excerto abaixo denota ironia do narrador com o protagonista, pois Emilio tem consciência de que a "sua mulher-anjo" só existe em seus delírios:

(...) A mulher que ele amava, a Ange, era uma invenção sua, ele a criara com esforço premeditado; ela não colaborara naquela criação, sequer se deixara fazer, já que mostrara resistência. Ả luz do dia o sonho evaporava. ${ }^{62}$ (SVEVO, 1982, p.55, grifo nosso)

Angiolina, como fica evidente, é inocente nesse processo de metamorfose que the é imposta pelo amante. A exemplo de Alfonso Nitti, Brentani comporta-se ainda mais como um adolescente, que se apaixona pela primeira vez. Sua postura inicial em não querer se comprometer seriamente com a jovem vai aos poucos perdendo sentido, uma vez que ele a deseja como jamais havia desejado outra mulher. Logo após o primeiro encontro, ele demonstra um sentimento pela moça que está longe de ser descompromissado, sem vínculos mais profundos; prova disso é o ciúme que

\footnotetext{
62 (...) La donna ch'egli amava, Ange, era una sua invenzione, se l'era creata lui con uno sforzo voluto; essa non aveva collaborato a questa creazione, non l'aveva neppure lasciato fare perché aveva resistito. Alla luce del giorno il sogno scompariva. Ibid., p. 439.
} 
ele parece sentir, ao saber um pouco mais do passado da moça, que ele ignorara totalmente no primeiro encontro:

\section{Quis o acaso que ele viesse logo no dia seguinte saber a respeito de Angiolina bem mais do que ela Ihe havia contado. (...)}

Um certo Sorniani, homenzinho amarelento e magro, emérito dom-juan, segundo ele próprio dizia, mas igualmente estulto e linguarudo em prejuízo do nome alheio e do próprio, atracou-se ao braço de Emílio e perguntou-lhe como é que conhecia aquela moça. (...)

- E o que faz ela agora? - perguntou Sorniani, deixando entender que conhecia o passado de Angiolina e que estava de fato indignado por não lhe conhecer o presente.

- Isso não sei! - e acrescentou com indiferença bem simulada:

- Deu-me a impressão de ser uma pessoa distinta.

- Devagar! - fez Sorniani decidido, como se tivesse querido afirmar o contrário e, só depois de uma breve pausa, corrigisse: - Nada sei a respeito e quando a conheci todos a achavam honesta, embora se encontrasse certa vez em posição equívoca. $^{63}$ (SVEVO, 1982, pp.16-17, grifo nosso)

Emilio, por intermédio de um "amigo", obtém mais informações acerca do passado de Angiolina. O discurso de Sorniani apresenta um claro tom de intriga, cuja intenção é, sobretudo gerar dúvidas em Brentani. A função de Sorniani, neste momento, é a mesma do personagem Miceni de Una Vita, ou seja, levar o protagonista a desconfiar do caráter e da índole da mulher,

\footnotetext{
${ }^{63}$ Volle il caso che subito il giorno dopo egli risapesse sul conto dell'Angiolina ben più di quanto ella gli avesse detto. (...) / Un certo Sorniani, un omino giallo e magro, gran donnaiuolo, a quanto dicevasi, ma, certo anche vanesio e linguacciuto a scapito del buon nome altrui e del proprio si appese al braccio d'Emilio e gli chiese come mai conoscesse quella ragazza. / - E che cosa fa adesso? - chiese Sorniani facendo capire di conoscere il passato d'Angiolina e d'essere veramente indignato di non conoscerne il presente. / - Non lo so, io - e aggiunse con indifferenza ben simulata: - A me fece l'impressione di una ragazza a modo. / - Adagio! - fece il Sorniani resolutamente come se avesse voluto asserire il contrario, e soltanto dopo una breve pausa si corresse: - lo non ne so nulla e quando la conobbi tutti la credevano onesta quantunque una volta si fosse trovata in una posizione alquanto equivoca. Ibid., pp. 407-408.
} 
despertando, consequentemente, o ciúme latente de Emilio, que não demorará a ser explicitado:

Observou as fotografias. Um velho que se fizera fotografar em pose de grande senhor, apoiado sobre um monte de papéis. Emílio sorriu. - Meu padrinho - apresentou Angiolina. Um jovem vestido com roupas de domingo, um rosto enérgico, olhar ousado. - O padrinho de minha irmã - disse Angiolina -, e este é o padrinho de meu irmão mais novo - e mostrou o retrato de outro jovem mais suave e mais bem trajado que $o$ primeiro.

- Ainda há outros? - perguntou Emilio, mas a zombaria morreu-lhe nos lábios porque entre as fotografias descobrira duas juntas, de pessoas que conhecia: Leardi e Sorniani! (...)

Angiolina não compreendeu logo por que a fronte de Emilio ficara tão sombria. Pela primeira vez, brutalmente, ele deixou-se trair pelo ciúme: - Não me agrada nada encontrar tantos homens em seu quarto. (...)

De improviso explodiu em sua face uma grande hilaridade, e afirmou que estava contentíssima por vê-lo com ciúmes. Com ciúmes desta gente! - disse depois, retornando ao sério e com ar de reprovação. ${ }^{64}$ (SVEVO, 1982, pp.40-41, grifo nosso)

O ciúme que fora "plantado" em Emilio, por Sorniani, começa a germinar

e a dar forma à narrativa e à história do senhor Brentani, bem como à sua relação amorosa com Angiolina, que será sempre triangular. Entre os dois amantes, continuamente, haverá um terceiro elemento, real ou imaginário a compor esse triângulo. Segundo Girard, desde o instante em que há desejo,

\footnotetext{
${ }^{64}$ Egli guardò le fotografie: un vecchio che s'era fato fotografare in posa di grand'uomo, appoggiato a un fascio di carte. Emilio sorrise. - II mio santolo - presentò Angiolina. Un giovanotto vestito bene ma come un operaio in festa, una faccia energica, uno sguardo ardito. Il santolo di mia sorella, - disse Angiolina, - e questo è il santolo del più giovine dei miei fratelli, - e fece vedere il ritratto di un altro giovanotto più mite e più fine dell'altro. / - Ce ne sono degli altri? - domandò Emilio, ma lo scherzo gli morì sulle labbra perché tra le fotografie ne aveva scoperte due unite, di uomini ch'gli conosceva: Leardi e Sorniani! (...) / Angiolina non comprese subito perché la fronte di Emilio si fosse tanto oscurata. Per la prima volta, brutalmente, egli tradì la sua gelosia: - Non mi piace mica di trovare tanti uomini in questa stanza da letto -.(...) / Improvvisamente ella ebbe dipinta sulla faccia una grande ilarità, e dichiarò ch'era ben lieta di vederlo geloso. - Geloso di questa gente! - disse poi rifacendosi seria e con aria di rimprovero. Ibid., pp. 426-427.
} 
mesmo nos personagens mais apaixonados, como é o caso de Emilio Brentani, encontramos o mediador, um terceiro que se faz presente no momento do nascimento desse desejo (GIRARD, 1965, p.22). O ciúme de Emílio pode ser visto também, como um "sintoma" de sua insegurança, de sua baixa autoestima, características de seu caráter inapto.

Note-se que o "amigo" Sorniani também está presente entre as diversas fotos dos homens que figuram no humilde quarto de Angiolina. Os homens fotografados certamente tiveram alguma relação com a bela jovem, que não demonstra interesse em escondê-los do amante ciumento. Ela se diverte com a situação, sentindo prazer em perceber que Emilio já se encontra enredado por sua sedução. A base desse triângulo amoroso já se formou e seu ápice parece ter mais de um rival:

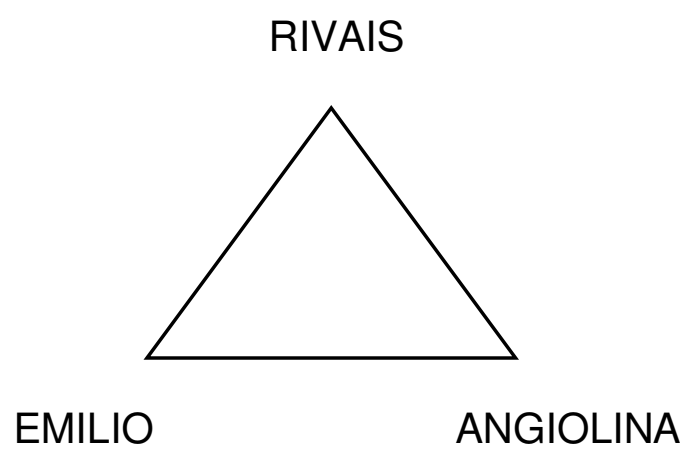

Como já foi ressaltado anteriormente, de acordo com a teoria postulada por René Girard, toda relação amorosa é triangular. O terceiro elemento que compõe um dos vértices do triângulo pode ser chamado de rival ou mediador. De acordo com Gabriel Andrade, em René Girard: un retrato intelectual, "o sujeito desejante necessita de um modelo que apoie sua decisão; nunca se 
atreve a desejar por conta própria" (ANDRADE, 2011, p.400). Assim, Emilio precisa saber que Angiolina é desejada, precisa de um modelo para se “inspirar" e consequentemente, desejá-la.

Os homens retratados e expostos no quarto da amante, aqueles, que a moça diz serem padrinhos de seus irmãos e dela, não são conhecidos de Emilio, assim, não existe uma relação próxima entre eles, consequentemente a mediação é a externa. Já a mediação entre Emilio e os outros dois homens (Leardi e Sorniani) pode ser classificada como interna, pois eles se conhecem. Veremos, porém, que há o predomínio da mediação interna, que se apresenta de modo mais intenso entre Emilio e seus rivais.

Toda narrativa do romance desenvolve-se a partir da relação entre Emilio Brentani e Angiolina Zarri, que, como dissemos, desde o início será triangular. O encontro entre os dois, já evidencia a cristalização do esquema do triângulo amoroso. A proposta de Emilio em viver um relacionamento casual com a moça dá indícios de que o relacionamento entre eles comportará um terceiro elemento, que será proposto, posteriormente, por Angiolina sem o menor pudor:

Emilio sentia uma satisfação completa com a posse incompleta daquela mulher, e só tentou ir além por desconfiança, com receio de ser escarnecido por todos aqueles que o observavam. Ela defendeu-se energicamente: seus irmãos a matariam. Chorou na vez em que ele foi mais agressivo. Não gostava dela se a queria fazer infeliz. Ele renunciou então àqueles avanços, apaziguado e satisfeito. Ela não pertencera a ninguém assim podia estar seguro de que não se ririam dele. Mas ela prometeu-lhe formalmente que seria sua quando pudesse entregar-se sem expô-lo a dificuldades nem causar danos a si própria. Falava disso como da coisa mais natural do mundo. Teve mesmo um achado: precisavam encontrar um terceiro sobre quem descarregar 
aquele incômodo, aquele dano e não poucas zombarias. Ele ficou a ouvir extasiado aquelas palavras que lhe soavam apenas como uma declaração de amor. Havia pouca esperança de encontrar aquele terceiro que Angiolina queria, mas depois dessas palavras ele acreditava poder acomodar-se tranquilo em seu próprio sentimento. Angiolina era de fato como ele queria que fosse, e dava-Ihe o amor sem vínculos, sem qualquer perigo.

$\mathrm{Na}$ verdade toda a sua vida agora pertencia àquele amor; não sabia pensar em mais nada, não sabia trabalhar, nem mesmo cumprir normalmente seus deveres de ofício. ${ }^{65}$ (SVEVO, 1982, p.44, grifo nosso)

O início do excerto é marcado pela antítese "satisfação completa com a posse incompleta daquela mulher". O jogo entre os adjetivos completa e incompleta denunciam o contraste, ou melhor, conflito, que fará parte da relação dos amantes. Impossível sentir uma satisfação completa se a posse não for plena. A antítese, aliás, marca a tônica do romance e aqui é um prenúncio da falta de plenitude na vida do inapto, Emilio Brentani, que insiste em viver uma realidade também incompleta, pois não consegue sair de seu frágil castelo de cristal para encarar a vida real que o rodeia. A própria condição vivida pelo protagonista, isto é, um "jovem senil”, evidencia a antítese como marca fundamental do romance.

\footnotetext{
${ }^{65}$ Eppure egli aveva una soddisfazione completa dal possesso incompleto di quella donna, e tentò di procedere oltre solo per diffidenza, per timore di venir deriso da tutti quegli uomini che lo guardavano. Ella si difese energicamente: i suoi fratelli l'avrebbero ammazzata. Pianse una volta in cui egli fu più aggressivo. Non le voleva bene se voleva renderla infelice. Allora egli rinunziò a quella aggressioni, racchetato, lieto. Ella non era appartenuta a nessuno ed egli poteva essere certo di non venir deriso. Peró ella gli promise formalmente che sarebbe stata sua quando si fosse potuta dare senza espor lui a fastidi né se stessa a danni. Ne parlava come della cosa più nautrale di questo mondo. Anzi ebbe una trovata: Bisognava cercare un terzo su cui scaricare questo disturbo, questo danno e non poche beffe. Egli stava ad ascoltare estatico queste che non gli parevano altro che dichiarazioni d'amore. C'era poca speranza di trovare quel terzo come lo voleva Angiolina, ma dopo queste parole egli credeva di poter adagiarsi tranquillo nel proprio sentimento. Ella era in verità come egli l'aveva voluta, e gli dava l'amore senza legami, senza pericolo. / Certo, per il momento tutta la sua vita apparteneva a quell'amore; non sapeva pensare altro, non sapeva lavorare, neppure adempiere per bene ai suoi doveri d'ufficio. Ibid., p. 430.
} 
As palavras iniciais ditas por Emilio sobre como seria a relação entre eles foram registradas pela amante, que consciente de que entre ela e Brentani jamais poderia existir um relacionamento sério, tem uma grande ideia para chamar Emilio à vida real, encontrar um amante. Só assim ela se entregaria a ele. Tal reflexão é para Emilio uma verdadeira declaração de amor, uma janela para o ciúme e, mais um "ataque" irônico do narrador com o protagonista.

A paixão que deveria trazer vitalidade, vigor a Emilio parece paralisá-lo, ele não consegue fazer mais nada além de fantasiar e idealizar uma relação e uma mulher, preanunciando a desilusão que se seguirá. Brentani parece querer fazer desse relacionamento uma grande história de amor nos moldes românticos, contudo o narrador não o perdoa e, diante de seus devaneios, usa de uma ironia ferina e cortante. Não demorará muito a Angiolina encontrar o terceiro elemento para compor essa relação; mais um rival para instigar o ciúme de Emilio:

- Estou noiva - disse ela, numa voz que tentava ser sentimental, rompida de súbito por uma enorme vontade de rir.

- Noiva! - murmurou Emilio por um instante incrédulo, tanto que logo começou a indagar-se a razão daquela mentira. Fitoua no rosto e, a despeito da obscuridade, viu em sua expressão o sentimentalismo que havia desaparecido de sua voz. Devia ser verdade. Com que intuito lhe contaria uma mentira? Teriam então encontrado o terceiro que andavam procurando! - Está satisfeito agora? - Está satisfeito agora? - perguntou ela carinhosa. ${ }^{66}$ (SVEVO, 1982, pp.47-48, grifo nosso)

\footnotetext{
${ }^{66}$ - Sono fidanzata - disse ella, nella você un tentativo di nota sentimentale, rotta subito da una grande voglia di ridere. / - Fidanzata! - mormorò Emilio per un istante incredulo tanto che subito si rivolse a indagare la ragione per cui ella gli diceva quella bugia. La guardò in faccia e, ad onta dell'oscurità, vide nell'atteggiamento la sentimentalità che dalla voce era scomparsa. Doveva essere vero. A quale scopo gli avrebbe raccontato una bugia? Avevano dunque trovato il terzo di cui abbisognavano! - Sarai contento ora? - domandò ella carezzevole. Ibid., p. 433.
} 
Note-se que o discurso de Angiolina é debochado; a jovem tenta imitar o sentimentalismo de Emilio, mas não consegue, a vontade de rir é maior. Um riso que diríamos ser também do comportamento tolo e ingênuo de Brentani, que se indaga por que motivo ela lhe contaria uma mentira. Angiolina é mais sincera, vive sua realidade sem se esconder atrás de um mundo fantasioso e ficcional; quem necessita enganar-se é, sem dúvida, Emilio.

É Angiolina quem tem a mirabolante ideia de encontrar esse terceiro para poder entregar-se a Brentani, cabe a ela, somente a ela, encontrar um outro e não a Brentani; sua inércia e sua dificuldade em ser pragmático e racional o impedem de agir. A postura da senhorita Zarri, encarregada pela postura de Brentani a assumir o papel de sedutora, ao invés de seduzida, se faz necessária para poder manter o relacionamento com Emilio e gozar dos benefícios do mesmo até que apareça uma oportunidade que the seja mais conveniente.

Outro exemplo de mediação externa, presente na narrativa, constitui-se no ciúme que o suposto noivo de Angiolina, o alfaiate Volpini, desperta em Emilio:

- E se Volpini souber deste nosso passeio pela cidade?

- Quem Ihe haveria de contar? - disse ela com grande calma. - Eu diria que você é irmão ou primo de Sra. Deluigi. Ele não conhece ninguém em Trieste; por isso é fácil fazê-lo acreditar seja no que for ${ }^{67}$. (SVEVO, 1982, p.56)

(...)

${ }^{67}$ (...) - E se Volpini risapesse di questa nostra passeggiata traverso la città? / - Chi gliel'avrebbe a dire? - disse essa con grande calma. - Gli direi che tu sei un fratello o un cugino della Deluigi. Egli non conosce nessuno a Trieste, ed è quindi facile fargli credere ciò che si vuole. Ibid., p. 439. 
Comovido, Emilio confessou-se. Sim. Agora o via claramente. A coisa tornava-se muito séria, e descreveu o próprio amor, a ansiedade de vê-la, de falar-lhe, os ciúmes, as dúvidas, a angústia incessante e o perfeito esquecimento de todas as coisas que não dissessem respeito a ela ou ao próprio sentimento. Depois falou sobre Angiolina como agora a julgava em consequência de seu comportamento na rua, daquelas fotos penduradas à parede de seu quarto e de seu sacrifício ao alfaiate e do pacto que fizeram. ${ }^{68}$ (SVEVO, 1982, pp.57-58, grifo nosso)

Tal passagem pode ser tomada como um claro exemplo do que vem a ser mediação externa, uma vez que não há contato entre Emilio e Volpini. Note-se que é explicito na relação dos amantes a presença de um terceiro. Brentani não tem coragem de assumir a moça, que lhe propõe sem pudores a possibilidade de tornar-se sua amante e viver um adultério. A configuração do triângulo amoroso seria:

\section{VOLPINI}

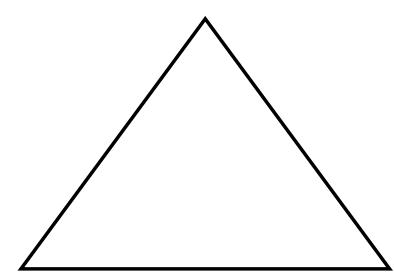

\section{EMILIO}

ANGIOLINA

Emilio está colocado na base ao lado de Angiolina, pois entre a bela e o alfaiate ainda não fora consumada nenhuma relação, contudo vale ressaltar

\footnotetext{
${ }^{68}$ Commosso, Emilio si confessò. Sì. Ora lo sentiva chiaramente. La cosa era divenuta per lui molto seria, e descrisse il proprio amore, l'ansietà di verderla, di parlarle, la gelosia, il dubbio, il cruccio incessante e l'oblio perfetto d'ogni cosa che non avesse avuto attinenza a lei o al proprio sentimento. Poi parlò d'Angiolina come ora la giudicava in seguito al contegno ch'ella teneva sulla via, alle fotografie appese al muro della sua stanza e alla sua dedizione al sarto e ai loro patti. Ibid., p. 441.
} 
que a mediação entre Brentani e Volpini sempre será externa, pois os dois não se conhecem.

Outro exemplo de mediação externa no romance pode ser visto a propósito do ciúme sentido por Emilio, ao perceber que Angiolina está flertando com os transeuntes desconhecidos da rua:

- Por que está flertando? - perguntou-lhe com um sorriso contrafeito.

Sem enrubescer e rindo-se, ela respondeu: - Eu? Tenho olhos para ver, não? (...)

Pouco depois passou um pequeno empregado, um certo Giustini, belo rapaz que Emilio conhecia de vista. O olhar de Angiolina reanimou-se e Emilio voltou para ver o feliz mortal que havia passado. O empregadinho estava parado a observálos. - Parou para olhar-me, não foi? - perguntou ela a Emilio, sorrindo satisfeita.

- Por que ficou tão satisfeita com isso? - perguntou ele com tristeza. Ela não conseguia compreender. Depois, com astúcia, quis fazê-lo acreditar que ela, de propósito, estava procurando despertar-Ihe ciúmes, e, por fim, para acalmá-lo, impudicamente, à luz do sol fez com os lábios rubros um gesto que queria representar um beijo. ${ }^{69}$ (SVEVO, 1982, p.55, grifo nosso)

Aqui, temos mais um modelo da mediação externa, pois é impossível haver contato entre Emilio e os homens com quem Angiolina flerta. Com exceção de Giustini, que Brentani parece conhecer e reconhecer sua beleza (típica e superior como a de todos os rivais descritos), não há uma relação

${ }^{69}$ - Perché civetti? - chiese egli costrigendosi ad un sorriso. / Senz'arrosire e ridendo, ella rispose: - lo? Ho gli occhi per guardare, io -. (...) / Poco dopo passò un impiegatuccio, certo Giustini, bel giovinetto che Emilio conosceva di vista. L'occhio di Angiolina si ravvivò ed Emilio si volse a guardare il fortunato mortale ch'era già passato. L'impiegatuccio s'era fermato a guardarli. - S'è fermato a guardarmi, eh? - chiese essa sorridendo lieta. / - Perché te ne compiaci? - chiese egli con tristezza. Ella non lo comprese neppure. Poi, con astuzia, volle fargli credere ch'ella, di proposito, cercasse di renderlo geloso, e, infine, per quietarlo, spudoratamente, alla luce del sole, fece con le labbra rosse una smorfia che voleva rappresentare un bacio. Ibid., p. 439. 
mais próxima entre o protagonista e os outros rivais, homens desconhecidos que caminham na mesma rua em que os amantes. Todavia, mais um triângulo amoroso é constituído:

GIUSTINI (MEDIAÇÃO INTERNA)

TRANSEUNTES (MEDIAÇÃO EXTERNA)

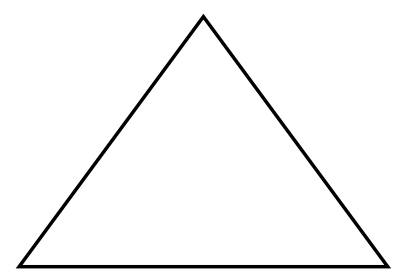

EMILIO

ANGIOLINA

Certamente, como se pode notar pela instância da narrativa, o senhor Brentani não conhece bem tais homens, contudo sente ciúme deles. Esses exemplos de mediação externa são importantes ainda, por nos revelar o caráter de Angiolina, reforçando a premissa de que a Ange idealizada por Brentani, de fato, não passa de uma invenção sua.

Emilio tem clara consciência de que entre a Angiolina real e a Ange, sua criação, existe um abismo muito grande. As duas "Angiolinas" coexistem lado a lado no mundo ficcional de Brentani, que se esforça exaustivamente em transformar a Angiolina real em um personagem de seu conto de fadas, vivente em um mundo virtual. A amante mais uma vez demonstra divertir-se com o comportamento de Emilio e não coopera em nada com essa transformação delirante, pois reconhece e aceita sua verdadeira índole, que lhe convém, pois 
Ihe permite usufruir da situação. Emilio, ao contrário, busca, o tempo todo, criar mecanismos para se enganar e para esconder seu caráter débil.

Diferentemente da mediação externa, em que há certo distanciamento entre o sujeito-desejante e o mediador ou rival, cuja relação não é de amizade ou de meros conhecidos, na mediação interna há maior contato entre sujeito e rival. Esse tipo de mediação pode ser visto na relação próxima e afetuosa de Emilio e Balli.

O senhor Brentani, antes de apresentar a bela Angiolina ao amigo, mantém um relacionamento confidente com o escultor, contando os pormenores de seu relacionamento com a amante. Balli, que incialmente, atuará como uma espécie de modelo para Emilio, que, por sua vez, deseja imitá-lo em alguns momentos, passará aos poucos a ser o rival na relação do amigo e da bela Angiolina.

Assim como Macario, verdadeiro e vigoroso rival de Alfonso Nitti, Stefano Balli é apresentado com atributos bem mais interessantes do que o protagonista:

Balli, ao contrário, havia empregado melhor os seus quarenta anos bem vividos, e sua experiência o tornava competente para julgar o amigo. Era menos culto, mas sempre exercera sobre o outro uma espécie de autoridade paterna, consentida, desejada por Emilio, o qual, apesar de seu destino pouco risonho, mas em absoluto ameaçador, e de sua vida em que nada havia de imprevisto, precisava de apoio para sentir-se seguro.

Stefano Balli era um homem alto e forte, de olhos azuis de criança numa dessas faces de aspecto bronzeado que nunca envelhecem: o único traço da idade era o grisalho dos cabelos castanhos, a barba aparada com precisão, toda a figura muito correta e um tanto dura. Era por vezes doce o seu olhar de observador quando o animava a curiosidade ou a compaixão, 
mas tornava-se duríssimo na luta ou nas discussões mais fúteis. ${ }^{70}$ (SVEVO, 1982, p.19)

Balli, apesar de ser menos culto, sabe aproveitar a vida, além de ser descrito como um belo homem, o que é suficiente para desestabilizar o amigo Brentani. Além da caracterização física superior, Stefano tem uma qualidade, muito desejada e até invejada por Emilio, a capacidade do escultor em seduzir as mulheres, que, na maioria das vezes, apaixonam-se por ele. $\mathrm{O}$ desejo de Emilio por Angiolina, segundo a teoria girardiana, "está, desde o princípio, dilacerado entre o eu e um outro que sempre parece mais soberano, mais autônomo que o eu" (GIRARD, 2011, p.13). Esse outro pode ser visto na figura do amigo e futuro rival, Stefano Balli. Logo após o primeiro encontro com a senhorita Zarri, Emilio procura, entusiasmado, o escultor para contar o acontecido:

\begin{abstract}
Seu amigo mais íntimo, um certo Balli, escultor, soube do encontro logo no dia seguinte em que ocorrera. - Por que também não me divertir um pouco, se o posso fazer sem gastar muito? - perguntara Emilio.
\end{abstract}

Balli esteve a ouvi-lo com um aspecto evidentemente maravilhado. Era amigo de Brentani há mais de dez anos, e pela primeira vez o via empolgar-se por uma mulher. Ficou preocupado ao perceber o perigo que ameaçava Brentani. ${ }^{71}$ (SVEVO, 1982, pp.18-19)

\footnotetext{
70 II Balli invece aveva impiegati meglio i suoi quarant'anni sonati, e la sua esperienza lo rendeva competente a giudicare di quella dell'amico. Era meno colto, ma aveva sempre avuto su lui una specie d'autorità paterna, consentita, voluta da Emilio, il quale, ad onta del suo destino poco lieto ma per nulla minaccioso, e della sua vita in cui non v'era niente di imprevisto, abbisognava di puntelli per sentirsi sicuro. / Stefano Balli era un uomo alto e forte, l'occhio azzurro giovanile su una di quelle faccie dalla cera bronzina che non invecchiano - unica traccia della sua età la brizzolatura dei capelli castani - la barba appuntata con precisione, tutta la figura corretta e un po' dura. Era talvolta dolce il suo occhio da osservatore quando lo animava la curiosità e la compassione, ma diveniva durissimo nella lotta e nella discussione più futile. Ibid., pp. 409-410.

${ }^{71}$ II suo più intimo amico, un certo Balli, scultore, seppe dell'incontro subito il giorno dopo ch'era avvenuto. - Perché non potrei divertirmi un poco anch'io, quando posso farlo tanto a buon
} 
Tal passagem é importante por evidenciar a intensidade e a extensão da amizade entre Emilio e Balli. A relação harmoniosa que existe entre eles será balançada depois que Emilio apresentar Angiolina ao escultor. Nesse momento, o senhor Brentani começa a dar mostras do ciúme que sente do amigo:

- Que mau gosto! - exclamou Balli sem poder deixar de rir. Percebia-se que a partir desse instante Angiolina o divertia muito. Ele continuou a dizer-Ihe coisas desagradáveis, mas parecia fazê-lo apenas para incitá-la a defender-se. Ela também se divertia com isto. Havia em seu olhar para o escultor a mesma benevolência que brilhava no de Margherita; uma mulher copiava a outra, e Emilio, depois de tentar em vão introduzir algumas palavras na conversa geral, estava agora propenso a perguntar-se por que motivo organizara essa noitada. ${ }^{72}$ (SVEVO, 1982, p.69, grifo nosso)

A noitada que deveria ser de alegria, de prazer termina por causar arrependimento em Emilio, que pretendia mostrar ao amigo sua capacidade em conquistar uma bela moça, contudo esqueceu-se de que o amigo era mestre nessa arte, e sempre fazia muito sucesso com o sexo oposto. Note-se, pelos termos grifados, que o senhor Brentani se sente excluído, e percebe que Angiolina se interessa pelo amigo. Emilio começa a sentir ciúmes,

mercato? - aveva chiesto Emilio. / II Balli stette a udirlo con l'aspetto più evidente della meraviglia. Era l'amico del Brentani da oltre dieci anni, e per la prima volta lo vedeva accalorarsi per una donna. Se ne impensierì scorgendo subito il pericolo da cui il Brentani era minacciato. Ibid., p. 409.

72 - Che cattivo gusto! - esclamò il Balli non potendo però tenersi dal ridere. Si capì che dal quel momento Angiolina lo divertì molto. Continuò a dirle delle cose sgradevoli ma pareva lo facesse per provocarla a difendersi. Ella stessa ci si divertiva. Nel suo occhio c'era per lo scultore la medesima benevolenza che brillava in quello di Margherita; una donna copiava l'altra, ed Emilio, dopo aver cercato invano di cacciare qualche parole nella conversazione generale, era ora intento a domandarsi perché avesse organizzata quella adunanza. Ibid., p. 451. 
principalmente quando o amigo convida à senhorita Zarri a posar como modelo para uma escultura:

Balli agradeceu e disse que certamente se aproveitaria da oferta, mas somente dali a alguns meses, pois, por ora, estava muito ocupado em outros trabalhos. Fitou-a longamente, imaginando a pose em que a teria retratado, e Angiolina ficou rubra de prazer. Ah, se pelo menos Emilio tivesse um parceiro no sofrimento. Mas, não! Margherita não era de modo algum ciumenta, e também contemplava Angiolina com olhar de artista. Disse que Stefano haveria de fazer um belo trabalho, contando com entusiasmo as surpresas que sua arte Ihe havia proporcionado, ao vê-lo extrair da argila dócil uma face, uma expressão, a vida. ${ }^{73}$ (SVEVO, 1982, pp.72-73, grifo nosso)

Após esse encontro, a relação entre Emilio e Balli é estremecida, a estreita amizade cede lugar à insegurança e, consequentemente, aos ciúmes de Emilio, que se distancia do escultor. O trecho mostra a primeira crise de ciúmes de Brentani pelo amigo, neste momento a relação ganha novo rival e o triângulo amoroso outra configuração:

\section{BALLI}

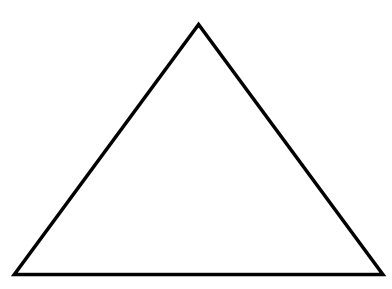

EMILIO

ANGIOLINA

\footnotetext{
${ }^{73}$ |l Balli ringraziò e disse che ne avrebbe sicuramente approfittato, ma soltanto di là a qualche mese, perché, per il momento, era troppo occupato con altri lavori. La guardò lungamente sognando la posa in cui l'avrebbe ritratta e Angiolina divenne rossa dal piacere. Almeno Emilio avesse avuto un compagno di sofferenza. Ma no! Margherita non era affatto gelosa, e guardava Angiolina anche lei con l'occhio d'artista. Stefano ne avrebbe fatta una cosa bella, disse, e parlò con entusiasmo delle sorprese che le aveva date l'arte, quando dall'argila docile usciva una faccia, un'espressione, la vita. Ibid., p. 409.
} 
Entre os tantos rivais de Emilio, a nosso ver, Balli será o que mais causará desconforto em Brentani, que sabe que o amigo já despertara o interesse de sua amante. Stefano, em comparação aos outros rivais, é mais "real", não é fruto da imaginação fértil de Emilio, consequentemente representa uma ameaça maior a ele, daí o ciúme e, também, o grande sentimento de inferioridade de Emilio, típico de seu caráter inapto. A suspeita do amigo possuir Angiolina o tortura. Brentani reconhece seu temperamento ciumento, e confessa seu grande temor de uma aproximação entre o escultor e a amante:

- Tem ciúmes de mim, imagine só, de seu melhor amigo! urrou Balli indignado. ${ }^{74}$ (SVEVO, 1982, p.81, grifo nosso)

- Contudo - confessou Emilio sinceramente comovido com o afeto de Balli -, nunca sofri tanto de ciúme quanto agora. Parando em frente de Stefano, disse-lhe com voz profunda: Promete que vai contar-me tudo quanto souber a respeito dela? Não quero que você se aproxime dela, mas se a vir na rua venha logo contar-me. Promete? Promete formalmente? ${ }^{75}$ (SVEVO, 1982, p.128, grifo nosso)

Balli tem uma atitude de indignação, que nos parece irônica, pois não pode acreditar que Brentani sente ciúmes dele, com "aquela" moça, já que se considera melhor amigo de Emilio. Brentani, porém, tem ciúmes da sua criação, da sua Ange e conhece a fama de sedutor de Stefano que goza de grande sucesso com as mulheres. Diante disso, Emilio demonstra-se ainda mais fraco e implora ao amigo para ficar longe de sua amante.

\footnotetext{
${ }^{74}$ - È geloso di me, capisce, del suo miglior amico! - urlò il Balli indignato. Ibid., p. 461.

75 - Eppure - confessò Emilio sinceramente commosso dall'affetto del Balli -, non ho mai sofferto tanto di gelosia quanto ora -. Fermandosi in faccia a Stefano, gli disse con voce profonda: - Promettimi che tu mi racconterai sempre quanto sul conto suo apprenderai; ma tu non l'avvicinerai mai, mai e se la vedessi sulla via me lo racconteresti subito. Promettimelo formalmente. Ibid., p. 501.
} 
As crises de ciúme de Emilio percorrem toda a narrativa. Tal sentimento atua como uma espécie de fio condutor que impulsiona a narração, conectando as diversas situações vivenciadas por Brentani. Além de atuar como um mecanismo propulsor, essencial para a compreensão da história dos amantes, o ciúme constitui-se em uma das chaves de leitura para maior entendimento do protagonista. Ao lado de seu caráter inapto, que será analisado posteriormente, encontra-se seu lado ciumento que nos permite um olhar sobre o verdadeiro Emilio, o qual ao lado da vital Angiolina, busca encenar uma história fantasiosa.

Em várias passagens da narrativa, Emilio declara e confessa esse sentimento nefasto que atormenta sua existência; Brentani tem consciência de estar "doente de ciúmes, apenas de ciúmes"76 (SVEVO, 1982, p.129). Ao admitir este sentimento em relação a Angiolina, Emilio enfraquece-se enquanto ela fortalece-se, e usa tal confissão a seu favor, estimulando ainda mais o ciúme do amante, que provocara desde o início da relação, e divertindo-se com isso.

A possível e real concretização de um envolvimento entre Stefano e Angiolina causa em Emilio um grande sofrimento e, o leva a afirmar, com todas as letras, que se Balli não existisse, sua relação com Angiolina seria mais harmoniosa:

Por desgraça, Emilio, ao voltar para a cama, não conseguiu novamente pegar no sono. Recordava com amargura o modo como Balli se vangloriava dos amores que despertava e como, com um sorriso de pessoa satisfeita, dizia que o único êxito que lhe faltava na vida era o sucesso artístico. Depois na longa

\footnotetext{
${ }^{76}$ Sabemos que o tema da doença (malattia) é recorrente na obra de Italo Svevo, contudo nossa leitura não pretende analisar o ciúme como uma patologia.
} 
sonolência em que tombou, teve sonhos absurdos. Balli abusava da submissão de Amalia e recusava-se sorrindo a assumir responsabilidades. Quando voltou a si, o sonhador não achou graça nesses sonhos. Entre um homem tão corrupto como Balli e uma mulher tão ingênua quanto Amalia, tudo seria possível. Resolveu empreender a cura da irmã. Começaria por afastar de casa o escultor, que desde algum tempo, embora sem culpa sua, se havia convertido em portador de desventura. Se não fosse ele, seu relacionamento com Angiolina teria sido mais suave, não complicado por ciúmes tão amargos. $^{77}$ (SVEVO, 1982, pp.131-132, grifo nosso)

Estava mesmo firmado pelo destino que Balli haveria sempre de intervir para tornar mais dolorosa a situação de Emilio em face de Angiolina. ${ }^{78}$ (SVEVO, 1982, p.191, grifo nosso)

A possibilidade da traição do amigo com sua Ange passa a atormentar Emilio até em seus sonhos, em que visualiza histórias absurdas com o escultor e sua irmã. Incapaz de sonhar com o amigo Balli e Angiolina, Emilio sonha com a irmã no lugar de sua amante, e agarra-se ao conteúdo onírico para empreender a cura da irmã que consiste em afastar Balli do convívio entre eles. A irmã, aqui, é usada como um álibi para Brentani fugir à sua realidade.

Tais passagens levam ainda ao questionamento se, de fato, a relação de Emilio e Angiolina seria mais suave sem a existência de Balli. A própria narrativa nos permite afirmar que não. Se não fosse Balli a ocupar o terceiro

\footnotetext{
${ }^{77}$ Fu una sventura ch'Emilio, ricoricatosi, non pigliasse sonno. Ricordava con amarezza come il Balli si vantasse degli amori ch'egli destava e come, con un sorriso di persona soddisfatta, dicesse che l'unico successo che gli mancasse nella vita era il successo artistico. Poi, nel lungo dormiveglia in cui piombò, feci dei sogni assurdi. II Balli abusava della sommissione d'Amalia, e rifiutava ridendo qualsiasi riparazione. II sognatore, ritornato in sé, non derise se stesso per quei sogni. Fra un uomo tanto corrotto come il Balli e una donna tanto ingenua come Amalia, tutto era possibile. Risolve d'imprendere la guarigione d'Amalia. Avrebbe incominciato coll'allontanare di casa lo scultore, il quale, da qualche tempo, benché senza sua colpa, era divenuto apportatore di sventura. Se non ci fosse stato lui, la relazione con Angiolina sarebbe stata più dolce, non complicata da tanta amara gelosia. In SVEVO, Italo. Romanzi e "continuazioni". Milano: Mondadori, 2006, p. 504.
}

\footnotetext{
${ }^{78}$ Era proprio stabilito dal destino che il Balli dovesse sempre intervenire a rendere più dolorosa la situazione di Emilio in faccia ad Angiolina. Ibid., p. 554.
} 
vértice desse triângulo amoroso, certamente, haveria outro, pois não só o ciúme é intrínseco à natureza do senhor Brentani, que sempre será atormentado com a possibilidade da traição, mas também o comportamento de Angiolina parece querer instigá-lo a esse sentimento, com sua ação um tanto duvidosa. Todavia, o desejo de Emilio por Angiolina é mais forte, e conforme a teoria de Girard, enquanto houver desejo, haverá um rival e uma relação triangular.

Mesmo após o doloroso término com Angiolina, impulsionado mais pela doença da irmã que pela descoberta da índole da amante, Emilio não conseguirá esquecê-la. Se no plano físico há separação entre os amantes, no mental Emilio imortalizará a beleza da moça e a nostalgia que sente da mesma. "Angiolina sofreu uma metamorfose estranha. Conservou inalterada a beleza, mas adquiriu ainda todas as qualidades de Amalia..."79 (SVEVO, 1982, p.267). Mais uma vez, Emilio usa de subterfúgios para idealizar e imortalizar a bela "criatura" que ele construíra ficcionalmente no passado, e ao qual ele ficará aprisionado, sem conseguir viver o presente, entregando-se a uma triste e solitária senilidade existencial nel mezzo del cammin de sua vida.

\footnotetext{
${ }^{79}$ Angiolina subì una metamorfosi strana. Conservò inalterata la sua belezza, ma acquistò anche tutte le qualità d'Amalia... Ibid., p. 620.
} 


\subsection{La Coscienza di Zeno: ciúme e posse em cena}

No terceiro romance de Svevo, La coscienza di Zeno, o ciúme apresenta-se de forma mais diluída, leve e com um tom que está entre o humor e a ironia. Zeno Cosini, assim como Alfonso e Emilio, também experimenta tal sentimento, contudo o vivencia de forma mais madura e equilibrada. Cosini, ao contrário de seus irmãos mais novos: Alfonso e Emilio, consegue tirar proveito dos prazeres da vida; mesmo aos 57 anos, confessa sentir um imenso desejo pelo sexo oposto:

(...) Contei-lhe sobre o meu problema com as mulheres. Uma só não me bastava, nem mesmo muitas. Queria-as todas! Pelas ruas, minha excitação era enorme: à medida que passavam, as mulheres eram minhas. Olhava-as com insolência pela necessidade de sentir-me mal. No pensamento despia-as todas, deixando-as apenas de sapatos, tomava-as nos braços e só as soltava quando tinha certeza de conhecêlas bem. ${ }^{80}$ (SVEVO, 2006, p.23)

(...) Tenho 57 anos e estou certo de que se não deixar de fumar ou se não for curado pela psicanálise, em meu leito de morte meu último olhar será de desejo pela minha enfermeira, se esta não for minha mulher e se minha mulher tiver permitido que ela seja bela!

Fui sincero como se me confessasse... ${ }^{81}$ (SVEVO, 2006, p.24)

Diferentemente dos outros romances, que são narrados em $3^{\text {a }}$ pessoa, aqui temos uma narrativa em $1^{1}$ a pessoa, por isso devemos estar atentos aos

\footnotetext{
${ }^{80}$ (...) Gli raccontai della mia miseria con le donne. Una non mi bastava e molte neppure. Le desideravo tutte! Per istrada la mia agitazione era enorme: come passavano, le donne erano mie. Le squadravo con insolenza per il bisogno di sentirmi brutale. Nel mio pensiero le spogliavo, lasciando loro gli stivaletti, me le recavo nelle braccia e le lasciavo solo quando ero ben certo do conoscerle tutte. Ibid., p. 636.

${ }^{81}$ (...) Ne ho cinquantasette degli anni e sono sicuro che se non cesso di fumare o che la psicoanalisi non mi guarisca, la mia ultima occhiata dal mio letto di morte sarà l'espressione del mio desiderio per la mia infermiera, se questa non sarà mia moglie e se mia moglie avrà permesso che sia bella! / Fui sincero come in confessione... Ibid., p. 637-638.
} 
"perigos" do texto, às mentiras que serão acumuladas por nosso narrador em uma história autobiográfica e que é escrita por "encomenda" de seu misterioso psicanalista, o Dr. S.. A maturidade do protagonista permite-Ihe confessar, sem receios, que seu último desejo será pela enfermeira, desde que esta seja bela. Nem mesmo em seu próprio leito de morte, Zeno deixará de sentir desejo e, consequentemente, compor um triângulo amoroso.

As relações triangulares farão parte da vida do protagonista; sempre existirá um rival a desejar o mesmo objeto que ele. Na juventude seu desejo se voltará rapidamente pela bela Ada Malfenti, cuja caracterização assemelhase a de Annetta e de Angiolina:

Entraram finalmente Ada e Alberta. Respirei: eram de fato bonitas e traziam à sala a luz que até então lhe faltara. Ambas morenas, altas e esbeltas, mas muito diferentes uma da outra. A escolha que eu devia fazer nada tinha de difícil. Alberta não contava então mais que dezessete anos. (...) Ada, ao contrário, já era mulher, com seus olhos sérios numa face que chegava a ser azulada de tão nívea, emoldurada por uma espessa cabeleira, encaracolada, embora disposta com graça e rigor. ${ }^{82}$ (SVEVO, 2006, p.78, grifo nosso).

É difícil remontar à doce origem de um sentimento que se tornou depois tão violento, mas estou certo de que não experimentei por Ada o que se costuma chamar de paixão à primeira vista. Assim mesmo, tive imediatamente a convicção de que era ela a mulher de quem eu precisava para assegurarme a saúde moral e física por meio de uma santa monogamia. ${ }^{83}$ (SVEVO, 2006, pp.78-79, grifo nosso)

${ }^{82}$ Entrarono finalmente Ada e Alberta. Respirai: erano belle ambedue e portavano in quel salotto la luce che fino ad allora vi aveva mancato. Ambedue brune e alte e slanciate, ma molto differenti l'una dell'altra. Non era una scelta difficile quella che avevo da fare. Alberta aveva allora non più di diciasett'anni. (...) Ada, invece, era già una donna con i suoi occhi serii in una faccia che per essere meglio nivea era un poco azzurra e la sua capigliatura ricca, ricciuta, ma accomodata con grazia e serenità. Ibid., p. 697.

${ }^{83}$ È difficile di scoprire le origini miti di un sentimento divenuto poi tanto violento, ma io sono certo che da me mancò il cosidetto coup de foudre per Ada. Quel colpo di fulmine, però, fu sostituito dalla convinzione ch'ebbi immediatamente che quella donna fosse quella di cui abbisognavo e che doveva addurmi alla salute morale e fisica per la santa monogamia. Ibid., p. 698. 
A beleza e vitalidade de Ada Malfenti impressionam Zeno; não se trata de um amor à primeira vista, mas de um desejo ao primeiro olhar, que é despertado pela beleza física. Ada exerce em Zeno um fascínio físico semelhante ao que Angiolina exercera em Emilio. Ele vislumbra em Ada a mulher perfeita para lhe assegurar a saúde moral e física, mantidas por intermédio de uma santa monogamia. A jovem encanta Zeno que tentará conquistá-la:

Parti assim na conquista de Ada e continuei sempre no proposito de fazê-la rir-se de mim ou à minha custa, sem lembrar que a havia escolhido por sua seriedade. Não deixo de ser um tanto estranho, mas devo ter-Ihe parecido perfeitamente desequilibrado. ${ }^{84}$ (SVEVO, 2006, p.79, grifo nosso)

Zeno decide usar o humor para conquistar a mulher desejada, contudo esquece que a escolhera por sua seriedade, assim a postura divertida e fanfarrona de Cosini não consegue atingir seu alvo, que se tornará uma ideia fixa em sua mente:

(...) A moça [Ada] não me saia da mente o dia inteiro. Era a mulher que eu havia escolhido, já portanto minha e adornei-a com todos os predicados para que o prêmio da vida me parecesse mais belo. Emprestei-lhe todas as qualidades de que sentia falta, para que, além da minha companheira, ela fosse também uma espécie de segunda mãe que me conduzisse por uma vida íntegra, viril, de lutas e conquistas. ${ }^{85}$ (SVEVO, 2006, pp.85-86, grifo nosso)

\footnotetext{
${ }^{84}$ Partii così alla conquista di Ada e continuai sempre nello sforzo di farla ridere di me e alle spalle mie dimenticando ch'io l'avevo prescelta per la sua serietà. lo sono un po' bizzarro, ma a lei dovetti apparire veramente squilibrato. Ibid., p. 699.

${ }^{85}$ (...) Essa [Ada] ben prestò m'accompagnò il giorno intero. Era la donna da me prescelta, era perciò già mia ed io l'adornai di tutti i sogni perché il premio della vita m'apparisse più bello. L'adornai, le prestai tutte le tante qualità di cui sentivo il bisogno e che a me mancavano, perché essa doveva divenire oltre che la mia compagna anche la mia seconda madre che m'avrebbe addotto a una vita intera, virile, di lotta e di vittoria. Ibid., p. 705.
} 
Note-se que o pensamento de Zeno está concentrado na bela moça, contudo isso não chega a paralisá-lo totalmente, como ocorrera com Emilio Brentani. Cosini também parece usar da imaginação, do elemento ficcional para caracterizar a pretendente, já que busca adorná-la de qualidades essenciais ao seu bem estar, para que a moça seja além da esposa, a companheira e a "segunda mãe". Aqui temos uma clara alusão crítica, já que o tom é irônico, à teoria psicanalítica, em especial, ao chamado complexo de Édipo, no qual o filho deseja relacionar-se com a mãe.

Zeno, a exemplo dos outros protagonistas, também é um inapto e como tal, divagará em seus pensamentos, reflexões e fantasias. Semelhante ao comportamento de Emilio Brentani, ele parece criar uma mulher cuja caracterização foge um pouco à realidade:

Envergonho-me de não haver percebido antes que caminhava para um malogro. Ada era uma criatura inteiramente ingênua, mas na imaginação eu a transformara numa namoradeira das mais consumadas. Daí ter sido totalmente injusto meu enorme rancor quando ela afinal me fez compreender que não queria nada comigo. Eu tanto havia confundido o sonho com a realidade que não conseguia convencer-me de que ela jamais me tivesse beijado. ${ }^{86}$ (SVEVO, 2006, p.87, grifo nosso)

A senhorita Malfenti é ingênua e séria, todavia Zeno quer transformá-la em uma moça namoradeira, assim como a senhorita Zarri era. Contudo, entre Ada e Angiolina as semelhanças restringem-se à mesma inicial do nome e a

\footnotetext{
${ }^{86} \mathrm{Mi}$ vergogno anche di non essermi accorto a tempo ch'ero avviato ad un fiasco simile. Avevo da fare con una fanciulla delle più semplici e fu a forza di sognarne ch'essa m'apparì quale una civetta delle più consumate. Ingiusto quell'enorme mio rancore quand'essa riuscì a farmi vedere ch'essa di me non ne voleva sapere. Ma io avevo mescolato tanto intimamente la realtà ai sogni che non riuscivo a convincermi ch'essa mai m'avesse baciato. Ibid., p. 707.
} 
beleza física. Se Emilio pretendia angelizar sua amante, Zeno, em contrapartida, sinaliza a vontade de realizar o processo inverso, ou seja, o de profanar a mulher.

Sonho e realidade misturam-se e confundem Zeno, cujo desejo por Ada parece intensificar. Forçado a se afastar por um tempo da casa Malfenti, a pedido da matriarca da família, Zeno dá asas à imaginação e entra em contato com seu ciúme:

Durante esses dias de segregação, o ciúme mais doentio foi meu companheiro de todas as horas. Era um propósito heroico querer corrigir-me de todos os defeitos naquela preparação para conquistar Ada ao fim de algumas semanas. $E$ enquanto isso? Enquanto me sujeitava à mais dura constrição, haveriam de estar tranquilos os outros cavalheiros da praça, ou estariam buscando uma forma de me roubar a dama? Devia haver certamente entre eles algum que não precisava de tanto exercício para ser bem recebido. Eu sabia, ou julgava saber, que, quando Ada encontrasse alguém que lhe servisse, haveria facilmente de se deixar enamorar. Quando, em tais dias, eu cruzava por algum senhor bem-vestido, bem-posto e sereno, odiava-o porque o achava digno de Ada. Desses dias, o que mais recordo é o ciúme, baixado como uma névoa sobre a minha vida. ${ }^{87}$ (SVEVO, 2006, pp.103-104, grifo nosso)

O protagonista descreve seu ciúme, caracterizando-o como doentio ou como uma névoa que encobre sua vida, sendo que tal descrição difere da encontrada em Una vita ou Senilità. Nos outros romances o ciúme é

\footnotetext{
${ }^{87}$ Durante quei giorni di segregazione la gelosia più amara fu la mia compagna di tutte le ore. Era un proposito eroico quello di voler correggersi di ogni difetto per prepararsi a conquistare Ada dopo qualche settimana. Ma intanto? Intanto ch'io m'assoggettavo alla più dura constrizione, si sarebbero tenuti tranquilli gli altri maschi della città e non avrebbero cercato di portarmi via la mia donna? Fra di loro v'era certamente qualcuno che non aveva bisogno di tanto esercizio per essere gradito. lo sapevo, io credevo di sapere che quando Ada avesse trovato chi faceva al caso suo, avrebbe subito consentito senza attendere di innamorarsi. Quando in quei giorni io m'imbattevo in un maschio ben vestito, sano e sereno, l'odiavo, perché mi pareva facesse al caso di Ada. Di quei giorni, la cosa che meglio ricordo è la gelosia che s'era abbassata come una nebbia sulla mia vita. Ibid., p. 726.
} 
representado como um sentimento amargo, angustiante e, muitas vezes, paralisante. Aqui o tom imprime ao ciúme certo humor, gerado pelo discurso caricato de Zeno ao imaginar seu objeto de desejo casando-se com um homem que ele "escolhera". Importante ressaltar que o olhar e postura de Zeno são diferentes, pois temos uma narrativa em $1^{1}$ a pessoa, na qual o protagonista nos conta sobre seu passado, época em que ele era mais jovem e que já se passara.

Em contrapartida, as histórias de Alfonso Nitti e Emilio Brentani são contadas no momento em que ocorriam, o que dá impressão de maior intensidade dos fatos e das emoções. Zeno narra uma história da qual ele já conhece o desfecho, pois já vivenciou tais momentos, sendo que 0 distanciamento de seu passado lhe permite amenizar e imprimir um matiz diverso sobre os acontecimentos narrados.

A imaginação de Zeno encarrega-se de encontrar um rival imaginário para compor o triângulo e duelar a conquista da jovem. Todavia não demorará a aparecer seu verdadeiro e maior rival, o senhor Guido Speier:

Ada não fez nenhum sinal. Com um sorriso espontâneo que Ihe modificou ligeiramente o desenho da face, e também o brilho do olhar, disse, estendendo-lhe a mão:

- Ah! O Sr. Guido!

O prenome me fez mal: ela, pouco antes, me chamara pelo nome de família. ${ }^{88}$ (SVEVO, 2006, p. 111, grifo nosso)

\footnotetext{
${ }^{88} \mathrm{Ma}$ Ada non fece quel segno. Con un sorriso spontaneo perché mutava lievemente il disegno delle guancie e della bocca ma anche la luce dell'occhio, ella gli stese la mano: - II signor Guido! / Quel prenome mi fece male. Ella, poco prima, mi aveva chiamato col nome mio di famiglia. Ibid., p. 734.
} 
A reação de Ada ao ver Guido mostra que ela não apenas o conhece, mas parece estimá-lo muito. Zeno percebe o interesse de sua amada pelo rival e sente-se mal por isso. Neste momento, já temos a configuração da relação triangular:

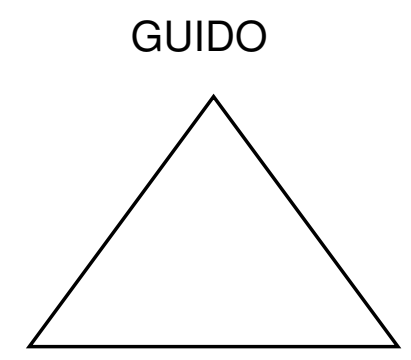

Zeno luta pelo amor de Ada, que ama Guido, seu rival. Como há contato entre o senhor Cosini e o senhor Speier o tipo de mediação existente entre eles, é a interna. Assim como todo rival, a descrição física do senhor Speier é relessalta:

Examinei o Sr. Guido. Vestia-se com rebuscada elegância e trazia na mão direita enluvada uma bengala com imenso castão de marfim, que eu não seria capaz de usar ainda que me pagassem bom dinheiro por quilômetro percorrido. ${ }^{89}$ (SVEVO, 2006, p.111, grifo nosso)

\section{$(\ldots)$}

Fitava-o para compreender melhor o que dizia. Era um rapaz de muito boa aparência: os lábios naturalmente entreabertos deixavam ver uma boca de dentes brancos e perfeitos. Seus olhos eram vivazes e expressivos e, quando tirou o chapéu, pude ver que seus cabelos escuros e um pouco anelados cobriam todo o espaço que a mãe natureza lhes havia

\footnotetext{
${ }^{89}$ Guardai meglio quel signor Guido. Era vestito con un'eleganza ricercata e teneva nella destra inguantata un bastone dal manico d'avorio lunghissimo, che io non avrei portato neppure se m'avessero pagato per ciò una somma per ogni chilometro. Ibid., p. 734.
} 
destinado, ao passo que uma boa parte da minha cabeça já fora invadida pela fronte. ${ }^{90}$ (SVEVO, 2006, pp.111-112, grifo nosso)

Como já foi destacado o rival, de acordo com Girard, sempre se apresenta mais soberano que o sujeito-desejante (GIRARD, 2011, p.13). A caracterização de Guido aponta essa soberania física, que nos remete a descrição de um verdadeiro herói medieval. Zeno e Guido disputam o mesmo objeto de desejo, Ada, que já fizera sua escolha. O senhor Speier, pelo que nos é contado pelo protagonista, jamais desconfiará do interesse de Zeno por Ada. Contudo a relação entre esses três personagens sempre será triangular, ainda que nunca haja lugar para uma relação, que não seja fraternal entre Ada e Zeno, a vida de tais personagens se interseccionam. Guido terá em Zeno um amigo; Ada verá em Zeno um irmão, contudo o senhor Cosini jamais deixará de nutrir desejo por Ada e ódio por Guido, seu eterno rival.

Zeno ainda tenta inutilmente conquistar Ada, mas todas suas tentativas são frustradas e, a última delas deixa marcas no senhor Cosini:

- Ada! Esse homem também não é para você. É um imbecil! Não viu como sofria com as respostas da mesa? Não reparou na bengala dele? Sabe tocar violino, é verdade, mas até os idiotas podem fazê-lo. Todas as suas palavras revelam um estúpido...

Ada, após ouvir-me com aspecto de quem não se resolve a admitir no sentido próprio as palavras que the são dirigidas, interrompeu-me. Ergueu-se, sempre com o violino e o arco nas mãos, e voltou a dirigir-me palavras ofensivas. Fiz o que pude para esquecê-las e consegui. Recordo apenas que me

\footnotetext{
${ }^{90}$ Lo guardavo per sentire meglio quello ch'egli diceva. Era un bellissimo giovine: le labbra naturalmente socchiuse lasciavano vedere una bocca di denti bianchi e perfetti. L'occhio suo era vivace ed espressivo e, quando s'era scoperto il capo, avevo potuto vedere che i suoi capelli bruni e un po' ricciuti, coprivano tutto lo spazio che madre natura aveva loro destinato, mentre molta parte della mia testa era stata invasa dalla fronte. Ibid., p. 735.
} 
perguntou em voz alta como ousava falar assim dele e dela! Arregalei os olhos de surpresa, pois achava que falava exclusivamente dele. Esqueci as muitas palavras de desdém que ela me dirigiu, mas não a sua face, bela, nobre e sadia, enrubescida pelo desdém e cujas linhas com indignação se tornavam mais precisas, quase marmóreas. Jamais esquecerei; e quando penso em amor da juventude, revejo a bela, nobre e sadia face de Ada no momento em que me eliminou definitivamente de seu destino. ${ }^{91}$ (SVEVO, 2006, p.133, grifo nosso)

Zeno busca convencer Ada de que Guido não seria o melhor homem para ela, mas suas tentativas são inúteis e ele conclui, com amarga ironia que, naquele momento, Ada o eliminara definitivamente de seu destino, como esposa. De acordo com Teresa de Lauretis, a única arma de Zeno na luta contra seu rival é o ridículo, que lhe permite mostrar a própria superioridade mascarada pelo humorismo. (LAURETIS, 1976, p.31).

A postura de Ada fere, principalmente, o ego de Zeno, que parece não gostar de ser contrariado. Além do mais, atordoado com a reposta da amada, movido por impulso e, sobretudo, para mostrar a Ada que ela fora incapaz de reconhecer nele um bom partido, decide pedir em casamento Alberta, irmã mais nova de Ada, que também recusa o pedido. Sem Ihe restar escolha, ele então vai até Augusta, a irmã mais velha, que ele achara a mais feia de todas:

\footnotetext{
91 - Ada! Quell'uomo non fa per voi. È un imbecille! Non v'accorgeste come sofferse per i responsi del tavolino? Avete visto il suo bastone? Suona bene il violino, ma vi sono anche delle scimmie che sanno suonarlo. Ogni sua parola tradisce il bestione... / Essa, dopo d'esser stata ad ascoltarmi con l'aspetto di chi non sa risolversi ad ammetere nel loro senso le parole che gli sono dirette, m'interruppe. Balzò in piedi sempe col violino e l'arco in mano e mi soffiò addosso delle parole offensive. Io feci del mio meglio per dimenticarle e vi riuscii. Ricordo solo che cominciò col domandarmi ad alta voce come avevo potuto parlare così di lui e di lei! lo feci gli occhi grandi dalla sorpresa perché mi pareva di non aver parlato che di lui solo. Dimenticai le tante parole sdegnose ch'essa mi diresse, ma non la sua bella, nobile e sana faccia arrossata dallo sdegno e dalle linee rese più precise, quasi marmoree, dall'indignazione. Quella non dimenticai più e quando penso al mio amore e alla mia giovinezza, rivedo la faccia bella e nobile e sana di Ada nel momento in cui essa m'eliminò definitivamente dal suo destino. Ibid., pp. 759-760.
} 
(...) Cheguei diante dela [Augusta] e perguntei de chofre:

- Augusta, você gostaria que nos casássemos?

A proposta era sem dúvida rude. la casar com ela e ela comigo, e não lhe perguntava o que pensava disso, nem imaginava que pudesse ser levado a dar explicações.

Augusta ergueu os olhos arregalados de surpresa, fazendo com que o olho estrábico parecesse ainda mais diferente do outro. Sua face aveludada e branca, a princípio, empalideceu e logo depois congestionou-se. Agarrou-se com a mão direita o copo que tremia sobre a bandeja. Com um fio de voz disse-me:

- Você está brincando e isso não se faz. ${ }^{92}$ (SVEVO, 2006, p.136, grifo nosso)

Com o ego "sangrando" por ser contrariado, Zeno de modo bufo, em uma postura que vai do trágico ao cômico e vice-versa, decide esposar a irmã, que ele anteriormente descrevera da pior maneira possível. Sua postura é grosseira e egoísta e deixa a futura esposa incrédula sobre a veracidade do pedido de casamento, achando que seria mais uma das histórias inventadas por ele. Além de rude e egoísta a postura de Zeno com Augusta é cruel e muito machista:

- Não estou brincando - disse sério e triste. - Primeiro pedi a mão de Ada, que me recusou com ira; depois pedi a de Alberta, e ela recusou-me também, com belas palavras. Não guardo rancor nem de uma de outra. Apenas me sinto muito, muito infeliz.

Diante de minha dor, Augusta recompôs-se e olhou-me comovida, refletindo intimamente. Seu olhar semelhava uma carícia que não me causava prazer.

\footnotetext{
${ }^{92}$ (...) Mi misi a lei [Augusta] di faccia e subito le dissi: - Sentite, Augusta, volete che noi due ci sposiamo? / La proposta era veramente rude. lo dovevo sposare lei e lei me, ed io non domandavo quello ch'essa pensasse né pensavo potrebbe toccarmi di essere io costretto di dare delle spiegazioni. Se non facevo altro che quello che tutti volevano! / Essa alzò gli occhi dilatati dalla sorpresa. Così quello sbilenco era anche più differente del solito dall'altro. La sua faccia vellutata e bianca, dapprima impallidì di più, eppoi subito si congestionò. Afferrò con la destra il bicchiere che ballava sul vassoio. Con un filo di voce mi disse: - Voi scherzate e ciò è male. Ibid., p.763.
} 
- Devo então saber e recordar sempre que você não tem amor por mim? - perguntou. (...)

- É certo. Amo apenas Ada, mas me casarei com você... ${ }^{93}$ (SVEVO, 2006, pp.136-137, grifo nosso)

(...)

- Zeno, você precisa de uma mulher que queira viver a seu lado e tome conta de você. Hei-de ser essa mulher. ${ }^{94}$ (SVEVO, 2006, p.137)

O protagonista, além de afirmar com todas as letras que não ama Augusta, faz questão de ressaltar seu amor pela outra irmã. A passagem também é marcada por um tom burlesco, que ao lado da ironia agem como mecanismos que percorrem toda a narrativa, o que nos leva a questionar se de fato tal pedido ocorrera da forma descrita por Zeno. Além do mais, o protagonista escreve para um leitor específico, seu psicanalista, e desde o início deixa claro que sua história será marcada por verdades e mentiras, consequentemente, o tom frio e cortante do pedido de casamento pode ser mais uma de suas criações.

Sem saber lidar com tal rejeição, Zeno termina por recorrer à mulher certa, a mulher que ele sempre buscou, ou seja, a companheira e mãe que irá cuidar dele. A maturidade serena de Augusta propiciará a Zeno uma vida mais confortável e tranquila e, Ihe garantirá um lugar na família Malfenti. Desse

\footnotetext{
${ }^{93}$ - lo non scherzo, - dissi serio e triste. - Domandai dapprima la sua mano ad Ada che me la rifiutò con ira, poi domandai ad Alberta di sposarmi ed essa, con belle parole, vi si rifiutò anch'essa. Non serbo rancore né all'una né all'altra. Solo mi sento molto, ma molto infelice. / Dinanzi al mio dolore essa si ricompose e si mise a guardarmi commossa, riflettendo intensamente. II suo sguardo somigliava ad una certezza che non mi faceva piacere. / - lo devo dunque sapere e ricordare che voi non mi amate? - domandò. (...) / - Sì! lo non amo che Ada e sposerei ora voi... Ibid., pp. 763-764.

94 - Voi, Zeno, avete bisogno di una donna che voglia vivere per voi e vi assista. lo voglio essere quella donna. Ibid., p.765.
} 
modo, o protagonista, ainda que sem saber, tomara a decisão mais certa ao pedir Augusta em casamento.

Ada se casará com Guido, contudo Zeno jamais a esquecerá e, sempre verá em Guido o rival que Ihe roubara a mulher amada. O ódio e ressentimento pelo senhor Speier, que também se inserem nos sentimentos triangulares segundo Girard, darão tom à relação entre os cunhados. Guido, conforme o que nos conta Zeno, não nutre desafetos pelo cunhado, vendo-o como um amigo.

Caberá a Ada, após a morte do marido, dizer ao cunhado que ele sempre odiara Guido. Ada, magoada com a ausência do cunhado no funeral do marido, parece não Ihe perdoar e aproveita tal momento para dizer a Zeno o sentimento que ele sempre nutrira pelo cunhado:

- E eu o desculpo por não ter vindo ao enterro. Você não podia fazê-lo e eu perdoo. Ele também o desculparia se estivesse vivo. Que haveria você de fazer naquele enterro? Você, que não gostava dele! Bom como você é, poderia chorar por mim, pelas minhas lágrimas, mas não por ele que você... odiava! Pobre Zeno! Meu pobre irmão!

- Mas é um erro, uma mentira uma calúnia. Como você pode acreditar numa coisa destas? ${ }^{95}$ (SVEVO, 2006, p.383, grifo nosso)

Zeno tenta se defender das acusações de Ada, sem êxito. Ainda que o protagonista negue as afirmações da cunhada, sabemos que o sentimento que

${ }^{95}$ - Ed io ti scuso per non esser venuto al suo funerale. Tu non potevi farlo ed io ti scuso. Anche lui ti scuserebbe se fosse ancora vivo. Che ci avresti fatto tu al suo funerale? Tu che non lo amavi! Buono come sei, avresti potuto piangere per me, per le mie lacrime, ma non per lui che tu... odiavi! Povero Zeno! Fratello mio! (...) / - Ma è un errore, una menzogna, una calunnia. Come fai a credere una cosa simile? Ibid., p. 1042. 
Zeno tinha pelo cunhado não era afetuoso ou fraternal. Guido nunca deixou de ser um rival odiado por Zeno. A morte, neste contexto, representa o término da rivalidade entre os cunhados, a desconfiguração do triângulo amoroso e, de certa forma uma vitória de Zeno que, preterido por Ada se tornara o símbolo do homem bem sucedido e bom marido.

As relações amorosas triangulares não se restringem à tríade Zeno/Ada/Guido. As memórias de Zeno são marcadas por triângulos amorosos, adultério, ciúmes movidos por rivais reais ou imaginários. Zeno, que se casara com Augusta por motivos já discorridos, não deveria sentir ciúmes da esposa, que a seus olhos não é bela, todavia demonstra sentir tal sentimento, despertado por um rival imaginário:

Minha mulher despediu-se de mim juntamente com o doutor. Disse-me sorrindo:

- Já que você assim resolveu, aguente firme.

Seu sorriso, que eu amava tanto, pareceu-me zombeteiro e foi exatamente nesse instante que germinou em meu espírito um sentimento novo que levaria uma tentativa iniciada com tanta seriedade a falir miseravelmente. Senti-me logo mal e percebi o que me fazia sofrer quando me deixara só. Um estúpido e amargo ciúme pelo jovem doutor. Ele era bonito, livre! Por que minha mulher não haveria gostar dele? ${ }^{96}$ (SVEVO, 2006, pp.29-30, grifo nosso)

Zeno decide internar-se em uma clínica para curar-se de sua grande doença, o vício do fumo. A mulher o acompanha na internação, contudo ao vê-

\footnotetext{
${ }^{96}$ Mia moglie si congedò da me insieme al dottore. Mi disse sorridendo: - Giacchè hai deciso così, sii forte. / II suo sorriso che io amavo tanto mi parve una derisione e fu proprio in quell'istante che nel mio animo germinò un sentimento nuovo che doveva far sì che un tentativo intrapeso con tanta serietà dovesse subito miseramente fallire. Mi sentii subito male, ma seppi che cosa mi facesse soffrire soltanto quando fui lasciato solo. Una folle, amara gelosia per il giovane dottore. Lui bello, lui libero! Perché mia moglie non l'avrebbe amato? Ibid., p. 644.
} 
la sair na companhia do médico, Zeno é traído por sua imaginação, por sua insegurança e seu ciúme. O médico, rival imaginário, uma vez que Augusta, segundo a narrativa, é uma mulher séria e correta, que jamais trairia o marido, no entanto "tratava-se de um belo jovem...os seus vívidos olhos negros, era a imagem da elegância, na indumentária toda branca do colete aos sapatos"97 (SVEVO, 2006, p.27). A configuração do triângulo seria, então:

\section{Dr. MULI}

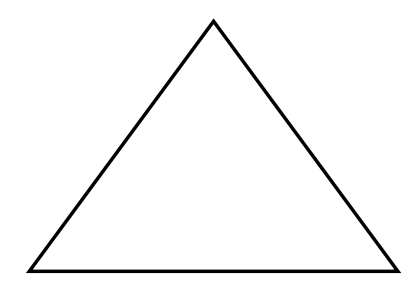

ZENO

AUGUSTA

Assim como os outros rivais, o médico nos é descrito pelo protagonista com uma beleza física superior à dele. $\mathrm{Na}$ relação sujeito-desejante e rival/mediador é constante essa dualidade: inferior $\mathrm{x}$ superior; o sujeitodesejante sempre se sentirá inferior a seu rival. Tal fato liga-se ao caráter inapto do protagonista, que se sente em desvantagem com os outros homens e, consequentemente, é alvo do ciúme:

(...) Já não fumava havia meia hora e nem pensava verdadeiramente nisso, ocupado que andava em imaginar minha mulher em companhia de Muli. ${ }^{98}$ (SVEVO, 2006, p.31)

\footnotetext{
97 ...era un bel giovane... i suoi vivaci occhi neri, era l'immagine dell'elleganza, nel suo vestito bianco dal colletto fino alle scarpe. Ibid., pp. 641-642.

98 (...) Ora non fumavo già da mezz'ora e non ci pensavo affato, occupato com'ero dal pensiero di mia moglie e del dottor Muli. Ibid., p.646.
} 
(...) Súbito ocorreu-me que, enquanto me torturava com o pensamento de que minha mulher estaria aproveitando minha reclusão para trair-me, talvez o médico ainda se achasse ali na casa de saúde, o que me faria recuperar a tranquilidade. ${ }^{99}$ (SVEVO, 2006, p.33, grifo nosso)

O protagonista tortura-se com a ideia da traição de sua esposa com o médico, Dr. Muli. Sua imaginação constrói uma cena que não condiz com a realidade. A propósito da imaginação, Nicolas Grimald, em O ciúme: estudo sobre o imaginário proustiano, analisa minuciosamente a presença do ciúme na obra de Proust, levando em consideração a imaginação do sujeito, "vítima" desse sentimento. De acordo com ele, "o ciúme seria assim tanto mais torturante quanto mais entregue ao imaginário, e a imaginação tanto mais intensa e dolorosa quanto mais visualizasse a mulher amada numa infinidade de encontros, situações, gestos e comportamentos possíveis" (GRIMALDI, 1994, p.46).

Zeno, de fato, através de sua fértil imaginação visualiza a mulher nos braços do médico, isso o apavora e ele decide subornar a enfermeira e foge da clínica no intuito de surpreender a esposa e o Doutor Muli, todavia ao retornar à casa e vasculhar todos cômodos, tem certeza de que nada acontecera entre sua esposa e o médico.

O ciúme que Zeno demonstra pela esposa leva-nos a questionar a descrição depreciativa feita por ele quando conhecera Augusta:

99 (...) Intravvidi la possibilità che intanto ch'io mi cruciavo al pensiero che mia moglie approfittasse dela mia reclusione per tradirmi, forse il dottore si trovasse tuttavia nella casa di salute, nel quale caso io avrei potuto riavere la mia tranquilità. Ibid., p.648. 
Eis que das quatro jovens com a mesma inicial uma para mim já não contava. Como tiveram coragem de achá-la bonita [Augusta]? A primeira coisa que se notava nela era 0 estrabismo tão pronunciado que, evocando-a mais tarde, conseguia personificá-la toda. Os cabelos, não muito abundantes, eram louros, de um tom esmaecido, isento de luz, e o corpo, embora interessante, era um pouco gordo demais para a idade. Nos poucos instantes que estive só, pensei: "Se as outras são parecidas com esta!..."100 (SVEVO, 2006, p.76)

Recordei que, ao ver Augusta pela primeira vez, fui surpreendido pela feiura, visto que estava na expectativa de que as quatro moças de inicial " $A$ " daquela casa fossem todas belíssimas. ${ }^{101}$ (SVEVO, 2006, p.164)

Se Augusta fosse tão feia e pouco interessante, como descrita por Zeno, ela não seria objeto de desejo de nenhum homem, consequentemente o ciúme do protagonista não teria razão para existir. Todavia, Zeno demonstra sentir ciúme da esposa, o que nos leva a duvidar da veracidade da caracterização depreciativa feita inicialmente. Diríamos que Zeno precisava sentir-se superior a alguém, uma vez que diz ser tão fraco e incapaz. Esse sentimento de superioridade é buscado pelo protagonista por intermédio da "cruel" inferiorização da mulher. O senhor Cosini procura diminuir a esposa talvez impulsionado por certa inveja, uma vez que ela, em seu pequeno mundinho, demonstra ser uma mulher realizada, feliz e sã. Ele, ao contrário, sente-se frustrado, infeliz e doente. Daí a necessidade de aniquilar aqueles que se

\footnotetext{
${ }^{100}$ Ecco che delle quattro fanciulle dalla stessa iniziale una ne moriva in quanto mi riguardava. Come avevano fatto a dirla bella [Augusta]? La prima cosa che in lei si osservava era lo strabismo tanto forte che, ripensando a lei dopo di non averla vista per qualche tempo, la personificava tutta. Aveva poi dei capelli non molto abbondanti, biondi, ma di un colore fosco privo di luce e la figura intera non disgraziata, pure un po' grossa per quell'età. Nei pochi istanti in cui restai solo pensai: "Se le altre tre somigliano a questa!...". Ibid., p. 695.

${ }^{101} \mathrm{Mi}$ ricordai che al vedere Augusta ero stato distratto dalla sua bruttezza visto che m'ero atteso di trovare in quella casa le quattro fanciulle dalliniziale in a tutte bellissime. Ibid., pp. 793-794.
} 
encontram à sua volta, em especial, a própria esposa, a única que conseguirá proporcionar um pouco de felicidade e saúde à sua existência. Augusta representa, ainda, um importante ponto de apoio para um espírito destinado à inquietação e à solidão interior (CLAAR, 1986, p.26,).

À medida que nos conta sua história, Zeno parece descobrir certa beleza na esposa, que é vista sob um olhar diferente. Esta "era muito menos feia do que eu imaginava, e descobri sua maior beleza quando a beijava: o rubor!" 102 (SVEVO, 2006, p.149). Confuso, ele se questionará, inúmeras vezes, se, de fato, não sente amor por Augusta: "- Será que a amo? Trata-se de uma dúvida que me acompanhou por toda a vida, até hoje posso pensar que o amor eivado de tanta dúvida é o verdadeiro amor"103 (SVEVO, 2006, p.142). O protagonista, em determinados momentos, chega a declarar que ama a esposa, contudo, logo em seguida, esse "amor" é colocado na berlinda, visto como algo efêmero:

Em minha vida houve vários períodos em que me acreditei no caminho da saúde e da felicidade. Contudo, tal crença nunca foi tão forte quanto por ocasião da viagem de núpcias e das semanas que se seguiram ao nosso retorno. Começou com uma descoberta que me surpreendeu: eu amava Augusta como ela a mim. Desconfiado a princípio, desfrutava a felicidade de um dia, sempre na suposição de que tudo mudaria no seguinte. Contudo, uns se seguiam aos outros, semelhantes todos, luminosos, em que perdurava a amabilidade de Augusta e eis a surpresa - a minha! A cada manhã encontrava nela o mesmo afeto comovido e em mim o mesmo reconhecimento que, se não era amor, se lhe assemelhava muito. Quem haveria de prevê-lo, quando andei saltitando de Ada para Alberta e desta para Augusta? Descobri que não fora um

\footnotetext{
102 ... era molto meno brutta di quanto avessi creduto, e la sua più grande bellezza la scopersi baciandola: il suo rossore! Ibid., p. 778.

${ }^{103}$ - Chissà se l'amo? È un dubbio che m'accompagnò per tutta la vita e oggidì posso pensare che l'amore accompagnato da tanto dubbio sia il vero amore. Ibid., p. 770.
} 
paspalho cego, guiado pelos outros, mas pessoa habilíssima. ${ }^{104}$ (SVEVO, 2006, p.157, grifo nosso)

As dúvidas e a postura hesitante de Zeno confirmam o seu caráter inapto; a capacidade de reflexão é mais desenvolvida do que a de ação. Diferentemente de Alfonso Nitti e Emilio Brentani, Zeno Cosini mostra-se mais habilidoso e sagaz ao tirar proveito de situações que pareciam totalmente fadadas ao fracasso, ainda que seja "favorecido pela sorte" como bem notou o crítico Debenedetti (DEBENEDETTI, 1995, p.80). A esse propósito, a escolha da esposa certa, bem como a riqueza que ele acumula ao agir por conta própria, em meio à guerra, são bons exemplos de um "inapto bem sucedido", que por sua vez, apontam para o amadurecimento do protagonista se comparados com Alfonso Nitti e Emilio Brentani.

Seu casamento alicerça-se em conveniências, para ambas as partes. $O$ elemento ficcional e fantasioso não faz parte de sua relação com Augusta e por isso, constitui-se em um matrimônio harmonioso e mais pleno para os dois cônjuges.

Zeno sabe vestir, perfeitamente, a "máscara" de esposo fiel e zeloso que retribui o carinho recebido da esposa, com agrados e mimos materiais.

\footnotetext{
${ }^{104}$ Nella mia vita ci furono varii periodi in cui credetti di essere avviato alla salute e alla felicità. Mai però tale fede fu tanto forte come nel tempo in cui durò il mio viaggio di nozze eppoi qualche settimana dopo il nostro ritorno a casa. Cominciò con una scoperta che mi stupi: io amavo Augusta com'essa amava me. Dapprima diffidente, godevo intanto di una giornata e m'aspettavo che la seguente fosse tutt'altra cosa. Ma una seguiva e somigliava all'altra, luminosa, tutta gentilezza di Augusta ed anche - ciò ch'era la sorpresa - mia. Ogni mattina ritrovavo in lei lo stesso commosso affetto e in me la stessa riconoscenza che, se non era amore, vi somigliava molto. Chi avrebbe potuto prevederlo quando avevo zoppicato da Ada ad Alberta per arrivare ad Augusta? Scoprivo di essere stato non un bestione cieco diretto da altri, ma un uomo abilissimo. Ibid., p. 786.
} 
Todavia, como ele próprio afirma viver "numa simulação de atividade"105 (SVEVO, 2006, p.170), o tédio o conduziu ao adultério com uma bela jovem, chamada Carla. Para justificar a traição, Zeno diz em várias passagens ter sido induzido a cometer o adultério:

Ela decidiu imediatamente; agarrou-me a mão para forçar-me a entrar. A emoção obscureceu-me a vista e admito que tenha sido provocada não pelo doce contato da mão, mas por aquela familiaridade que me pareceu decisiva do meu destino e do de Augusta. Ainda assim, creio ter entrado com certa relutância e, quando reevoco a história de minha primeira traição, tenho o sentimento de que só procedi desse modo porque a isso fui induzido. ${ }^{106}$ (SVEVO, 2006, p.185, grifo nosso)

A infidelidade de Zeno, estimulada pelo ócio e inatividade, tem início a partir de sua relação com o amigo Copler, um sujeito acometido de nefrite, enfim, um doente real. $O$ pobre Copler, totalmente resignado à sua enfermidade real, deixa de exercer qualquer atividade profissional e passa a se dedicar à filantropia. Por intermédio da filantropia, praticada pelo amigo, Zeno conhece Carla Gerco e decide "investir" na carreira artística da bela jovem. Assim, inicia-se o adultério de Zeno e a constituição de mais uma relação triangular no romance. Augusta não saberá do caso extraconjugal do marido, contudo Carla sabe que Zeno é casado, consequentemente, será a senhorita Gerco a ver em Augusta sua rival:

\footnotetext{
${ }^{105}$ In una simulazione di attività. Ibid., p. 800.

${ }^{106}$ Essa subito decise, perché afferrò la mia mano per trattenermi più sicuramente e mi fece entrare. L'emozione m'oscurò la vista e ritengo sia stata provocata non tanto dal dolce contatto di quella mano, ma da quella familiarità che mi parve decidesse del mio e del destino di Augusta. Perciò credo di essere entrato con qualche riluttanza e, quando rievoco la storia del mio primo tradimento, ho il sentimento di averlo compiuto perché trascinatovi. Ibid., p. 818.
} 


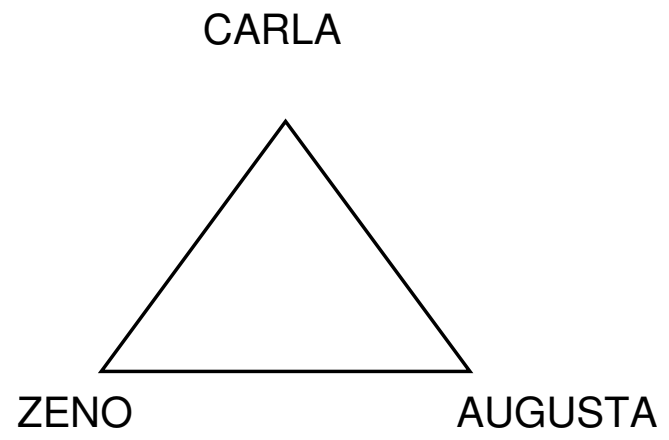

Assim como as outras mulheres, que são objetos de desejo dos protagonistas, a senhorita Carla possui uma beleza marcante, que seduz Zeno e desperta seus desejos:

(...) E era de fato graciosa! Creio que se esforçava por parecer mais jovem do que era, com a saia curta demais para a moda da época, a menos que a usasse em casa uma roupa dos tempos em que ainda não havia terminado de crescer. Sua cabeça, no entanto, era de uma mulher feita e, a julgar pelo penteado bastante rebuscado, de mulher que quer agradar. As grossas tranças escuras estavam dispostas de modo a cobrir as orelhas e em parte também o pescoço. (...) Sua voz tinha uma suavidade especial quando falava e, com uma afetação que acabou por se tornar natural, comprazia-se em estender as sílabas como se quisesse acariciar os sons que conseguia produzir. (...) Nela tudo soava como palavra de amor. ${ }^{107}$ (SVEVO, 2006, pp.177-178, grifo nosso)

Além da beleza física de Carla, chama-nos atenção as vestes da moça, cuja descrição de Zeno leva o leitor ao riso, ao dizer que talvez ela usasse uma roupa dos tempos de menina. Além do humor podemos dizer que a caracterização física da moça, remete-nos à descrição de Angiolina. Carla,

${ }^{107}($...) Ed era veramente graziosa! Credo che essa volesse sembrare più giovine di quanto non fosse, con la sua gonna troppo corta per la moda di quell'epoca a meno che non usasse per casa una gonna del tempo in cui non aveva ancora finito di crescere. La sua testa era però di donna e, per la pettinatura alquanto ricercata, di donna che vuol piacere. Le ricche treccie brune erano disposte in modo da coprire le orecchie e anche in parte il collo. (...) La sua voce aveva qualche cosa di musicale quando parlava e, con un'affettazione oramai divenuta natura, essa si compiaceva di stendere le sillabe come se avesse voluto carezzare il suono che le riusciva di metterci. (...) Ogni suo suono mi pareva d'amore. Ibid., p. 809. 
assim como a senhorita Zarri, constituem-se em duas coquetes, que buscam despertar a admiração e o desejo do sexo oposto através dos atributos físicos. De acordo com Girard, a coquete além de querer passar por uma mulher virtuosa, também quer desfrutar das vantagens que o coquetismo lhe oferece, assim, na maioria das vezes, ela termina por escolher uma zona de penumbra entre o vício e a virtude (GIRARD, 2012, p.105).

Se a descrição física da moça é destacada, as observações do protagonista, quanto a seu suposto talento são desalentadoras e, indiretamente, ele afirma que a única vocação da moça, a que lhe cabe nesta sociedade burguesa, é a de ser "a amante", "a outra", aquela que vive um "amor" clandestino, às ocultas, tirando deste algum proveito.

De acordo com Lauretis, o caso extraconjugal de Zeno não só remete à aventura entre Emilio e Angiolina, mas também é apresentado como uma prova alcançada da virilidade do herói que está no controle da situação e joga com Carla, assim como ela joga com ele; ou seja, como Angiolina jogara com Emilio. Desse modo Carla seria o que o senhor Brentani queria com a senhorita Zarri, uma aventura fácil e breve (LAURETIS, 1976, p.48).

O desejo de Zeno por Carla "aumentava constantemente", conforme ele próprio afirma (SVEVO, 2006, p.181). A amante ao lado da esposa, Augusta, são importantes para Zeno e para seu casamento, uma vez que ambas atuam como "figuras complementares que juntas constituem a mulher ideal de Zeno (mãe + amante)"108 (LAURETIS, 1976, p.60, tradução nossa). Importante

\footnotetext{
${ }^{108}$ figure complementari che insieme costituiscono la donna ideale di Zeno (madre + amante). In LAURETIS, Teresa de. La sintassi del desiderio: Struttura e forme del romanzo sveviano. Ravenna : Longo Editore, 1976, p.60.
} 
ressaltar que neste momento a abordagem psicanálica é cabível e faz-se necessária.

Nem mesmo o sentimento de culpa, confessado por ele em certos momentos, bastará para colocar um fim em suas aventuras amorosas extraconjugais. Por vezes, Zeno tentará terminar a relação com Carla, mas isso não acontecerá. Assim como a ciranda do último cigarro, ele viverá o eterno propósito da "última traição". A comparação do adultério ao último cigarro, bem como a sensação de culpa, são explicitados por ele mesmo:

Posteriormente, quando de fato me tornei amante de Carla, voltando a pensar naquela triste tarde, não cheguei a compreender por que antes de comprometer-me mais a fundo não fui detido por algum propósito mais firme. Tinha lamentado tanto minha traição antes de cometê-la que talvez parecesse ter sido fácil evitá-la. Podemos rir das boas intenções que ocorrem depois do acontecido, como também das que o antecedem, pois não valem de nada. Nas horas angustiosas de então, marquei em grossos caracteres no meu livro de endereços, na letra C (Carla), aquela data com a seguinte nota: "última traição". Mas a primeira traição efetiva, que conduziu a traições ulteriores, só teve lugar no dia seguinte. ${ }^{109}$ (SVEVO, 2006, p.204, grifo nosso)

Assim como o bom propósito de parar de fumar o, também, bom propósito de pôr fim ao adultério nunca chegará, ao menos da parte de Zeno. Sabemos que a "última traição" só se concretizará porque a amante decide

\footnotetext{
${ }^{109}$ Più tardi, quando fui effettivamente l'amante di Carla, riandando col pensiero a quel triste pomeriggio non arrivai a intendere perché prima d'impegnarmi più oltre, non $\mathrm{mi}$ fossi arrestato con un virile proposito. Avevo tanto pianto il mio tradimento prima di commetterlo, che si sarebbe dovuto credere facile di evitarlo. Ma del senno di poi si può sempre ridere e anche di quello di prima, perché non serve. Fu marcata in quelle ore angosciose in caratteri grandi nel mio vocabolario alla lettera C (Carla) la data di quel giorno con l'annotazione: "ultimo tradimento". Ma il primo tradimento effettivo, che impegnava a tradimenti ulteriori, seguì soltanto il giorno dopo. In SVEVO, Italo. Romanzi e "continuazioni". Milano: Mondadori, 2006, p. 840.
} 
casar-se com seu professor de canto, pago pelo próprio Zeno. Assim, o rival "rouba-Ihe" a amante.

Zeno soube aproveitar muito bem todos os deleites que essa aventura poderia lhe proporcionar, no entanto, o ciúme também assombrou os dois amantes:

Depressa os meus dias passaram a sofrer complicações. De manhã, trazia para a casa de Carla, além do amor, um amargo ciúme, que se tornava muito menos amargo ao longo do dia. Parecia-me impossível que aquele rapaz não se aproveitasse da fácil e apetitosa presa. Carla mostrava-se surpresa por eu pensar uma coisa destas, mas sua surpresa me fez pensar ainda mais. (...)

Um dia, cheguei à sua casa furioso de ciúme e ela, espavorida, propôs-me imediatamente despedir o maestro. ${ }^{110}$ (SVEVO, 2006, p.241, grifo nosso)

Ainda que a relação entre o protagonista e Carla não passe de uma aventura sexual, Zeno demonstra sentir ciúme da moça, um ciúme que se liga diretamente com o desejo de posse e de exclusividade do macho sobre a fêmea. A postura de Zeno evidencia as relações entre os sexos na sociedade representada, nela a mulher é vista como um objeto a ser caçado e, mesmo na condição de amante, deve ser fiel e subalterna ao homem.

Diferentemente de Alfonso e Emilio que eram dominados e paralisados por seus ciúmes, sem conseguirem chegar à entrega e a uma satisfação mais plena de seus desejos, Zeno lança-se mais às situações que o envolvem e

\footnotetext{
${ }^{110}$ Ben presto la mia giornata subì delle complicazioni. Alla mattina portavo da Carla oltre che amore anche un'amara gelosia, che diveniva molto meno amara nel corso della giornata. Mi pareva impossibile che quel giovionotto non approfittasse della buona, facile preda. Carla pareva stupita ch'io potessi pensare una cosa simile, ma io lo ero altrettanto al vederla stupita. (...) / Un giorno arrivai a lei furibondo di gelosia ed essa spaventata si dichiarò subito pronta di congedare il maestro. Ibid., pp. 881-882.
} 
mesmo sendo acometido por seu ciúme chega a um gozo maior da vida e de seus deleites.

O ciúme, a rivalidade, a inveja, enfim, todos os sentimentos classificados como triangulares por Girard, povoam a consciência de Alfonso, Emilio e Zeno que não conseguem viver relações que não sejam triangulares, e sempre estão à mercê da presença de um terceiro, um rival ou mediador, sempre superior a eles. Desse modo, pode-se dizer que o ciúme é intrínseco à personalidade desses personagens inaptos, no entanto discorrermos sobre essa faceta de suas personalidades na sequência. 


\section{Personagem inetto em cena na obra sveviana:}

\section{breve apresentação}

A presença do chamado personagem inetto (literalmente o inapto) é recorrente não só nos três romances, mas também em outros textos do escritor triestino Italo Svevo, constituindo-se em um dos grandes motes de sua narrativa. O tema da "inettitudine" em sua obra suscita inúmeras discussões, pois Svevo coloca em cena um homem praticamente destituído das qualidades essenciais para ter sucesso no universo representado, de modo que se apresenta como um fraco diante dos obstáculos cotidianos, incapaz de adaptar-se à vida em sociedade.

Victor Brombert, no texto Em louvor de anti-heróis: figuras e temas da moderna literatura europeia, estuda a figura do "anti-herói" na literatura, especialmente dos séculos XIX e XX. Para o crítico, as fronteiras que separam o que é heroico do não-heroico encontram-se em suspenso, seus limites foram “derrubados" (BROMBERT, 2001, p.14). A caracterização do anti-herói, feita pelo crítico, é mesma do personagem inapto, descrito na narrativa sveviana:

A literatura dos séculos XIX e XX está, além disso, abarrotada de personagens fracos, incompetentes, dessorados, humilhados, inseguros, ineptos, às vezes abjetos - quase sempre atacados de envergonhada e paralisante ironia, mas às vezes capazes de inesperada resistência e firmeza. Esses personagens não se ajustam aos modelos tradicionais de figuras heroicas; até se contrapõem a eles. Mas pode haver grande vigor nessa oposição. Implícita ou explicitamente lançam dúvidas sobre valores que vêm sendo aceitos ou que foram julgados inabaláveis. (BROMBERT, 2001, p.14, grifo nosso) 
Os protagonistas dos romances, Una Vita, Senilità e La coscienza di Zeno, que fazem parte de nosso corpus de análise, possuem várias das características apontadas por Brombert. Se por um lado, mostram-se fracos, inaptos, incompetentes, inseguros, levianos e mentirosos, por outro vivenciam determinadas situações em que apresentam discursos bem articulados, e, na maioria das vezes, demonstram ser conscientes de suas fraquezas e limitações.

Brombert define um personagem recorrente na narrativa sveviana, ou seja, a do sujeito fragmentado, testemunho da indecisão do próprio agir; o inapto que pode ser interpretado ainda como o "doente", por não conseguir integrar-se à vida em sociedade. A doença, outro ponto nevrálgico da obra sveviana, a qual não trataremos aqui, consiste, grosso modo, na incapacidade desse sujeito em incorporar os valores da sociedade burguesa, da qual ele faz parte, e por não conseguir enxergar-se como integrante da mesma. De acordo com Nicoletta Donati:

O drama constante no qual o personagem sveviano debate-se é aquele do indivíduo inapto a viver, condenado à impotência no desumanizado mundo burguês. De um lado há o mundo burguês com suas falsas certezas e seus rituais obtusos, do outro há as testemunhas da dúvida e da crise, os apóstolos de uma ideia qualquer ou do nada, para dizê-lo com Svevo, os exilados da vida burguesa, "porque buscam a vida dos homens". Para um escritor como Svevo, a consciência da exclusão encontra-se no contraste entre o mundo familiar burguês, das exigências superficiais do espírito e o seu mundo interior, feito de ideias, mas também de alienação intelectual. ${ }^{111}$ (DONATI, 2000, p.15, tradução nossa)

\footnotetext{
${ }^{111}$ II dramma costante in cui si dibatte il personaggio sveviano è quello dell'individuo inetto a vivere, condannato all'impotenza nel disumanizzante mondo borghese. Da una parte c'è il mondo borghese con le sue false certezze e i suoi ottusi rituali, dall'altra ci sono i testimoni del dubbio e della crisi, gli apostoli di qualche idea o del nulla, per dirla con Svevo, gli esiliati dalla vita dei borghesi "perché cercano la vita degli uomini". Per uno scrittore come Svevo la
} 
Segundo Camerino, a inettidutine seria o reflexo da inércia, do estado de renúncia e distanciamento da luta, sendo essa renúncia à luta que determina a inettitudine em Svevo, nunca o contrário. (CAMERINO, 1974, p.89)

Giuliano Manacorda afirma que a definição desse personagem foi o mote principal para a crítica sveviana, que buscou, sobretudo, caracterizar e individualizar a obra romanesca do escritor triestino, principalmente, através da figura do inapto (MANACORDA, 1972, p.165). Para Manacorda o protagonista de Svevo constitui-se em um complicado, débil, abúlico, inconsequente e incoerente, uma vez que o leitor não pode prever o que acontecerá na próxima página. Como ressalta o crítico, não se sabe, por exemplo, se Alfonso, protagonista do primeiro romance, na sequência da narrativa ganhará um beijo ou uma reprovação de Annetta (MANACORDA, 1972, p.166).

coscienza dell'esclusione è nel contrasto tra il mondo familiare borghese, dalle superficiali esigenze dello spirito e il suo mondo interiore, fatto di idee ma anche di alienazione intellettuale. In DONATI, Nicoletta. Svevo: crisi del soggetto ed estetica della crisi. Perugia, 1999/2000. Laurea in Filosofia. Università degli Studi di Perugia - Facoltà di Lettere e Filosofia, p.15. 


\subsection{Un inetto ou a representação de um sujeito comum?}

Como já dissemos no início do trabalho, o romance de estreia de Italo Svevo foi intitulado originalmente "Un inetto", pelo escritor triestino, mas teve seu título recusado pelo editor Treves. Sendo publicado, a seguir, com o título conhecido hoje.

Giampaolo Borghello observa que o "inetto" Alfonso é um indivíduo que, em termos etimológicos, é o não adaptado, é o não capaz (BORGHELLO, 1977, p.58). Nitti realmente apresenta várias características desse sujeito inapto, contudo uma análise mais atenta permite-nos, em certa medida, discordar, em determinados pontos, da crítica que vê nesse primeiro protagonista a personificação do completo inapto. Alfonso, a nosso ver, não é totalmente inábil, e isso fica comprovado durante a narrativa ${ }^{112}$. Esse comportamento oscilante do protagonista remete-nos à definição dada por Brombert, citada anteriormente, sobre os personagens, ou melhor, o anti-herói presente na literatura dos séculos XIX e XX.

Se o jovem Nitti fosse totalmente inapto não conseguiria, em tão pouco tempo e com pouca experiência de vida (referimo-nos ao fato do protagonista ter apenas 22 anos e ter morado a maior parte de sua vida no campo, conservando, acredita-se, certa ingenuidade), ser promovido no banco em que trabalhava, muito menos seduziria a filha de seu patrão e posteriormente abdicaria a uma ascensão social proveniente da união com a senhorita Annetta

\footnotetext{
${ }^{112}$ Mario Fusco ressalta que Svevo não se limita a fazer um retrato negativo do protagonista, pelo contrário coloca em cena um leque de reações que fazem contrapeso com a fraqueza e inércia de Nitti. In FUSCO, Mario. Italo Svevo: coscienza e realtà. Palermo: Sellerio Editore, 1984, pp.18-19.
} 
Maller. Por isso, afirmar que Alfonso é totalmente inapto e o que temos em cena é a história de um homem derrotado e fracassado, seria precipitado.

Consequentemente, acreditamos que o primeiro título "Un inetto" destoaria da história vivida por Nitti. Reconhecemos que esse protagonista apresenta características do inapto, e talvez o suicídio seja não o maior indício dessa sua incapacidade de viver em uma sociedade que lhe é hostil, como já se discutiu no primeiro capítulo, mas principalmente a negação de não querer pertencer à mesma. Aqui tocamos em um ponto fulcral que permeia os outros romances. O que seria a senilidade de Emilio Brentani, protagonista do segundo romance, Senilità, senão a negação de fazer parte dessa mesma sociedade, "recusada" drasticamente por Alfonso, através de seu suicídio? No terceiro romance, La coscienza di Zeno, tal negação aparece de forma mais irônica, quando o protagonista Zeno, um "doente" para aquela sociedade, propõe uma explosão mundial que permita começar tudo do zero, uma vez que é a sociedade que está corrompida e "doente" até as raízes.

A derradeira ação de Alfonso traz em seu germe certa ambiguidade; de um lado demonstra um ato de libertação (conforme palavras do próprio protagonista que mostraremos na sequência), por outro ressalta e coroa tal personagem com um dos maiores "inaptos" protagonistas svevianos, que não consegue agir e reagir diante dos desafios da vida. Todavia, há uma progressão, ou melhor, uma oscilação dessa inaptidão de Alfonso no romance, sendo essa variação que nos permite questionar a classificação de Alfonso como o "maior" inapto sveviano. 
Inicialmente, o protagonista é apresentado como frágil, como se fosse um menino assustado que se perdera da mãe, em meio à multidão da cidade grande, que ele deverá enfrentar inevitavelmente sozinho. A carta que abre o romance mostra-nos esse garoto indeciso, com medo, e que não quer romper os laços e a dependência com a mãe:

\begin{abstract}
"A senhora não acha, mamãe, que seria melhor eu voltar? Até o presente momento não vejo utilidade nenhuma em permanecer aqui. Dinheiro não posso the enviar, porque não tenho. Deram-me cem francos no primeiro mês, que à senhora pareceram grande coisa, mas aqui não valem nada. Eu me arrumo como posso, mas o dinheiro mal dá, quando dá.

"Começo a acreditar que seja muito, mas muito difícil ter sucesso nos negócios, como disse o tabelião Mascotti, a propósito dos estudos. É muito difícil. Meu salário é cobiçado e devo convir que não faço por merecê-lo. (...)
\end{abstract}

"Não seria melhor se eu voltasse para casa? Poderia ajudala em seu trabalho, poderia até mesmo trabalhar no campo, mas pelo menos leria em paz meus poetas, à sombra dos carvalhos, respirando aquele nosso ar puro, não contaminado.

"Mas quero contar-Ihe tudo: a arrogância de meus colegas ou de meus chefes não ajuda a diminuir meus aborrecimentos. Olham-me de cima para baixo porque se vestem melhor do que eu. São uns almofadinhas que passam metade do dia na frente do espelho. Uns boçais! (...)

"São essas as minhas preocupações e com uma única palavra a senhora pode acabar com elas. Diga-a e, em poucas horas, estarei ao seu lado. ${ }^{113}$ (SVEVO, 1993, p.14, grifo nosso)

\footnotetext{
113 "Non ti pare, mamma, che sarebbe meglio che io ritorni? Finora non vedo che ci sia grande utile per me a rimanere qui. Denari non ti posso inviare, perché non ne ho. Mi hanno dato cento Franchi al primo del mese, e a te sembra una forte somma, $\mathrm{m}$ aqui è nulla. lo m'ingegno come posso ma i denari non bastano, o appena appena. / "Comincio anche a credere che in commercio sia molto ma molto difficile di fare fortuna, altrettanto, quando a quello che ne disse il notaro Mascotti, negli studî. È molto difficile! La mia paga è invidiada e io debbo riconoscere di non meritarla. (...) / "Non farei meglio di ritornare a casa? Ti aiuterei nei tuoi lavori, lavorerei magari anche il campo, ma poi leggerei tranquillo i miei poeti, all'ombra delle quercie, respirando quella nostra buona aria incorrota. I "Voglio dirti tutto! Non poco aumenta i miei dolori la superbia dei miei colleghi e dei miei capi. Forse mi trattano dall'alto in basso perché vado vestito peggio di loro. Son tuttu zerbinotti che passano metà della giornata allo specchio. Gente sciocca! (...) / "Questi i miei affanni, e con una sola parola tu puoi annullarli. Dilla e in poche ore sono da te. In SVEVO, Italo. Romanzi e "continuazioni". Milano: Mondadori, 2006, pp.6-7.
} 
De acordo com Mario Fusco, tal carta é importante por introduzir o leitor "in media res" e por colocá-lo em contato com a história vivida pelo protagonista. Fusco ressalta dois pontos essenciais da missiva: a confissão de Alfonso à mãe sobre o mal-estar de viver na cidade, e a insistência do protagonista em implorar à matriarca a deixá-lo voltar a viver no campo, fugindo assim da vida no centro urbano e consequentemente dessa sociedade burguesa com a qual ele não consegue identificar-se (FUSCO, 1984, p.11). O protagonista parece não querer enfrentar a selva competitiva e desonesta na cidade. Nitti não parece estar pronto para assumir responsabilidades, amadurecer e chega a dizer que se sentia melhor quando era estudante, ou seja, quando era privado de compromissos, de obrigações. Neste primeiro momento encontramos um protagonista totalmente amedrontado para assumir não apenas a si próprio, mas principalmente as consequências que tal postura implicaria para sua vida.

Alfonso parece acreditar pouco em si mesmo, demonstrando um grande senso de inferioridade, que o acompanhará até a morte (FUSCO, 1984, p.12). No entanto, após a carta introdutória, com o decorrer da narrativa encontramos um Alfonso mais forte, mais seguro de si, que enfrenta sua própria inferioridade e que apesar de hesitar em alguns momentos, demonstra ser o inverso do inapto, ao cortejar a filha de seu patrão, a senhorita Annetta Maller. A cena do primeiro beijo, que demora a acontecer, ocorre no décimo segundo capítulo, mostra certa impetuosidade em seu caráter:

Ajoelhou-se na frente de Annetta e tentou segurar de novo sua mão. Parecia espontâneo, mas realmente tratava-se de uma audácia calculada. Ela começou a rir, mas aproximou sua 
cabeça da cabeça escura de Alfonso e nenhum dos dois teria sabido dizer como chegaram a beijar-se na boca pela primeira vez. ${ }^{114}$ (SVEVO, 1993, p.150, grifo nosso)

\section{$(\ldots)$}

Tinham agora dado um enorme passo à frente e não havia como voltar. Haviam falado e, o que era pior, Alfonso assistira à comoção que Annetta sentira, como qualquer pessoa fraca, tinha subitamente descoberto que o mais forte era ele. ${ }^{115}$ (SVEVO, 1993, p.151, grifo nosso)

Pelos termos grifados podemos perceber a coragem de Alfonso e também seu comportamento audacioso, mas calculado como ele próprio ressalta. E, mesmo antes do suicídio, Nitti demonstra ao leitor certa audácia e bravura ao enfrentar o temido patrão, o senhor Maller, por não concordar com a sua transferência de setor no banco:

- Eu não desejo - respondeu com raiva. - Eu quero, eu exijo ser enviado de volta à correspondência. Preciso poder progredir - e candidamente falou de sua difícil situação financeira.

Por seu firme propósito de defender-se com energia, dando a cada frase uma resposta pronta, Alfonso encontrava-se numa grande agitação, produzida pelo esforço de pensar intensamente para achar-se sempre preparado. (...) De hábito, quando algo inesperado lhe acontecia, ficava hesitante, calavase, abandonava o que tinha planejado antes e acabava se arrependendo de não ter sido mais decidido. Dessa vez o arrependimento seria de natureza bem diversa. Maller fora brusco e assim seria ele também. ${ }^{116}$ (SVEVO, 1993, p.324, grifo nosso)

\footnotetext{
${ }^{114}$ S'inginocchio dinanzi ad Annetta e cercò di riprenderle la mano. Era detto ed era agito bene con aspetto di spontaneità mentre realmente si trattava di un'audacia calcolata. Ella si mise a ridere, ma avvicinò la sua alla testa bruna di Alfonso e nessuno dei due avrebbe saputo dire come fossero giunti per la prima volta a baciarsi sulle labbra. Ibid., p.172.

${ }^{115}$ Avevano ora fatto un passo gigantesco innanzi e non c'era più via al ritorno. Avevano parlato e quello ch'era peggio Alfonso aveva assistito alla commozione da persona debole di Annetta, aveva improvvisamente scoperto di essere lui il più forte. Ibid., p.173.

116 - lo non voglio, - disse con stizza. - lo desidero, io prego di venir rimandato alla corrispondenza. Ho bisogno di poter avanzare, - e candidamente parlò della sua difficile situazione finanziaria. / Nel suo forte proposito di difendersi con energia dando ad ogni botta
} 


\section{$(\ldots)$}

- Pois muito bem - gritou Alfonso -, eu deixarei o emprego! - sentiu-se forte ao lembrar que o pior que the podia acontecer era perder o emprego. Continuou mais calmo, mas com o desejo de atingir e de ofender: - É natural que eu não possa permanecer num emprego onde sou perseguido sem razão... pelo menos, aparente.

- Darei ordens para que o ajudem em seu trabalho - disse Maller, cedendo logo.

O encontro deixou-o numa agitação terrível. Saiu insatisfeito da sala de Maller. Obtida a vitória, sentia muito claramente que não era a desejada, visto que não conseguira desfazer a desestima em que caíra aos olhos dos superiores do banco. ${ }^{117}$ (SVEVO, 1993, pp.324-325, grifo nosso)

Alfonso enfrenta o tão assustador chefe, o senhor Maller. Os termos grifados apontam um personagem determinado e ousado que consegue se impor diante do patrão. Alfonso foge, neste momento, totalmente à figura do empregado resignado, subalterno e inferior, que jamais ousaria subir ao mesmo pedestal do patrão para discutir.

una pronta risposta, Alfonso si trovava in una grande agitazione prodotta da quel suo sforzo di pensare intensamente per trovarsi preparato. (...) Di solito, quando gli tocava qualche cosa d'inaspettato rimaneva esitante, taceva, abandonando anche i piani fatti precedentemente, ciò che di spesso finiva col pentimento di non essere stato più risoluto. Questa volta il pentimento doveva essere di tutt'altra natura. Maller fu brusco e volle esserlo anche lui. lbid, p.385.

117 - Ebbene! - gridò Alfonso - io lascerò l'impiego! - E si sentì forte al rammentarsi che il peggio che gli potesse accadere era di rimanere senza impiego. Continuò più calmo, ma col desiderio di colpire e di offendere: - Naturalmente non posso rimanere in un impiego ove mi si perseguita senza cagione... almeno che appaia. (...) / -Darò ordine ch'ella venga aiutato nel suo lavoro, - disse Maller cedendo subito. (...) / Questo colloquio lo lasciò in un'agitazione terribile. Uscì dalla stanza di Maller insoddisfatto. Ottenuta la vittoria, sentiva con evidenza che non era quella la desiderata perché non gli era riuscito di togliere la disistima in cui era caduto agli occhi dei capi della banca. Ibid., pp.385-386. 
Tal passagem constitui-se no auge da força, da impetuosidade de Alfonso. O caráter inapto, débil parece não fazer parte de sua personalidade neste momento. Tal premissa justifica nossa também ousadia em dizer que a inaptidão no presente romance apresenta uma oscilação, iniciada com um decréscimo, que vai ganhando força, para depois sucumbir totalmente.

Um dos princípios da teoria mimética girardiana, é: "todos temos sempre um modelo que imitamos" (GIRARD, 2000, p. 85). Quando o narrador nos diz: "Maller fora brusco e assim seria ele [Alfonso] também", fica evidente que o comportamento de Nitti tem como modelo a postura do patrão. O modelo a ser imitado aqui é o de rispidez, grosseria.

O término da oscilação de sua inaptidão, que se apresenta como total forma de negação diante da vida, é seu suicídio. Para não duelar com o irmão de Annetta, por se sentir inferior a esse, Alfonso opta por sair de cena do palco dessa sociedade que para ele é egoísta e mesquinha, da qual ele não conseguiu reconhecimento nem integração. De acordo com Hermann Grosser, uma das principais características da narrativa do Novecento, será a representação do mundo como um espaço enigmático, no qual

o homem contemporâneo não parece mais reconhecer como naturais e humanos os lugares e contextos sociais em que vive, assim como não consegue mais realizar, de modo natural, os gestos e os atos mais comuns da vida cotidiana e "normal" (o motivo da inaptidão, da incapacidade de viver normalmente). ${ }^{118}$ (GROSSER, 1986, p.174, grifo nosso, tradução nossa)

\footnotetext{
118 l'uomo contemporaneo non sembra più riconoscere come naturali e umani i luoghi e i contesti sociali in cui vive, così come non riesce più a compiere in modo naturale i gesti e gli atti più comuni della vita quotidiana e "normale" (il motivo dell'inettitudine, dell'incapacità di vivere normalmente). In GROSSER, Hermann. Narrativa. Milano: Casa Editrice G. Principiato, 1986, p.174.
} 
Esse homem "inapto", incapaz de viver obedecendo às regras consideradas normais, por assim dizer, já não reconhece o ambiente em que vive, daí o estranhamento entre sujeito e seu mundo exterior. Alfonso diante de tal desconforto opta por renunciar à vida. Para Broccoli, o suicídio constitui-se em um gesto extremo de protesto à sociedade pérfida e corrompida em que ele vive (BROCCOLI, 1972, p.14):

Devia lutar com Federico Maller num embate ímpar, em que seu adversário teria todas as vantagens: o ódio e a habilidade. O que podia esperar? Só tinha uma saída para evitar aquele encontro em que faria um papel miserável e ridículo: o suicídio. ${ }^{119}$ (SVEVO, 1993, p.332, grifo nosso)

Nunca pensara no suicídio a não ser com o juízo alterado por ideias alheias. Agora aceitava-o não resignado, mas alegre. A libertação! Lembrava-se que até pouco tempo antes pensava de modo tão diferente e tentou acalmar-se, apurar se aquele sentimento de alegria que o arrastava até a morte não seria um produto da febre de que poderia estar tomado. Não! Ele raciocinava calmamente. Colocava mentalmente à sua frente todos os argumentos contra o suicídio, desde os morais, dos pregadores, até os dos filósofos mais modernos; faziam-no sorrir. Não eram argumentos, mas desejos, o desejo de viver.

Ele, ao contrário, sentia-se incapaz de viver. Alguma coisa, que muitas vezes procurara inutilmente compreender, tornava esse esforço doloroso, insuportável. Não sabia amar e não sabia sentir prazer; (...) Deixava a vida sem remorso. Era o caminho para tornar-se superior às suspeitas e aos ódios. Era essa a renúncia que ele sonhara. Era preciso destruir aquele organismo que não conhecia a paz; vivo, teria continuado a arrastá-lo à luta porque para isso fora feito. Não escreveria a Annetta. Iria poupá-la do incômodo e do perigo que aquela carta poderia representar para ela. ${ }^{120}$ (SVEVO, 1993, p. 333, grifo nosso)

\footnotetext{
${ }^{119}$ Doveva battersi con Federico Maller in una lotta impari nella quale il suo avversario aveva tutti i vantaggi: l'odio e l'abilità. Che cosa poteva sperare? Gli rimaneva soltanto una via per isfuggire a quella lotta in cui avrebbe fatto una parte miserabile e ridicola, il suicidio. In SVEVO, Italo. Romanzi e "continuazioni". Milano: Mondadori, 2006, pp.394-395.

120 (...) / Non aveva pensato mai al suicidio che col giudizio alterato dalle idee altrui. Ora lo accettava non rassegnato ma giocondo. La liberazione! Si rammentava che fino a poco prima
} 
Já no início da citação, o protagonista aponta as qualidades de seu adversário: o ódio e a habilidade. Habilidade essa que Alfonso parece não ter. Diante da situação, o único caminho vislumbrado por nosso herói problemático, que de acordo com Lukcás nasce do "alheamento em face do mundo exterior", é dar fim à sua "turbulenta" existência (LUKÁCS, 2002, p.66). Alfonso, típico sujeito sveviano encarna o indivíduo "vencido" da sociedade burguesa. Svevo, assim como fará Pirandello no mesmo período, colocam em cena esse sujeito problemático que já não consegue mais se integrar ao organismo social.

O suicídio como o próprio Alfonso pontua é sua libertação. Libertação de um mundo, no qual ele é incapaz de viver, pois "não sabe amar, não sabe sentir prazer" (SVEVO, 1993, p.333). A morte, não se pode esquecer, consiste, como bem notou Camerino, na renúncia definitiva da ação (CAMERINO, 1974, p.90). Tal renúncia pode ser lida ainda, segundo Moloney, como um ato de vontade; a autonegação seria uma forma vigorosa do sujeito afirmar-se (MOLONEY, 1998, p.56).

Outro ponto que merece destaque é o fato do personagem sveviano ser, basicamente, um eu pensante. Nos três romances, a parte cognitiva dos protagonistas é muito mais desenvolvida se comparada com a capacidade de

aveva pensato altrimenti e volle calmarsi, vedere se quel sentimento giocondo che lo trascinava alla morte non fosse un prodotto della febbre da cui poteva essere posseduto. No! Egli ragionava calmo! Schierava dinanzi alla mente tutti gli argomenti contro al suicídio, da quelli morali dei predicatori a quelli dei filosofi più moderni; lo facevano sorridere! Non erano argomenti ma desiderî, il desiderio di vivere. / Egli invece si sentiva incapace alla vita. Qualche cosa, che di spesso aveva inutilmente cercato di comprendere, gliela rendeva dolorosa, insopportabile. Non sapeva amare e non godere; (...) L'abbandonava senza rimpianto. Era la via per divenire superiore ai sospetti e agli odii. Quella era la rinunzia ch'egli aveva sognata. Bisognava distruggere quell'organismo che non conosceva la pace; vivo avrebbe continuato a trascinarlo nella lotta perché era fatto a quello scopo. Non avrebbe scritto ad Annetta. Le avrebbe risparmiato persino il disturbo e il pericolo che poteva essere per lei una tal lettera. Ibid., pp.395-396. 
agir. Note-se que Alfonso analisa "mentalmente à sua frente todos os argumentos contra o suicídio", o que o caracteriza como um ser não da ação, mas do pensar, ou da palavra, para dizê-lo com Bakhtin que afirma em sua obra que enquanto o herói épico age, o romanesco "adquire uma iniciativa ideológica e linguística que modifica a sua figura" (BAKHTIN, 2002, p.426). Desse modo, a palavra dirige a ação e a escolha pela não-ação e, no caso de Alfonso cristalizará sua história na renúncia definitiva da ação e da palavra (CAMERINO, 1974, p.90).

Nitti, conforme Del Missier que, de certa forma, retoma a teoria de Victor Brombert, é um personagem complexo e contraditório: pensa de um jeito e age de outro, quer e não quer, constrói e destrói, é calculista e ao mesmo tempo desinteressado, para citar algumas de suas características (DEL MISSIER, 1987, p.217). Sua identidade reflete o comportamento inquieto, indeciso do homem moderno à procura de seu autoconhecimento. Sua história poderia ser a história de qualquer sujeito real, que vence, que fracassa, que em determinados momentos é mais racional e em outros mais intuitivo ou instintivo. O que individualiza Alfonso parece ser justamente sua aguçada racionalidade, que por vezes o paralisa. Talvez essa característica tenha permitido à crítica sveviana classificá-lo como o "maior" inetto de Svevo, contudo acreditamos que Nitti ultrapassa sua inaptidão, mostrando-nos um retrato fidedigno de um sujeito da sociedade da qual ele faz parte. Um ponto é evidente, o protagonista de Una vita é inapto a acompanhar e entender as rápidas mudanças dessa sociedade burguesa, na qual ele não quer inserir-se, por isso decide renunciar à vida. 


\subsection{Il carnevale di Emilio ou a renúncia aos prazeres da vida?}

Assim como Una vita, o título original desse romance não era Senilità, mas II carnevale di Emilio. Se questionamos o primeiro título (Un inetto), escolhido por Svevo para seu primeiro romance, discordando dele, fazemos o mesmo aqui, por também acreditarmos que o título original (II carnevale di Emilio) não seria o mais adequado, pois não exprimiria a história vivida pelo "senil" Emilio Brentani. Senilità, a nosso ver, representa e caracteriza melhor seu protagonista, cuja senilidade existencial pode ser comprovada na narrativa. Beatrice Stasi afirma que a história do trintão Emilio Brentani pode e deve ser intitulada Senilità, uma vez que desde as primeiras páginas do livro é esse o diagnóstico de seu comportamento mental definido pelas trajetórias e limites de seu percurso existencial (STASI, 2009, p.79).

Para Eugenio Montale, importante por apresentar Svevo e a riqueza de sua obra à Itália, o esquema desse segundo romance demonstra-se "limitado" em sua superfície, sendo necessário um mergulho mais profundo para se compreender os personagens e as relações vividas entre eles (MONTALE, 1925, p.807).

Essa limitação apontada por Montale tem relação direta com a própria narrativa que apresenta pouca ação, poucos personagens, sendo a trama toda concentrada em Emilio Brentani, na sua irmã, Amália, no escultor Stefano Balli e na bela Angiolina Zarri. Tais personagens poderiam ser divididos em dois pares: Emilio e a irmã representam a inettitudine, a doença, a incapacidade de se adaptar à vida em sociedade; já Balli e Angiolina representam o dinamismo, a saúde, a capacidade — até certo ponto — de se adaptar a tal vida. A 
ressalva, até certo ponto, justifica-se na medida em que Balli mesmo com toda sua desenvoltura não consegue ser bem sucedido com sua arte e Angiolina mesmo com sua beleza ofuscante não consegue ascender socialmente.

De acordo com Caterina Verbaro a dialética da história é desmembrada a partir do desenvolvimento desses quatro personagens principais que

Encarnam e representam com intensidade marcas existenciais, criando uma trama romanesca compacta e fechada. Emilio e Amalia Brentani, Angiolina Zarri e Stefano Balli, entram imediatamente e quase simultaneamente em cena, delineando com os próprios caráteres 0 desenvolvimento da ação. ${ }^{121}$ (VERBARO, 1997, p.51, tradução nossa)

À leitura de Verbaro soma-se a posição de Montale, ao ressaltar a escassez de eventos no romance, sendo que a tensão narrativa está justamente na focalização dos movimentos interiores, na sondagem dos sentimentos a que esses personagens são expostos durante a narrativa.

De acordo com Bruno Maier, a senilidade é importante não apenas por indicar as características primordiais do senhor Brentani, mas de todos os protagonistas svevianos que se caracterizam, sobretudo, pela prevalência das faculdades teóricas sobre as práticas, na constante vocação introspectiva, na condição efetivamente ou virtualmente patológica, e no pertencimento de uma dinastia de contempladores e de vencidos pela vida (MAIER, 1980, p.76). Tal pressuposto nos remete ao modo como Svevo e também, Pirandello deslocam

\footnotetext{
${ }^{121}$ Incarnano e rappresentano con forza delle cifre esistenziali, creando un ordito romanzesco compatto e serrato. Emilio e Amalia Brentani, Angiolina Zarri e Stefano Balli, entrano immediatamente e quasi contemporaneamente in scena, delineando coi propri caratteri lo sviluppo dell'azione. In VERBARO, Caterina. Italo Svevo. Soveria Mannelli/Calabria: Rubbettino, 1997, p.51.
} 
a figura do "vinto" verghiano ${ }^{122}$ ao mundo burguês. Emilio Brentani, assim como Alfonso, será um ser de pensamentos e não de ação. À diferença do senhor Nitti, Brentani encontra-se nel mezzo del cammin de sua pobre existência, com 35 anos. Se, de certa forma, Alfonso busca inserir-se em uma sociedade, que se constitui no próprio espaço do romance (note-se que a maior parte da narrativa passa-se no Banco e na casa Maller, ou seja, o primeiro espaço é burocrático e o segundo um espaço que representa a alta burguesia), Emilio Brentani aparenta estar integrado a ela, ainda que ele próprio se sinta à sua margem.

Como já foi dito anteriormente, o protagonista do segundo romance sveviano, levava uma vida pacata, marcada pela inércia ao lado da única irmã, "alguns anos mais nova do que ele, porém mais velha pelo caráter ou talvez pelo destino"123 (SVEVO, 1982, p.11). Sua vida é alvo de uma reviravolta quando ele conhece a bela senhorita Angiolina Zarri. Não se sabe como se dá e em que circunstâncias o casal se conhece, pois a narrativa não nos apresenta elementos para tanto; temos apenas o que seria um primeiro encontro, que traz à tona uma das características do personagem inapto, sobre

\footnotetext{
${ }^{122}$ Tanto Svevo quanto Pirandello retratam a questão do personagem que se vê em um "semsaída" existencial. Tal personagem, que figura na literatura entre o fim do século XIX e início do século XX, delineado por autores de escolas literárias e universos narrativos muito diferentes, parece ser transportado do campo, do mundo antigo, fechado e marcado pela tradição oral, para o ambiente urbano, ligado ao progresso, ao novo e à cultura letrada, insuficientes, no entanto para fornecer soluções a esse típico personagem "inetto", enlcausurado em seu mundo de expectativas fantasiosas, irreais e irrealizáveis na realidade do ambiente burguês. Perdidos e incapazes de mudar seus destinos, esses personagens remetem àqueles do "ciclo dei vinti" de Giovanni Verga.

${ }^{123}$ di qualche anno più giovane di lui, ma più vecchia per carattere o forse per destino. In SVEVO, Italo. Romanzi e "continuazioni". Milano: Mondadori, 2006, p. 403.
} 
a qual discorremos anteriormente, ou seja, a capacidade pensante. Isso pode ser comprovado já nos primeiros parágrafos:

Desde logo, com as primeiras palavras que the ocorreram, quis avisá-la de que não pretendia comprometer-se numa relação muito séria. Falou-lhe aproximadamente assim: Gosto muito de você, mas para o seu bem temos de agir com a máxima cautela." As palavras saíam tão prudentes que era difícil crer fossem ditas por amor de outrem, e, se um pouco mais sinceras, deviam soar da seguinte maneira: "Gosto de você, mas na minha vida você nunca vai passar de um brinquedo. Tenho outros deveres, a minha carreira, a família..."

A família? Uma irmã única, que não o incomodava nem física nem moralmente, pequena e pálida, alguns anos mais nova que ele, porém mais velha pelo caráter ou talvez pelo destino. Dos dois, ele é que era o egoísta, o jovem; ela vivia para ele como essas mães que se esquecem de si mesmas, mas isto não o impedia de referir-se a ela como um outro destino importante unido ao seu e que pesava sobre ele, e assim, sentindo-se curvar-Ihe os ombros tamanha responsabilidade, ia atravessando a vida cauto, deixando de parte todos os perigos, mas também todo o deleite, toda a felicidade. Aos trinta e cinco anos ainda encontrava na alma a chama insatisfeita do prazer e do amor, e já a amargura de não os haver desfrutado, enquanto que no cérebro um grande medo de si mesmo e da fraqueza de seu próprio caráter, de que na verdade mais suspeitava do que conhecia por experiência. ${ }^{124}$ (SVEVO, 1982, pp.11-12, grifo nosso)

\footnotetext{
${ }^{124}$ Subito, con le prime parole che le rivolse, volle avvisarla che non intendeva compromettersi in una relazione troppo seria. Parlò cioè a un dipresso e così: - T'amo molto e per il tuo bene desidero ci si metta d'accordo di andare molto cauti -. La parola era tanto prudente ch'era difficile di crederla detta per amore altrui, e un po' più franca avrebbe dovuto suonare così: - Mi piaci molto, ma nella mia vita non potrai essere giammai più importante di un giocattolo. Ho altri doveri io, la mia carriera, la mia famiglia./ La sua famiglia? Una sola sorella non ingombrante né fisicamente né moralmente, piccola e pallida, di qualche anno più giovane di lui, ma più vecchia per carattere o forse per destino. Dei due, era lui l'egoista, il giovane; ella viveva per lui come una madre dimentica di se stessa, ma ciò non impediva a lui di parlarne come di un altro destino importante legato al suo e che pesava sul suo, e così, sentendosi le spalle gravate di tanta responsabilità, egli traversava la vita cauto, lasciando da parte tutti i pericoli ma anche il godimento, la felicità. A trentacinque anni si ritrovava nell'anima la brama insoddisfatta di piaceri e di amore, e già l'amarezza di non averne goduto, e nel cervello una grande paura di se stesso e della debolezza del proprio carattere, invero piuttosto sospettata che saputa per esperienza. Ibid., p. 403.
} 
A narrativa, iniciada com o misterioso e conturbado relacionamento entre Emilio e Angiolina, apresenta um discurso mais "técnico" e direto, como bem notou Giovanna Miceli-Jeffries, em seu estudo sobre Senilità de Svevo e Un amore di Buzzati, evidenciando certa mercantilização da mulher-objeto (MICELI-JEFFRIES, 1990, p.357). Esses primeiros parágrafos parecem mostrar um Emilio bastante racional, que deve "agir com a máxima cautela", uma vez que não pretende assumir nenhum compromisso com a moça, que "nunca" passará de um "brinquedo" em sua vida, pois ele tem outros deveres, como a carreira e a família. Bruno Maier afirma que Emilio propõe a Angiolina de ser sua amante, em/com termos de extrema crueldade (MAIER, 1980, p.82).

Todavia tal comportamento de Emilio não se sustentará; no decorrer de sua história entraremos em contato com um sujeito bastante sentimental, um apaixonado tímido e "romântico", como se fosse um estudante enamorado pela mais bela colega de sala (MAIER, 1980, p.82).

Sua personalidade débil é ressaltada pela sequência de palavras "fraqueza de seu próprio caráter". Assim como em Una vita, percebemos aqui a influência de Schopenhauer, quando o narrador diz que o senhor Brentani , "ia atravessando a vida cauto, deixando de parte todos os perigos, mas também todo o deleite, toda a felicidade". Tal passagem é uma clara referência à teoria do filósofo alemão que, grosso modo, diz que são nossas vontades e desejos que nos levam ao sofrimento. Se sufoco minhas vontades estou propenso a não sofrer, contudo isso equivale a não enfrentar os desafios e belezas da vida, a deixar de lado "todos os perigos, mas também todo o deleite, toda a felicidade". 
Apesar de Emilio querer impor-se à jovem moça como um homem experiente, seguro de si, a ponto de lhe propor uma aventura afetiva, na qual ela não passará de um brinquedo, sabemos que Brentani é um ingênuo, como bem o descreve seu melhor amigo, o escultor Stefano Balli; é um verdadeiro homem "balzaquiano", inexperiente no amor e que terminará vítima da formosa e astuta Angiolina, que, pode até ser una popolana, não ter o conhecimento livresco de Emilio, mas é especialista na grande escola chamada vida.

No decorrer da narrativa, veremos que o verdadeiro brinquedo, o objeto mercantilizado nessa relação não será a moça, mas Emilio. O controle, que inicialmente parece pertencer a Brentani, será transferido a Angiolina, que manipulará a relação e o amante a seu bel prazer. Desse modo, o uso da palavra "brinquedo" pelo narrador, caracteriza a ironia, por vezes mordaz, que marca a obra sveviana.

A relação que deveria ser para Brentani uma aventura casual, algo que trouxesse vida e "movimento" à sua inércia existencial, consolida-se como um tormento, uma verdadeira prisão afetiva. Tal paixão não cumprirá seu papel, isto é, tirar Emilio de seu limbo existencial; nem mesmo a vital Angiolina poderá alegrar a vida monótona do protagonista. Falta a Brentani coragem para assumir tal relação ou mesmo para enxergar o verdadeiro caráter da moça, e assim desfrutar, sem culpa, dos prazeres carnais que ela pode propiciar-Ihe:

...começou a compadecer-se dela por ter caído nas mãos de um homem como ele, pobre de dinheiro e até de outras coisas, como de energia e coragem. Porque, se tivesse coragem - e sua voz tremeu de emoção ao fazer-lhe pela primeira vez uma declaração de amor mais séria que as precedentes -, ele teria tomado sua loura entre os braços, tê-la-ia apertado contra o 
peito e a levaria consigo vida afora. Mas, ao contrário, ele não se sentia com força para tanto. Oh, a miséria a dois era uma coisa horrível; era a escravidão, a mais dolorosa de todas. Temia-a por ela e por ele. ${ }^{125}$ (SVEVO, 1982, p.28, grifo nosso)

Os termos grifados retratam a inércia de Emilio que ele parece consciente em não querer enfrentar. A ironia do narrador para com o protagonista também fica evidente na fala "começou a compadecer-se dela por ter caído nas mãos de um homem como ele". Sabemos que na verdade é Emilio quem deveria compadecer-se de si mesmo, por ter se apaixonado pela astuta e independente Angiolina Zarri.

Para Norberto Cacciaglia, Angiolina apresenta uma personalidade multifacetária, que busca a "alforria" de sua origem social. Para tanto, ela usará as armas que tem, ou seja, beleza, juventude, desenvoltura, cinismo. Cacciaglia afirma que a moça não é totalmente mentirosa; sua estratégia consiste em esconder-se atrás de suas meias verdades. Emilio, ao contrário, mente a si próprio, ao construir uma relação idealizada (CACCIAGLIA, 1992, pp.317-318). Ele cria "conscientemente" e refugia-se em um mundo de sonhos e fantasias, com intuito de esconder-se da cruel realidade que está na frente de seu nariz, e que podemos comprovar através de várias passagens, como por exemplo:

(...) Dias antes ouvira contar um fato que o comovera bastante. Um astrônomo alemão, havia já uns dez anos, vivia no próprio observatório, num dos picos mais altos dos Alpes, entre as

${ }_{125}$... si mise a compiangerla d'essere caduta fra le mani di un uomo come lui, povero di denaro e anche di qualche cosa d'altro, energia e coraggio. Perché se egli avesse avuto del coraggio, - e facendole per la prima volta una dichiarazione d'amore più seria di tutte le precedenti, la sua voce si alterò in una grande commozione, - egli si sarebbe presa la sua bionda fra le braccia, se la sarebbe stretta al petto e l'avrebbe portata attraverso alla vita. Ma invece egli non si sentiva da tanto. Oh, la miseria in due era una cosa orribile; era la schiavitù, la più dolorosa di tutte. La temeva per se e per lei. Ibid., p. 417. 
neves eternas. A povoação mais próxima situava-se a cerca de um quilômetro abaixo na montanha, e de lá uma menina de seus doze anos trazia-lhe provisões. Naqueles dez anos de subidas e descidas diárias, a menina foi-se transformando numa jovem forte e bela, com quem o cientista acabou por casar-se. O casamento foi celebrado no vilarejo e os recémcasados subiram em viagem de núpcias para o observatório da montanha. Entre os braços de Angiolina pensava agora na história; era assim que gostaria de possuí-la, a mil metros de distância de qualquer outro homem; assim - desde que lhe fosse possível, como o astrônomo, continuar a dedicar a vida aos mesmos objetivos - seria capaz de unir-se definitivamente a ela, sem reservas. - E você - perguntou com impaciência, já que ela não conseguia perceber a razão por que lhe contra essa história -, você não gostaria de ir lá para cima comigo ? ${ }^{126}$ (SVEVO, 1982, pp.61-62)

Tal excerto evidencia o desejo de Emilio em refugiar-se em um lugar não só distante a "mil metros" de outros homens, mas longínquo o suficiente da vida em sociedade. Se Alfonso buscava refúgio na tranquilidade do campo, Emílio vislumbra uma vida a dois, idealizada em uma alta montanha, que nos remete a uma torre em um castelo remoto, da qual o casal, após enfrentar vários obstáculos se casa e vive feliz para sempre. O tom romântico é quebrado com a postura gélida da amante, que destoa ironicamente do discurso idealizado e fantasioso do senhor Brentani.

\footnotetext{
${ }^{126}$ (...) Giorni prima egli aveva sentito raccontare un fatto che l'aveva assai commosso. Un astronomo tedesco, da una diecina di anni, viveva nel suo osservatorio, su una delle punte più alte delle Alpi, fra le nevi eterne. II più vicino villaggio era situato un migliaio di metri sotto ai suoi piedi, e di là gli veniva portato giornalmente il cibo da una fanciulla dodicenne. Nei dieci anni, a mille metri il giorno di salita e di discesa, la fanciulla era divenuta grande e forte e bella, e lo scienzato ne fece sua moglie. II matrimonio s'era celebrato poco tempo prima nel villaggio, e, per viaggio di nozze, gli sposi erano saliti insieme alla loro abitazione. Fra le braccia d'Angiolina egli vi ripensò; così avrebbe voluto ora possederla, a mille metri di distanza da qualunque altro uomo; così - dato che gli fosse stato possibile come all'astronomo, di continuare a dedicare la vita ai medesimi scopi - sarebbe stato capace di legarsi definitivamente a lei, senza riserve. - E a te - domandò con impazienza visto ch'ella non capiva ancora perché le venisse raccontata quella storiella, $-\mathrm{e}$ a te piacerebbe di venir a stare lassù, con me? Ibid., pp. 444-445.
} 
O protagonista pela primeira vez cogita a ideia de casar-se com a amante, mas tal atitude não é levada a sério pela moça, pois ela sabe que se trata de mais um delírio de Emílio. Assim como Zeno nunca chegará ao último cigarro, Brentani não conseguirá entregar-se à sua paixão e muito menos vencer sua inércia que terminará por se cristalizar em sua renúncia à vida plena, aprisionando-se em uma senilidade existencial.

Brentani, como destacou Marzia Vicentini, "está consciente do engano e da degradação a que esta relação o leva, mas prefere auto enganar-se porque, sem esta ilusão, sua vida recairia na tristeza opaca de sempre" (VICENTINI, 1984, p.106). Logo após o melhor amigo, o escultor Stefano Balli, relatar que vira Angiolina acompanhada, muito à vontade, por outro homem, o chapeleiro, Emilio demonstra certa consciência de que está sendo traído e de que idealizara uma mulher que não existe:

Ele sentou-se sobre um murinho e procurou de propósito argumentos para acalmar-se. A vê-lo nesse estado poder-seia acreditar que nessa noite ele tivesse conhecimento da traição de uma mulher fiel. Olhou para as próprias mãos feridas: "Estas feridas eu não as tinha antes", pensou. Ela nunca o havia tratado dessa forma. Talvez todo esse afã e essa dor preludiassem a cura. Mas pensou, doloroso: "Se a tivesse possuído não sofreria tanto." Se tivesse querido, querido com vontade, ela teria sido sua. Em vez disso, seu único desejo foi introduzir em suas relações um idealismo que acabara por torná-lo ridículo até mesmo aos próprios olhos.

Ergueu-se do murinho mais calmo, porém mais abatido do que quando se sentara. Cabia-lhe toda a culpa. Ele é que era um indivíduo estranho, doentio, e não Angiolina. E essa conclusão aviltante acompanhou-o até em casa. ${ }^{127}$ (SVEVO, 1982, p.106, grifo nosso)

\footnotetext{
${ }^{127}$ Egli sedette su un muricciuolo e cercò di proposito degli argomenti per calmarsi. A vederlo in quello stato si sarebbe potuto credere che quella sera egli fosse stato avvisato del tradimento di una donna fedele. Guardò le proprie mani ferite: "Queste ferite non c'erano prima" pensò. In
} 
Os termos em destaque corroboram, inicialmente, com a ironia do narrador que pode ser vista nas expressões: "traição de uma mulher fiel". Se a mulher fosse fiel não existiria traição, desse modo o jogo semântico entre "traição" e "fiel" causa um divertido estranhamento ao leitor, que neste ponto da narrativa, sabe que se trata de mais uma ironia do narrador para com Emilio. Na sequência, vale ressaltar a caracterização do protagonista como inapto, uma vez que se [ele] "tivesse querido, querido com vontade, ela teria sido sua". Tal passagem denota a inércia de Brentani, que parece atuar como uma justificativa para seu fracasso, pois se ele fracassa por não fazer, por não ter vontade, daí a ilusão de que poderia ter conseguido permanece. Por outro lado, se ele tentar, rompendo sua inaptidão, e mesmo assim fracassar a frustração será maior. Brentani, Nitti e Zeno, em alguns momentos, parecem ficar paralisados diante do medo do fracasso. Nitti prefere se matar a morrer derrotado em um duelo, já os outros protagonistas ainda que não cheguem a uma atitude tão radical, são feitos do mesmo "barro". Desse modo, poderíamos dizer que o medo do fracasso é uma das principais características da inaptidão desses protagonistas.

De acordo com Lavagetto, Svevo, e aqui preferimos usar narrador, ao invés de Svevo (como é utilizado pelo crítico), trata Emílio com extrema

quel modo ella non l'aveva ancora trattato. Forse tutto quell'affanno e quel dolore: "Se l'avessi posseduta non soffrirei tanto". Se egli avesse voluto, voluto energicamente sarebbe stata sua. Invece era stato solo intento a mettere in quella relazione un'idealità che aveva finito col renderlo ridicolo anche ai propri occhi. / S'alzò da quel muricciuolo più quieto ma più affranto di quando vi si era seduto. Tutta la colpa era sua. Era lui l'individuo strano, l'ammalato, non Angiolina. E questa conclusione lo accompagnò fino a casa. Ibid., pp. 481-482. 
crueldade, usando predicados desumanos e ressaltando suas carências. O narrador reforça, a todo o tempo, o caráter covarde e ridículo do protagonista que não consegue integrar-se à vida. Brentani apresenta uma personalidade remissiva que revela, segundo Lavagetto, uma particular resistência ao real, sendo que nada consegue modificá-la. Ele constrói, incessantemente, um retrato improvável de Angiolina, que ela própria se encarrega de estilhaçar (LAVAGETTO, 1986, pp.13-14). Nem mesmo a doença da irmã, inconsciente em seu leito de morte, faz Emilio encarar a realidade que o circunda. Ao invés de assistir a irmã à beira da morte, ele prefere ir ao último encontro com sua amante:

(...) - Vou agora ao meu último encontro com Angiolina. - De fato, porque não? Viva ou morta Amalia o separara para sempre da amante, mas por que não iria dizer a Angiolina que queria romper definitivamente todas as relações com ela? $O$ coração expandiu-se de alegria ante essa última entrevista. Sua presença no quarto não favorecia ninguém, ao passo que indo ao encontro de Angiolina estaria fazendo um holocausto a Amalia. A Balli que, espantado com aquelas palavras, procurava dissuadi-lo de seu intento, disse que ia ao encontro porque queria aproveitar-se de seu estado de ânimo para livrarse para sempre de Angiolina. ${ }^{128}$ (SVEVO, 1982, p.239, grifo nosso)

Emílio diz que se tratará do último encontro com a bela amante. Brentani atribui a separação à irmã, uma vez que é incapaz de encarar a realidade e a verdadeira personalidade de Angiolina; sem coragem para assumir os fatos, ele

128 (...) - lo adesso andrò all'ultimo appuntamento con Angiolina -. Infatti, perché no? Viva o morta, Amalia lo avrebbe diviso per sempre dall'amante, ma perché non sarebbe andato a dire ad Angiolina che voleva rompere definitivamente ogni relazione con lei? Gli si aperse il cuore alla gioia di quell'ultimo abboccamento. La sua presenza in quella stanza non giovava a nessuno, mentre andando da Angiolina egli portava subito un olocausto ad Amalia. Al Balli che, meravigliato di quelle parole, cercarva di distoglierlo dal suo proposito, egli disse che andava all'appuntamento perché voleva approfittare di quel suo stato d'animo per liberarsi per sempre da Angiolina. Ibid., p.595. 
precisa de um álibi, de alguém que assuma a culpa para o término dessa relação. A ideia fixa de Emilio em se encontrar com a amante é reprovada por seu melhor amigo, o escultor Balli:

Stefano não acreditou; parecia ouvir o Emilio de sempre, em sua fraqueza, e quis fortalece-lo, contando-lhe que nesse dia mesmo fora obrigado a expulsar Angiolina do ateliê. Disseo com palavras tais que não podiam deixar dúvidas acerca do motivo.

Emilio empalideceu. Oh, sua aventura ainda não acabara. Renascera agora ali mesmo, junto ao leito da irmã. Angiolina traía-o mais uma vez de forma execrável. (...) - Por favor disse com uma veemência que não tentou abrandar -, conteme o que aconteceu.

Balli protestou: - Além da vergonha de ter bancado uma vez na vida o casto São José, não quero também a de registrar para a posteridade todos os pormenores de minha aventura. Você, porém está totalmente perdido, se num dia como este ainda pensa nessa mulher. ${ }^{129}$ (SVEVO, 1982, pp.239-240, grifo nosso)

O escultor parece perplexo diante do comportamento de Emilio, reforçando a fraqueza e o imutável caráter inapto do amigo. Nem mesmo a confissão de Balli de que Angiolina tentara seduzi-lo, faz com que Brentani mude de ideia. A incapacidade de Emilio em encarar a realidade é enfatizada ainda mais pelo amigo através do comentário: "Você, porém está totalmente

\footnotetext{
${ }^{129}$ Stefano non gli credette; gli pareva di sentir parlare il solito debole Emilio e gli parve di renderlo più forte raccontandogli che quel giorno stesso egli era stato obbligato di scacciare Angiolina dallo studio. Lo disse con parole che non potevano lascirare dubbio sul motivo. I Emilio impallidì. Oh, la sua avventura non era ancora morta. Rinasceva proprio là, al letto della sorella. Angiolina lo tradiva un'altra volta in modo inaudito. (...) - Te ne prego - disse con un calore che non tentò di mitigare - raccontami quello che è avvenuto. / II Balli portesto: - Oltre alla vergogna di aver dovuto fare una volta in mia vita da casto Giuseppe, non voglio mica avere anche quella di consegnare alla storia tutti i particolari della mia avventura. Tu però sei definitivamente perduto, se in una giornata simile vai ancora col pensiero a quella donna. Ibid., pp. 595-596.
} 
perdido, se num dia como este ainda pensa nessa mulher" (SVEVO, 1982, p.240).

Nem mesmo o estado terminal da irmã consegue fazer Emilio desistir de ver Angiolina, pela última vez. Entre seus argumentos para ir ao encontro, ele diz que precisa romper com a bela amante, um sacrifício que deve ser feito em nome da irmã:

Angiolina veio-lhe ao encontro no passeio de Sant'Andrea. Ao vê-lo, exclamou com grande irritação - uma nota discordante, dolorosa no estado de espírito de Emilio: - Já estou aqui há meia hora. Estava a ponto de ir embora.

Ele, docilmente, levou-a para junto do poste e a fez ver o mostrador do relógio que assinalava precisamente a hora combinada do encontro.

- Então fui eu que me adiantei - disse ela, não muito mais paciente. Enquanto Emilio estudava a maneira de dizer-Ihe que esse seria o seu último encontro, ela parou e disse-lhe: - Além do mais tenho mesmo de ir. (...)

Emilio foi arrancado da análise que sem cessar continuava a fazer de si mesmo, e passou a observá-la; (...) Chamou-lhe a atenção o fato de que estava vestida com mais capricho que de hábito. (...)

- Ouça, quero dizer-Ihe a verdade - disse ela, (...) - Recebi um telegrama de Volpini informando-me de sua chegada. Não sei o que vai querer de mim; mas o certo é que a essa hora já deve estar lá em casa. ${ }^{130}$ (SVEVO, 1982, p.244, grifo nosso)

\footnotetext{
${ }^{130}$ Angiolina gli venne incontro dal viale di Sant'Andrea. Vedendolo esclamò con grande stizza - una stonatura dolorosa nell stato d'animo di Emilio: - Son qui da mezz'ora. Ero in procinto di andarmene. / Egli, dolcemente, la trasse accanto ad un fanale e le fece vedere l'oriuolo che segnava precisamente l'ora subita per l'appuntamento. / - Allora mi sono ingannata - disse ella, non molto più dolcemente. Mentre egli andava studiando il modo con cui dirle che quello sarebbe stato l'ultimo loro incontro, ella si fermò e gli disse: - Per questa sera dovresti lasciarmi andare. (...) / Egli fu strappato all'indagine che sempre continuava su se stesso e la guardò, la osservò; (...) Lo colpì inoltre di trovarla vestita con maggior accuratezza del solito. (...) / - Senti, voglio dirti tutto - disse lei (...) - Ho ricevuto un dispaccio dal Volpini con cui m'annunzia il suo arrivo. Non so che cosa egli voglia da me; ma a quest'ora, certo, si trova già a casa mia. Ibid., pp. $599-600$.
} 
Note-se, inicialmente, a indiferença de Angiolina por Emilio, que é dominado por uma grande dor em seu estado de espírito, mas nem por isso deixa de ser dócil e subalterno com a moça. Emilio hesita e reflete antes de dizer o que pretende, mostra-se inseguro com as palavras, característica típica do personagem inapto, porém a amante é mais rápida e insensível ao dizer que precisa ir embora. Ela, mais uma vez, usa de seus artifícios e dissimulação.

Angiolina diz que precisa encontrar o alfaiate Volpini, seu suposto exnoivo, que retornara após o próprio Emilio escrever-Ihe uma carta assinada pela senhorita Zarri pedindo explicações sobre o pretenso rompimento deste e as acusações dirigidas ao caráter duvidoso da moça. Emilio parece, pela primeira vez, reconhecer que a moça não diz a verdade:

Ela mentia, não podia haver dúvida. Volpini a quem, de manhã, ele escrevera aquela carta, não podia, antes de recebê-la, chegar assim contrito para pedir perdão. Perturbado, riu-se triste: - Como? A pessoa que lhe escreveu aquela carta ontem vem hoje retirar tudo pessoalmente e até avisa por telegrama a sua chegada? (...)

Ela sorriu, ainda segura de si: - Ah, com certeza Sorniani Ihe contou que me viu, na noite atrasada, já tarde na rua em companhia de um senhor? (...) - Ele não a ouvia... Depois continuou: - Pena que eu tenha esquecido em casa o telegrama. Mas se você não quer acreditar, tanto pior. (...)

- É fácil compreender! - disse Emilio, rindo com raiva. Hoje você tem outro encontro. Pois vá a ele! Alguém está à sua espera.

- Pois bem, se você julga isso de mim, é melhor mesmo que eu me vá! - Falava decidida, mas não se moveu. ${ }^{131}$ (SVEVO, 1982, p.245, grifo nosso)

${ }^{131}$ Ella mentiva, non v'era alcun dubbio. II Volpini cui, nella mattina, egli aveva scritta quella lettera, eccolo che, prima di riceverla, arrivava, contrito, a chiedere scusa. Sconvolto, rise trieste: - Come? Colui che ieri ti scrisse quella lettera, oggi capita a ritirarla in persona ed anzi ti avvisa la sua venuta telegraficamente. (...) / Ella sorrise ancora sicura di sé: - Ah, a te è stato raccontato dal Sorniani, che due sere fa m'ha visto a ora tarda sulla via, accompagnata da un signore? (...) - Egli non l'udiva... - Poi continuò: - Peccato che ho dimenticato a casa il 
Emilio a questiona e demonstra-se seguro acerca das mentiras de Angiolina, que ainda empenha-se em convencê-lo de sua inocência. Todavia, não consegue persuadir o ingênuo Emilio, que fora enganado durante todo o relacionamento, mas que diante da doença da irmã é obrigado a encarar a verdadeira índole de Angiolina, que ele distorcera e ocultara através de suas fantasias.

Tal encontro será marcado por uma tensão ainda maior, constituindo-se no ápice da relação entre eles e também da narrativa. O comportamento doce e inocente de Emilio dará lugar a uma postura brutal com a amante:

(...) Agarrou-a pelo braço para impedi-la de andar, apoiou-se ao poste que tinha por detrás de si e aproximou o rosto transtornado de sua rósea e tranquila face. - Esta é a última vez que nos vemos! - gritou-lhe.

- Está bem, está bem - disse ela ocupada apenas em libertar-se do agarro que Ihe fazia mal.

- E sabe por quê? Por que você é uma... - Hesitou um instante, depois gritou a palavra que até mesmo à sua ira parecia excessiva, gritou-a vitorioso, triunfando sobre sua própria dúvida.

- Largue-me - gritou ela transtornada pela raiva e pelo medo -, largue-me ou grito por socorro. ${ }^{132}$ (SVEVO, 1982, p.246, grifo nosso)

dispaccio. Ma se non mi vuoi credere, tanto peggio. (...) / - È facile capirlo! - disse Emilio ridendo rabbiosamente. - Oggi tu hai un altro appuntamento. Vattene presto! C'è qualcuno che t'attende. I - Ebbene, se credi di me questa cosa, è meglio ch'io me ne vada! - Parlava risoluta, ma non si mosse. Ibid, pp. 600-601.

132 (...) L'afferrò per le braccia per impedirle di andare, s'appoggiò al fanale che aveva dietro di sé e avvicinò la propria faccia sconvolta a quella di lei rosea e tranquilla. - Ė l'ultima volta che ci vediamo! - urlò. / - Sta bene, sta bene - disse ella occupata soltanto a liberarsi di quella stretta che le faceva male. / - E sai perché? Perché tu sei una... - Esitò un istante, poi urlò quella parola che persino alla sua ira era sembrata eccessiva, la urlò vittorioso del suo stesso dubbio. / - Lasciami - gridò ella sconvolta dalla rabbia e dalla paura - lasciami o chiamo aiuto. Ibid., p.601. 
Emilio parece perder a razão, seu mundo de sonhos e fantasias diante da bela Ange, figura que só existiu em sua mente, desmorona-se. O sujeito racional parece dar lugar ao instintivo e animal quando Emilio agarra o braço da amante. Brentani, já não pode mais esquivar-se da verdadeira personalidade da amante, é obrigado a encarar as mentiras que ele próprio construiu para relacionar-se com uma moça de classe social mais baixa, de caráter duvidoso, faceiro e interesseiro.

O protagonista tem dificuldades em dizer com todas as letras o porquê da separação. Para ele é muito doloroso reconhecer que a amante em nada se assemelha com a doce e pura Ange que ele construíra para poder envolver-se. A primeira tentativa de verbalizar o caráter de sua amante é frustrada, somente na segunda ele consegue gritar aos quatro ventos e com todas as letras o que Angiolina é na verdade:

- Você é uma puta! $!^{133}$ - gritou de novo, vendo que conseguia irritá-la e assim renunciar à agressão física. - E pensa que eu não tinha percebido há muito tempo a espécie de pessoa que você é? Quando encontrei você vestida de criada, na escada de sua casa - relembrou aquela noite em todos os seus pormenores - com aquele xale todo colorido na cabeça, os braços ainda quentes na cama, pensei logo na palavra que agora the disse. Mas preferi não dizê-la e continuar aproveitando-me de você como fizeram os outros todos, Leardi, Giustini, Sorniani e ... e... Balli.

- Ah, o Balli! - riu ela, gritando para fazer-se ouvir através do ruído do vento e da voz de Emilio. - Ele se gaba, mas não conseguiu nada.

133 Importante destacar que Ivo Barroso, o tradutor do romance que escolhemos como referência, optou por usar a palavra "puta", no entanto na versão original, tal vocábulo não é utilizado. O estilo linguístico utilizado no texto é mais sutil, e deixa implícita tal palavra ofensiva, através do uso das reticências. 
- Só se foi porque não quis, o paspalhão, por respeito a mim, como se tivesse importância para mim que você fosse possuída por um homem a menos, sua ... - e pela terceira vez cuspiu-Ihe no rosto aquela palavra.

\section{$(\ldots)$}

Ela agora, aparentemente exausta, demonstrava medo; o rosto empalidecido, os olhos fitavam-no com um ar de quem pede compaixão. (...) Com um gesto rápido, ela libertou-se e se pôs a correr desesperadamente. Estava mentindo ainda desta vez! Ele não saberia alcançá-la; abaixou-se, procurou uma pedra, e não encontrando, apanhou um punhado de cascalho que atirou em sua direção. $O$ vento ajudou e algum seixo deve ter-lhe acertado, pois ela soltou um grito de espanto; outras foram cerceadas pelos ramos secos das árvores e produziram um rumor muito desproporcional à ira com que ele as atirara. ${ }^{134}$ (SVEVO, 1982, pp.246-247, grifo nosso)

Brentani, que até então mantivera um discurso culto, moralizante, pois pretendia educar a amante, faz uso de uma palavra ofensiva, vulgar para atingir a moça. Embora a índole de Angiolina seja evidente ao leitor, chama atenção o fato da mulher nessa sociedade machista e capitalista, ser comparada a uma simples mercadoria a ser possuída, conforme as próprias palavras usadas por Emilio.

\footnotetext{
134 - Tu sei una... - replicò egli che finalmente, vedendola irritata, poteva rinunziare a percuoterla. - Ma credi dunque che io da lungo tempo non mi sia accorto con chi avuto da fare? Quando ti trovavo vestita da serva, sulle scale di casa tua - rammentò quella sera in tutti $i$ particolari - con quello scialle grezzamente colorito sulla testa, le braccia calde di alcova, pensai subito la parola che ora t'ho detta. Non volli dirtela e giuocherellai con te come facevano tutti gli altri, Leardi, Giustini, Sorniani e... e... il Balli. / - II Balli! - rise ella urlando per farsi udire attraverso al rumore del vento e della voce d'Emilio. - II Balli si vanta; non è vero niente. / Perchè lui non volle, quello sciocco, per riguardo a me come se a me potesse importare che t'abbia posseduta un uomo di meno, te... - e per la terza volta la disse quella parola. (...) / Ella ora, apparentemente estenuata, aveva paura; la faccia sbiancata, lo fissava con uno sguardo che chiedeva compassione. (...) Tutt'ad un tratto ella si svincolò e si mise a correre disperatamente. Ella dunque aveva mentito ancora! Egli non avrebbe saputo raggiungerla; si chinò, cercò un sasso, e non trovandone raccolse delle pietruzze che le scagliò dietro. II vento le portò e qualcuna dovette colpirla perché ella gettò un grido di spavento; altre furono arrestate dai rami secchi degli alberi e produssero un rumore sproporzionatissimo all'ira che aveva lanciate. In SVEVO, Italo. Romanzi e "continuazioni”. Milano: Mondadori, 2006, pp. 602-603.
} 
Angiolina é tachada de prostituta, característica que sela seu comportamento, sua índole, enfim seu destino. Seu comportamento inquieto e impulsivo quebra com o modelo de mulher recatada, obediente da época, que deveria sempre estar em segundo plano, ser uma sombra do homem. Angiolina busca seu lugar ao sol, quer brilhar, ser feliz e, ter os mesmos direitos dos homens. E isso seria mais um obstáculo para a concretização de sua relação com o inapto Emilio, que não consegue romper sua paralisia intelectual e agir de um modo diferente ao esperado da sociedade que representa. Ela, ao contrário, é pura ação, movimento e sua reflexão é pragmática. A bela é a encarnação da vitalidade, da saúde. Não apenas seus olhos crepitam, mas ela inteira.

A cena retrata ainda uma sociedade patriarcalista, que vê a infidelidade da moça como um crime, a ser punido. O comportamento de Emilio, ao abaixar-se e pegar um punhado de cascalho para atirar em Angiolina, remetenos à história bíblica da mulher adúltera, cuja condenação previa o apedrejamento. A alusão a tal história contribui para vitimizar ironicamente Emilio que fora objeto de uma mulher infiel e impura, que deve ser castigada brutalmente para que a honra do macho seja lavada.

Após o rompimento, Emilio parece ficar ainda mais perdido, sem saber o que fazer:

O que fazer agora? A última satisfação que anelara fora-lhe negada. Apesar de toda a sua resignação, tudo a seu redor permanecia rude, sem doçura; ele próprio fora brutal! As artérias batiam-lhe pela superexcitação; naquele frio ele ardia de ira, de febre, imóvel sobre as pernas paralíticas, e já renascia nele o observador calmo que o reprovara. 
- Não, nunca mais a vejo - disse como se respondesse a uma reprovação. - Nunca mais!

\section{$(\ldots)$}

Não foi logo para casa. Ter-lhe-ia sido impossível servir de enfermeiro nesse estado de espírito. Estava inteiramente possuído pelo sonho, tanto que não saberia depois dizer por que caminho regressara a casa. Oh! Se a entrevista com Angiolina tivesse sido tal como a quisera, teria podido seguir direto para junto do leito de Amalia sem a necessidade de alterar sequer a expressão da face. ${ }^{135}$ (SVEVO, 1982, pp.246 a 248, grifo nosso)

Após a fuga da moça, o caráter brutal de Emilio, animalesco, desaparece, renascendo nele, conforme palavras do narrador, "o observador calmo que o reprovara". O verdadeiro Emilio, "inteiramente possuído pelo sonho" fica desnorteado e não tem coragem de voltar para a casa e encarar uma outra realidade, a doença da irmã.

Terminar sua relação com Angiolina parece estar pautado por uma autopunição pelo estado da irmã e até por um falso moralismo que o impede de assumir Angiolina, a filha do povo, como sua mulher, uma vez que os amantes pertencem a classes sociais diferentes. Ainda que Emilio faça parte de uma classe social decadente, ele não poderia misturar-se a uma mulher de uma classe mais baixa que a sua. Aliado a isso, não se pode esquecer a inércia que toma conta de sua vida; Brentani não teria coragem nem forças para enfrentar

\footnotetext{
${ }^{135}$ Che cosa fare? L'ultima soddisfazione cui aveva anelato, gli era stata negata. Ad onta di tanta sua rassegnazione tutto intorno a lui rimaneva rude, sena dolcezza; egli stesso era brutale! Le arterie gli battevano dalla sovraeccitazione; in quel freddo egli ardeva d'ira, di febbre, immobile sulle gambe paralitiche e già era rinato in lui l'osservatore calmo che lo rimproverava. / - Non la rivedrò mai più - disse come per rispondere ad un rimprovero. Mai! Mai! (...) / Non andò subito a casa. Gli sarebbe stato impossibile d'atteggiarsi ad infermiere in quello stato d'animo. II sogno lo possedeva intero, tanto che non avrebbe saputo dire per quali vie fosse poi rincasato. Oh! Se l'abboccamento con Angiolina fosse stato quale egli l'aveva voluto, avrebbe potuto andare diritto al letto d'Amalia senz'alterare neppure l'espressione della propria faccia. Ibid., p.603.
} 
os valores da sociedade machista e moralista da qual ele faz parte. Assim só Ihe resta pagar pela morte da irmã, em vida. A solução para sua purgação é o afastamento físico da amante, bem como uma morte existencial que se concretizará em um aprisionamento nel mezzo del cammin de sua vida que se cristalizará na figura da senilidade:

Anos mais tarde olhava com certo encanto admirado para esse
período de sua vida, o mais importante, o mais luminoso. Vivia
como um velho com as recordações da juventude. Em seu
espírito de literato ocioso, Angiolina sofreu uma metamorfose
estranha. Conservou inalterada a beleza, mas adquiriu ainda
todas as qualidades de Amalia, que nela morreu uma segunda
vez. Tornou-se triste, desconsoladamente inerte, seu olhar
adquiriu uma limpidez intelectual. Via-a diante de si como sobre
um altar, a personificação do pensamento e da dor, e amou-a
sempre, se amor é admiração e desejo. (...) Sua figura, além do mais, tornou-se um símbolo. Olhava sempre o mesmo ponto do horizonte, o futuro do qual partiam os resplendores dourados que reverberavam em seu rosto róseo, luminoso e branco. Esperava! A imagem concretizava o sonho que ele uma vez erguera junto a Angiolina e que a filha do povo não soubera compreender. ${ }^{136}$ (SVEVO, 1982, pp.267268)

A única tentativa de Emilio entregar-se à vida e seus prazeres é frustrada. Seu lado literato, ficcional constrói mais uma vez subterfúgios que endossam uma realidade inexistente, que em nada se assemelha ao verdadeiro contexto que o cerca. Tudo em sua vida é "figural", criado

\footnotetext{
${ }^{136}$ Anni dopo egli s'incantò ad ammirare quel periodo della sua vita, il più importante, il più luminoso. Ne visse come un vecchio del ricordo della gioventù. Nella sua mente di letterato ozioso, Angiolina subì una metamorfosi strana. Conservò inalterata la sua bellezza, ma acquistò anche tutte le qualità d'Amalia che morì in lei una seconda volta. Divenne triste, sconsolatamente inerte, ed ebbe l'occhio limpido ed intelletuale. Egli la vide dinanzi a sé come su un altare, la personificazione del pensiero e del dolore e l'amò sempre, se amore è ammirazione e desiderio. (...) / Quella figura divenne persino un simbolo. Ella guardava sempre dalla stessa parte, l'orizzonte, l'avvenire da cui partivano i bagliori rossi che si riverberavano sulla sua faccia rosea, gialla e bianca. Ella aspettava! L'immagine concretava il sogno ch'egli una volta aveva fatto accanto ad Angiolina e che la figlia del popolo non aveva compreso. Ibid., pp. 620-621.
} 
artificialmente de modo a dificultar a identificação das mulheres como seres reais e complexos, que merecem um olhar liberto da transcendência lançada por ele.

Emilio, com exceção da cena da separação definitiva, ápice da história, será sempre o mesmo. Do início ao final da narrativa, Brentani não sofrerá nenhuma mudança, não conseguirá libertar-se de sua inaptidão e muito menos de seu caráter fantasioso e ficcional, que ainda buscará metamorfosear as duas mulheres de sua vida, a irmã com a qual ele fora negligente, e a amante, à qual ele tentara, inutilmente, transformar em um anjo inacessível, símbolo que coroa sua imaginação de literato senil.

Assim, Emilio Brentani constrói para sua opaca existência, a exemplo do defunto-autor Brás Cubas, de Machado de Assis, um capítulo só de negativas. Brentani comete uma espécie, se quisermos fazer uma comparação a Alfonso, de suicídio existencial, uma morte interior que o faz renunciar à vida e seus prazeres para entregar-se a uma eterna reclusão em sua precoce senilidade. 


\subsection{La coscienza di Zeno e o inapto às avessas}

La coscienza di Zeno, junto com os outros dois romances, forma uma trilogia, cujo objeto de análise, de acordo com Teresa de Lauretis, seria sempre o mesmo: "a condição humana, a relação entre o eu e o mundo, os modos, os porquês, os como da existência, as formas do universo da consciência"137 (LAURETIS, 1976, p.134, tradução nossa).

A conselho do psicanalista, no intuito de curar-se de sua hipotética "doença", Zeno começa a escrever sua história. De acordo com o suposto terapeuta, o misterioso Dr. S., esse processo seria importante para que Zeno pudesse se ver por inteiro. "Escreva! Escreva! O que acontecerá, então, é que você vai se ver por inteiro"138 (SVEVO, 2006, p.15), aconselha o misterioso Dr. S..

Franco Moretti salienta que a figura do Doutor S. corrobora com mais indagações acerca do protagonista, suscitando perguntas como, "Qual ‘verdade' Zeno irá narrar?", "A que convença ao médico, tendo para si uma outra?", "Ou a 'verdade' que o traduz?". Essa impossibilidade de respostas, que esclareçam tais questões, é vista por Moretti como algo suspeito (MORETTI, 1950, p. 393). O comportamento de Zeno em si parece "suspeito", consequentemente, não podemos acreditar que encontraremos no relato uma verdade absoluta. Diante disso, preferimos falar em hipóteses e não em

\footnotetext{
${ }^{137}$ la condizione umana, il rapporto tra io e mondo, le modalità, i perché, i come dell'esistenza, le forme dell'universo della coscienza. In LAURETIS, Teresa de. La sintassi del desiderio: Struttura e forme del romanzo sveviano. Ravenna : Longo Editore, 1976, p.134.

138 - Scriva! Scriva! Vedrà come arriverà a vedersi intero. In SVEVO, Italo. Romanzi e “continuazioni". Milano: Mondadori, 2006, p.628.
} 
"verdades" ou afirmações categóricas, uma vez que a narrativa é construída pelo autor alicerçada na ambiguidade.

Com exceção do último capítulo, "Psicanálise", escrito em forma de diário, há no romance a predominância da forma narrativa autobiográfica, ou pseudo-autobiográfica, já que o sujeito que a enuncia está ligado ao mundo ficcional.

O termo pseudo-autobiografia parece ser o mais indicado, uma vez que evidencia que a autobiografia é do narrador, Zeno, e não do escritor, Italo Svevo. Tal pontuação justifica-se pelo fato do grande questionamento, por parte de uma parcela da crítica italiana, quanto à história contada por Zeno tratar-se, na verdade, da própria vida de Svevo. A esse propósito, o escritor tomou uma postura digna de sua grandiosidade como literato. Em uma carta ao amigo Eugenio Montale, Svevo magistralmente joga por terra a suposição de que a autobiografia seria dele e não do personagem ficcional Zeno Cosini:

\begin{abstract}
É verdade que a Coscienza é bem diferente dos romances anteriores. Pense que seja uma autobiografia, não a minha. Muito menos de Senilità. Empreguei três anos para escrevê-lo nos meus retalhos de tempo. E procedi assim: quando estava sozinho procurava convencer-me de que eu era o próprio Zeno. Caminhava como ele, como ele fumava, e jogava no meu passado todas as suas aventuras que pudessem assemelharse às minhas, isso porque a reevocação de uma verdadeira aventura é uma reconstrução que facilmente torna-se uma construção totalmente nova, quando se consegue colocá-la em uma atmosfera diversa. E não perde por isso o sabor e o valor da lembrança, e muito menos a sua tristeza. Estou certo que o senhor me entende ${ }^{139}$. (TEDESCO, 1999, p.135, tradução nossa)
\end{abstract}

\footnotetext{
139 È vero che la Coscienza è tutt'altra cosa dei romanzi precedenti. Ma pensi ch'è un'autobiografia e non la mia. Molto meno di Senilità. Ci misi tre anni a scriverlo nei miei ritagli di tempo. E procedetti così: quand'ero lasciato solo cercavo di convincermi d'essere io stesso Zeno. Camminavo come lui, come lui fumavo, e cacciavo nel mio passato tutte le sue avventure
} 
De acordo com Mario Lavagetto, Svevo resolveu esse "problema" com a invenção de um gênero impossível: uma autobiografia de outrem (LAVAGETTO, 2004, pp.LXV-LXVI).

Ao discorrer sobre a forma narrativa autobiográfica, Jean Pouillon, ressalta que o indivíduo, ao escrever suas memórias, procura entender a razão por ter feito isto ou aquilo, sendo que, nessa empreitada, não é preciso que ele seja sincero, mas lúcido. A reconstituição de um passado só é significativa e possível, ainda de acordo com Pouillon, graças ao que ele chama de “imaginação compreensiva” (POUILLON, 1974, p.40).

Dessa forma entramos em contato com as verdades e mentiras do protagonista, que diferentemente de seus "irmãos mais novos", Alfonso e Emilio, apresenta-se imerso e "adaptado" à sociedade em que vive. Se Alfonso busca integrar-se, sem sucesso, à sociedade e Emílio esteja integrado a ela, de forma decadente e marginal, Zeno incorporará e saberá tirar proveito de sua condição de burguês abastado, que sequer precisará trabalhar para ganhar o pão de cada dia. O próprio pai parece não acreditar na capacidade do filho e ainda em vida deixa registrado em testamento que o velho Olivi, administrador dos negócios da família, continuará a gerenciar os bens dos Cosini. De acordo com Elio Gioanola o caráter inapto de Zeno já é destacado pelo pai, que o acha incapaz de administrar o patrimônio familiar (GIOANOLA, 1995, p.51), privando-o de tal função:

che possono somigliare alle mie solo perché la rievocazione di una propria avventura è una ricostruzione che facilmente diventa una costruzione nuova del tutto quando si riesce a porla in un'atmosfera nuova. E non perde perciò il sapore e il valore del ricordo, e neppure la sua mestizia. Io sono sicuro che Lei m'intende. In TEDESCO, Natale. La coscienza letteraria del novecento : Gozzano, Svevo ed altri esemplari. Palermo : Flaccovio Editore, 1999, p.135. 
- Quero dizer-Ihe que fiz meu testamento.

Eu, para afastá-lo do seu íncubo, refiz-me logo da surpresa que sua comunicação produzira e retruquei:

- Eu não me darei a esse trabalho, pois espero que meus herdeiros morram antes de mim!

Ele inquietou-se por eu rir de um assunto tão sério e reavivou seu velho desejo de punir-me. Foi-lhe assim fácil contar-me que bela peça me pregava colocando-me sob a tutela de Olivi.

- Talvez - acrescentei - saiba comportar-me de maneira a que o senhor se veja inclinado a modificar suas disposições.

Isso Ihe agradou bastante, inclusive porque notava que eu the atribuía uma longa vida, a bem dizer longuíssima. Contudo, quis de mim o juramento imediato de que, se ele viesse a dispor de outra forma, eu não iria interferir nas atribuições de Olivi. Tive que jurar, já que não se contentava com minha palavra de honra. ${ }^{140}$ (SVEVO, 2006, p.44, grifo nosso)

Os termos em destaque demonstram que o patriarca da família Cosini não acredita nem confia na capacidade do filho em gerenciar os bens da família. Temeroso de que o patrimônio familiar seja gerido pelo filho, o pai, ainda vivo, faz questão de registrar em um documento legal, um testamento, o seu desejo, que aponta, como bem ressaltou Elio Gioanola, o caráter inapto de Zeno.

\footnotetext{
${ }^{140}$ - Devo dirti che ho fato testamento. / lo, per stornarlo dal suo incubo, vinsi subito la sorpresa che mi produsse la sua comunicazione e gli disse: - lo non avrò mai questo disturbo perché spero che prima di me muoiano tutti i miei eredi! / Egli subito si inquietò del mio riso su una cosa tanto seria e ritrovò tutto il suo desiderio di punirmi. Così gli fu facile di raccontarmi il bel tiro che m'aveva fatto mettendomi sotto la tutela dell'Olivi. / (...) - Forse - aggiunsi - io saprò comportarmi in modo che tu ti troverai indotto a cambiare le tue ultime volontà. / Ciò gli piacque anche perché vedeva ch'io gli attribuivo una vita lunga, anzi lunghissima. Tuttavia volle da me addirittura un giuramento, che se egli non avesse disposto altrimenti, io non avrei mai tentato di sminuire le facoltà dell'Olivi. lo giurai visto ch'egli non volle contentarsi della mia parola d'onore. In SVEVO, Italo. Romanzi e "continuazioni”. Milano: Mondadori, 2006, pp. 658-659.
} 
Nos romances anteriores, a causa principal da inaptidão dos protagonistas concentrava-se na incapacidade desses reconhecerem-se como "produtos" da sociedade da qual fazem parte. Alfonso Nitti a renegara drasticamente com o suicídio; Emilio Brentani com o refúgio em sua solitária senilidade existencial; Zeno, mais maduro e mais rico, pode observar o mundo de um ponto de vista privilegiado, e consequentemente encarar suas limitações e reconhecer-se doente, em uma sociedade nada sadia. Contudo, a postura do senhor Cosini permite-Ihe viver a vida de maneira mais leve e plena. Uma vida que já não é mais madrasta, "não é boa nem má; é original" (SVEVO, 2006, p.322). Zeno desde jovem reconhece sua origem burguesa:

No espírito de um jovem de origem burguesa o conceito de vida humana associa-se ao da carreira e, na mocidade, o que se entende por carreira é a de Napoleão. Não que necessariamente 0 jovem sonhe em tornar-se imperador, já que é possível assemelhar-se a Napoleão permanecendo em escala muito inferior. A vida mais intensa pode ser sintetizada pelo mais rudimentar dos sons, o da onda do mar, que, a partir do momento em que se forma, muda sem cessar até o instante em que morre! Eu também aspirava a transformar-me e desfazer-me, a exemplo de Napoleão e da onda. ${ }^{141}$ (SVEVO, 2006, p.67, grifo nosso)

Zeno Cosini aceita-se como parte da sociedade, e de certo modo, mergulha na sua existência, que a exemplo da onda do mar, nunca será a mesma. Cosini parece ter entendido que não pode remar contra a maré, o que se pode fazer é aceitar a originalidade da vida. De acordo com Nicoletta Donati:

\footnotetext{
${ }^{141}$ Nella mente di un giovine di famiglia borghese il concetto di vita umana s'associa a quello della carriera e nella prima gioventù la carriera è quella di Napoleone I. Senza che perciò si sogni di diventare imperatore perché si può somigliare a Napoleone restando molto ma molto più in basso. La vita più intensa è raccontata in sintesi dal suono più rudimentale, quello dell'onda del mare, che, dacché si forma, muta ad ogni istante finché non muore! M'aspettavo perciò anch'io di divenire e disfarmi come Napoleone e l'onda. Ibid., p. 685.
} 
Zeno Cosini não acredita em nada, não tem valores para afirmar, pois compreendeu que nada faz sentido, é um "homem onda" que se deixa deslocar com total descompromisso; atingiu (à diferença dos outros protagonistas) a consciência de que na existência "a originalidade da vida", isto é, a sua constante problemática, deve-se à sua substancial imprevisibilidade e, portanto, à sua falta de propósito, à sua realidade doente. ${ }^{142}$ (DONATI, 2000, p.57, tradução nossa)

A definição "homem onda", proposta por Donati, cabe perfeitamente a Zeno, que ao invés de contestar as querelas da vida, deixa-se conduzir-se pelo improviso, aceitando sua realidade "doente". Ele não só tem consciência da doença do homem moderno como sabe que não existe a cura para a mesma:

Naturalmente não sou ingênuo e desculpo o doutor que vê na própria vida uma manifestação da doença. A vida assemelhase um pouco à enfermidade, à medida que procede por crises e deslizes e tem seus altos e baixos cotidianos. À diferença das outras moléstias, a vida é sempre mortal. Não admite tratamento. Seria como tapar os orifícios que temos no corpo, imaginando que sejam feridas. No fim da cura estaríamos sufocados. ${ }^{143}$ (SVEVO, 2006, p.420)

Se para o enigmático Doutor S. a vida é manifestação de doença, para

Zeno, ainda que o conceito de vida esteja atrelado à determinada enfermidade, a doença indica a descoberta de si próprio e da realidade que o circunda. Não existem pessoas sãs, todos são "doentes" e a verdadeira cura "não admite

${ }^{142}$ Zeno Cosini non crede in nulla, non ha valori da affermare perché ha capito che niente ha senso, è un "uomo onda" che si lascia trasportare con totale disimpegno; ha raggiunto (a differenza degli altri protagonisti) la consapevolezza che nell'esistenza "l'originalità della vita", cioè la sua costante problematicità, è dovuta alla sua sostanziale imprevedibilità e quindi alla sua mancanza di scopo, alla sua realtà di malattia. In DONATI, Nicoletta. Svevo: crisi del soggetto ed estetica della crisi. Perugia, 1999/2000. Laurea in Filosofia. Università degli Studi di Perugia - Facoltà di Lettere e Filosofia, p.57.

${ }^{143}$ Naturalmente io non sono un ingênuo e scuso il dottore di vedere nella vita stessa una manifestazione di malattia. La vita somiglia un poco alla malattia come procede per crisi e lisi ed ha i giornalieri miglioramenti e peggioramenti. A differenza delle altre malattie la vita è sempre mortale. Non sopporta cure. Sarebbe come voler turare i buchi che abbiamo nel corpo credendoli delle ferite. Morremmo strangolati non appena curati. In SVEVO, Italo. Romanzi e "continuazioni". Milano: Mondadori, 2006, pp. 1083-1084. 
tratamento, pois no fim da cura estaríamos sufocados". Diante disso, só resta conformar-se de que a doença está enraizada desde origens do homem:

A vida atual está contaminada até as raízes. $O$ homem usurpou o lugar das árvores e dos animais, contaminou o ar, limitou o espaço livre. Mas o pior está por vir. O triste e ativo animal pode descobrir e pôr a seu serviço outras forças da natureza. Paira no ar uma ameaça deste gênero. Prevê-se uma grande riqueza...no número de homens. Cada metro quadrado será ocupado por ele. Quem se livrará da falta de ar e de espaço? Sufoco só de pensar nisto!

E infelizmente não é tudo.

Qualquer esforço de restabelecer a saúde será vão. Esta só poderá pertencer ao animal que conhece apenas o progresso de seu próprio organismo. Desde o momento em que a andorinha compreendeu que para ela não havia outra vida possível senão emigrando, o músculo que move as suas asas engrossou-se, tornando-se a parte mais considerável de seu corpo. A toupeira enterrou-se e todo o seu organismo se conformou a essa necessidade. O cavalo avolumou-se e seus pés se transformaram em cascos. Desconhecemos as transformações por que passaram alguns outros animais, mas elas certamente existiram e nunca lhes puseram em risco a saúde. ${ }^{144}$ (SVEVO, 2006, p.421, grifo nosso)

É evidente nessa passagem a influência da teoria evolucionista de

Darwin, biólogo naturalista lido por Svevo. Os animais souberam se adaptar à selva, à lei do mais forte, desenvolvendo mecanismos de defesa. O homem, em contrapartida, já nascera doente, não soubera evoluir a exemplo dos

\footnotetext{
${ }^{144}$ La vita attuale è inquinata alle radici. L'uomo s'è messo al posto degli alberi e delle bestie ed ha inquinata l'aria, ha impedito il libero spazio. Può avvenire di peggio. II triste e attivo animale potrebbe scoprire e mettere al proprio servizio delle altre forze. V'è una minaccia di questo genere in aria. Ne seguirà una grande ricchezza... nel numero degli uomini. Ogni metro quadrato sarà occupato da un uomo. Chi ci guarirà della mancanza di aria e di spazio? Solamente al pensarci soffoco! / Ma non è questo, non è questo soltanto. / Qualunque sforzo di darci la salute è vano. Questo non può appartenere che alla bestia che conosce un solo progresso, quello del proprio organismo. Allorché la rondinella comprese che per essa non c'era altra possibile vita fuori dell'imigrazione, essa ingrossò il muscolo che muove le sue ali e che divenne la parte più considerevole del suo organismo. La talpa s'interrò e tutto il suo corpo si conformò al suo bisogno. II cavallo s'ingrandì e trasformò il suo piede. Di alcuni animali non sappiamo il progresso, ma ci sarà stato e non avrà mai leso la loro salute. Ibid., p. 1084.
} 
animais e a vida a "cada minuto que passa, lança-Ihe um reagente. Há demasiadas possibilidades de doenças para ti, porque não é possível que sejam puros todos esses minutos"145 (SVEVO, 2006, p.14).

Diante disso "qualquer esforço de restabelecer a saúde será vão". A solução estaria em "uma catástrofe inaudita, provocada pelos artefatos"; uma explosão enorme que causasse o retorno da Terra "à sua forma original de nebulosa, (...) livre dos parasitos e das enfermidades"146 (SVEVO, 2006, pp.421-422). Só assim o homem poderá retornar a seu estado são.

O tema da inaptidão do sujeito, como podemos perceber, é representado neste romance de forma mais fluida, mais natural e universal que condena 0 homem à extinção. Essa fluidez segue a consciência de nosso narrador, por um viés mais irônico e ácido e intrinsecamente ligado à doença, tema recorrente na narrativa sveviana. Ainda que Zeno demonstre maior aderência ao meio em que vive, o vício do fumo pode ser analisado como a incapacidade do protagonista em não aceitar e não conseguir incorporar determinados valores dessa sociedade.

Zeno, sem dúvida, diferentemente dos outros protagonistas, consegue tirar proveito de várias situações, o que Ihe propicia desfrutar de uma vida mais satisfatória. Ainda que bem sucedido, Zeno é um inapto, que não consegue integrar-se de modo pleno na sociedade burguesa, da qual ele é fruto. Através

\footnotetext{
${ }^{145}$ (...) Ogni minuto che passa vi getta un reagente. Troppe probabilità di malattia vi sono per te, perché non tutti i tuoi minuti possono essere puri. Ibid., p. 627.

${ }^{146}$ una catastrofe inaudita prodotta dagli ordigni (...) e la terra ritornata alla forma di nebulosa ... priva di parassiti e di malattie. Ibid., p. 1085.
} 
de seu discurso irônico, burlesco existe uma grande crítica a essa sociedade corrompida, doente e sem esperança de cura. A única saída é a extinção total dessa humanidade apática, dando espaço ao nascimento de uma outra sociedade, "livre dos parasitos e enfermidades". 


\section{Considerações Finais}

Do itinerário inicial traçado para orientar nossos percursos, chegamos à tessitura das possíveis considerações finais. Nossa primeira hipótese de pesquisa foi a análise do ambiente triestino e suas correlações com a narrativa sveviana. Pudemos perceber a forte presença da cidade na narrativa dos romances e nas histórias dos personagens. Assim, como há uma Paris, imortalizada por Zola, há uma Trieste de Svevo que, com sua obra, nos convida a ceder a suas belezas e particularidades.

A cidade constituiu, como bem notou Lunetta, uma espécie de palco onde "conviveram" grandes confluências étnicas, linguísticas, culturais que se misturavam, fundindo-se, muitas vezes. Essa "caldeira" de raças e civilizações contribuiu na formação e composição dessa cidade "dialógica" (LUNETTA, 1976, p.18).

Ao explorar o ambiente triestino foi possível, primeiramente, situar o leitor acerca dessa cidade italiana limítrofe e mitteleuropea, que sofreu forte influência da cultura alemã, mas que conseguiu inserir-se no cenário europeu como uma importante cidade portuária. Além disso, a revisitação aos ambientes e à sociedade, particularmente burguesa, descrita nos romances, foi fundamental para mostrar que Svevo constrói uma narrativa na qual seu personagem encontra-se à margem do espaço habitado. Existe uma cisão entre o mundo e o sujeito, que não consegue se reconhecer como parte desse ambiente.

Diante disso, chegamos à inferência de que entre o ambiente social triestino, tipicamente burguês, e os personagens, em especial os protagonistas, 
há um conflito, que termina por criar uma relação desarmônica entre ambos. Tal dissonância entre o eu e o seu mundo, evidenciou que o ambiente, nos romances analisados, pode se tornar hostil aos desejos e anseios dos protagonistas. Desse modo, o espaço social atua como um mecanismo a gerar medo nesses personagens, que encurralados em algumas situações, entrarão em contato com seus sentimentos de insegurança e inferioridade, característicos de seus caráteres inaptos. Inseguros e se sentindo ainda mais inferiores, eles tendem a buscar "amparo" em outros personagens, demonstrando uma forte tendência à possessão, que se cristaliza no ciúme que perpassa suas histórias.

Assim, o enveredamento pelo ambiente triestino levou-nos a um prognóstico de que o ciúme retratado na narrativa sveviana está fortemente ligado à insegurança, da qual esses personagens inaptos são vítimas. O ciumento, como bem notou Bordelois, "teme ser despojado daquilo que acredita possuir" (BORDELOIS, 2007, p.119). Tal sentimento de medo, que gera o ciúme ressaltado pela crítica, encontra na insegurança uma de suas razões para existir.

Em Una Vita, pudemos comprovar que há maior destaque para a caracterização dos ambientes internos. Toda história se concentra no banco, na casa do senhor Maller, dono da instituição financeira, e no quarto alugado pelo protagonista, na casa da decadente família Lanucci. Os ambientes exteriores surgem como verdadeiras conexões para esses ambientes internos.

Em contrapartida, em Senilità, a caracterização do ambiente triestino concentra-se, sobretudo, nos ambientes exteriores. Assim, o leitor poderá 
vivenciar juntamente com Emilio Brentani e Angiolina Zarri, uma frequente movimentação pelos mais belos e fascinantes lugares exteriores, dessa Trieste um pouco mais sentimental e romântica, já que a instância narrada passa pelo filtro emocional e ficcional do protagonista, Emilio Brentani. A cidade neste romance será não apenas o cenário da relação conturbada de Brentani e Zarri, mas também uma espécie de confidente dessa paixão, marcada pela fuga de Emilio do mundo real. Ele constantemente se servirá de mecanismos para idealizar tal relação com sua amante, expondo-se a frequentes crises de ciúme.

Se em Una vita e Senilità, a Trieste foi apresentada, respectivamente, a partir do viés do subalterno, em La coscienza di Zeno, somos convidados a conhecer o ambiente triestino pelo olhar do burguês, rico, maduro e ocioso Zeno Cosini. A Trieste retratada aqui é, sobretudo, o espaço da burguesia capitalista e consumista, cujo símbolo máximo é o Tergesteo (Bolsa de Valores de Trieste), definido por Marani (2003), como o templo dos negócios.

Além da Trieste ligada às atividades econômicas e financeiras, que retratam uma próspera época da cidade, pudemos apreender um ambiente familiar tipicamente burguês, representado, sobretudo pela casa de Zeno, após seu matrimônio com Augusta Malfenti.

Após o estudo do ambiente triestino na narrativa sveviana, dedicamonos a entender o ciúme, a partir de algumas teorias de diferentes correntes ideológicas, no entanto encontramos um ponto comum entre elas: a triplicidade desse sentimento, que sempre envolverá o eu ciumento, o objeto de desejo e o outro, que chamamos de rival ou mediador, conforme a teoria de Girard (2009), adotada para fundamentar a análise do ciúme nos três romances. 
Ainda conforme postulado de Girard, pudemos notar que há predominância da chamada mediação interna nos romances, ou seja, quando existe contato entre sujeito-desejante e seu rival ou mediador. O outro tipo de mediação, a externa, em que não há uma relação próxima entre sujeitodesejante e rival, também foi encontrada, ainda que em menor número nas narrativas, todavia optamos por evidenciá-las através de exemplos ao longo desse capítulo.

Pudemos verificar também que Italo Svevo, como bem destacou Broccoli, segue, etapa por etapa, o caminho do homem da juventude à velhice (BROCCOLI,1972, p.40). Alfonso Nitti, protagonista do romance de estreia do escritor triestino, Una Vita, tem apenas 22 anos, encontra-se em plena juventude. Emilio Brentani, protagonista de Senilità, tem 35 anos, está nel mezzo del cammin, entre uma juventude madura e uma velhice precoce. Já, Zeno Cosini, protagonista de La coscienza di Zeno, com seus 57 anos representa a velhice. Assim, o escritor acompanha o processo evolutivo natural da vida através desses protagonistas, o que nos permitiu traçar diferenças e semelhanças entre as narrativas, em especial, no que diz respeito ao caráter inapto, inseguro, possessivo e consequentemente ciumento de tais personagens.

Em Alfonso Nitti pudemos ver características intempestivas próprias da juventude, como a resistência em não abandonar sua zona de segurança na casa da mãe e o seu "enamoramento" pela jovem e rica Annetta Maller, que apresenta momentos de puro sentimentalismo e possessão típicos de um adolescente, além de ser uma marca da inaptidão de Alfonso. Depois do 
protagonista despertar interesse por seu objeto de desejo, sua relação com a jovem será sempre triangular, haverá sempre um rival, superior fisicamente a duelar com ele pelo interesse da moça. O ciúme e a insegurança só terão fim com o suicídio de Alfonso, que reitera sua incapacidade de integrar-se ao ambiente da sociedade burguesa e capitalista da época. Assim, Nitti renúncia à vida e aos seus desafios, mas também aos seus prazeres.

Emilio Brentani, que se encontra na vida adulta, ao se apaixonar perdidamente pela "filha do povo", Angiolina Zarri, parece viver uma eterna adolescência, no sentido biológico de puberdade, ou seja, como bem ressaltou Teresa de Lauretis, período que prevê a completa maturidade sexual e social (LAURETIS, 1976, p.62). No entanto, Emilio, embora seja um adulto, não conseguirá conquistar essa maturidade sexual e afetiva, uma vez que não saberá lidar com sua "aventura amorosa", por criar uma mulher irreal, que existe apenas em seu mundo ficcional, e ao entregar-se às suas crises de ciúme, que reiteram seu caráter inapto e inseguro, completamente à mercê da amante astuta. A história de Emílio também será marcada por relações triangulares, rivais mais fortes e superiores, traições, bem como, pelo seu refúgio no mundo ficcional que o aprisionará em uma perene senilidade existencial.

Zeno Cosini, aos 57 anos, mais maduro e, amparado por sua classe social abastada, conseguirá lidar de forma diferente com o ciúme. Ainda que ele se sinta velho e doente, e essa doença possa ser vista como sua incapacidade de integração total ao seu mundo, sua maturidade e sua posição 
social burguesa permitem que ele consiga tirar proveito de situações diversas e aproveitar melhor os prazeres da vida.

Zeno também será alvo do ciúme, sua história será permeada por triângulos amorosos e rivais, todavia, sua postura e também o olhar distanciado dos acontecimentos, uma vez que Zeno narrador "reinvoca", analisa e comenta aquilo que Zeno personagem viveu, imprimem ao vivido um tom mais ameno e, em alguns casos, burlesco (CLAAR, 1986, p.74). Desse modo Zeno, como já foi dito, concretiza com a amante Carla Gerco, o que Emilio pretendia com Angiolina Zarri, uma aventura casual.

Da análise sobre a problemática em torno da presença do ciúme na narrativa sveviana, fomos conduzidos a revisitar um dos temas mais recorrentes da obra de Italo Svevo, a inaptidão do sujeito. O personagem "vencido", característico da sociedade burguesa, retratado por Svevo, diante do "mundo novo", representado pelo avanço gritante do sistema capitalista, não consegue integrar-se a essa nova realidade e se sente à margem. Tal inapto é o herói problemático, figura típica do romance moderno, cuja interioridade, de acordo com Lukács "nasce da dualidade antagônica entre alma e mundo" (LUKÁCS, 2002, p.90).

Os três protagonistas dos romances são inaptos, mas, como procuramos evidenciar, existem alguns particulares desse caráter inapto em cada um deles. Alfonso Nitti é o inapto que renúncia a uma sociedade que o exclui, assim seu suicídio além de evidenciar sua incapacidade em viver nesse ambiente hostilizante, pode ser visto como um ato de libertação. Emilio Brentani, ainda que se encontre inserido nessa sociedade, sente-se marginalizado e não 
consegue integrar-se à mesma; sua senilidade existencial, seu "suicídio em vida" também é uma forma de negação da vida e de renúncia a viver nessa sociedade indiferente e hostil. Zeno Cosini, o último inapto analisado, encontra certas dificuldades para inserir-se totalmente em seu meio, contudo à diferença dos outros protagonistas, aceita sua "doença" e, privilegiado, principalmente pela condição social, relaciona-se melhor com sua inaptidão e não pretende renunciar à vida, mas gozá-la, pois tem consciência de que a humanidade é doente, e de que não há salvação a não ser começar do zero.

Italo Svevo, desse modo, concebe sua arte como uma espécie de "remédio" para um sujeito que não consegue se identificar plenamente com o ambiente em que está inserido. Sua narrativa se constitui em um emaranhado de fios que se cruzam: o ambiente triestino e a relação com suas obras, a problemática do ciúme, e a figura do inapto, constituem-se em temas, ou melhor, em fios, que se interseccionam e "dialogam" entre si. Desse modo, concluímos que nossas hipóteses de trabalho não se excluem, mas se complementam. O sujeito idealizado por Svevo não existiria sem seu ambiente burguês, frio, indiferente e, por vezes, hostil. Da mesma forma, perderia sua identidade sem seu caráter inapto, inseguro e ciumento. Assim, ambiente social, ciúme e inaptidão formam uma tríade essencial para a composição triangular da narrativa sveviana que enriqueceu o romance italiano do início do século $\mathrm{XX}$, conquistando seu lugar de clássico da literatura moderna não só italiana, mas mundial. 


\section{Referências bilbiográficas}

I - Obras de Italo Svevo

SVEVO, Italo. Uma vida; tradução e notas de Aurora Fornoni Bernardini e Homero Freitas de Andrade. São Paulo: Nova Alexandria, 1993.

Senilidade; tradução de Ivo Barroso. Rio de Janeiro: Nova Fronteira, 1982.

A consciência de Zeno; tradução de Ivo Barroso. Rio de Janeiro: Nova Fronteira, 2006.

Romanzi e "continuazioni”. Milano: Mondadori, 2006.

II - Obras sobre Italo Svevo

ABRUZZESE, Alberto. Svevo, Slataper, Michelstaedter: lo stile e il viaggio. Venezia: Marsilio Editori, 1979.

ANZELLOTTI, Fulvio. II segreto di Svevo. Pordenone: Edizioni Studio Tesi, 1985.

APIH, Elio. La società triestina negli anni di Svevo. In PETRONIO, Giuseppe. II caso Svevo. Palermo: Palumbo, 1988, pp. 9-36.

BON, A. Come leggere "La coscienza di Zeno" di Italo Svevo. Milano: Mursia, 1977. 
BORGHELLO, Giampaolo. La coscienza borghese: saggio sulla narrativa di Svevo. Roma: Savelli, 1977.

BROCCOLI, Maria Gabriella Tuzio. Italo Svevo e la problematica del novecento. Casa Editrice Beneventana: Benevento, 1972.

CACCIAGLIA, Norberto. Senilità um romanzo indiziario. In: CACCIAGLIA, N. e GUZZETTA, L.F. (cura di) Italo Svevo scrittore europeo. Firenze: Leo S. Olschki Editore, 1992, pp. $301-324$.

CAMERINO, Giuseppe Antonio. Italo Svevo e la crisi della mitteleuropa. Firenze: Casa Editrice Le Monnier, 1974.

CASTRO, Silvio. Svevo, da incompreensão à consagração. O Estado de São Paulo, 15-09-1985, p.8.

CLAAR, Micaela Pretolani. Guida alla lettura di Svevo. Milano: Mondadori, 1986.

DEL MISSIER, S. Italo Svevo. Firenze: Le Monnier, 1987.

DONATI, Nicoletta. Svevo: crisi del soggetto ed estetica della crisi. Perugia, 1999/2000. Laurea in Filosofia. Università degli Studi di Perugia Facoltà di Lettere e Filosofia.

FUSCO, M. Italo Svevo. Palermo: Sellerio Editore, 1984.

GHIDETTI, Enrico. Italo Svevo: la coscienza di un borghese triestino. Roma: Editori Riuniti, 1992.

GIOANOLA, Elio. Un killer dolcissimo: indagine psicanalitica sull'opera di 
Italo Svevo. Milano: Mursia, 1995.

LAURETIS, Teresa de. La sintassi del desiderio: Struttura e forme del romanzo sveviano. Ravenna : Longo Editore, 1976.

LAVAGETTO, Mario. L'impiegato Schmitz e altri saggi su Svevo. Einaudi: Torino, 1986.

. II romanzo oltre la fine del mondo. In Romanzi e “continuazioni”. Milano: Mondadori, 2006.

LUNETTA, Mario. Invito alla lettura di Svevo. Torino : Mursia, 1976.

MAGRIS, Claudio. Svevo e la cultura tedesca a Trieste. In PETRONIO, Giuseppe. II caso Svevo. Palermo: Palumbo, 1988, pp.37-56.

MAIER, B. Italo Svevo. Milano: Mursia, 1980.

MANACORDA, Giuliano. Italo Svevo. In MANACORDA, Giuliano. Vent'annni di pazienza - saggi sulla letteratura italiana contemporanea. Firenze: La Nuova Italia, 1972, Serie Biblioteca di Cultura, pp. 161-187.

MARANI, Diego. A Trieste con Svevo. Milano: Bompiani, 2003.

MICELI-JEFFRIES, Giovanna. Per una poetica della senilità: la funzione della donna in Senilità e Un amore. Italica, Vol. 67, №. 3, 1990, pp. 353-370. Disponível em: <http://www.jstor.org/stable/478643>. Acesso em 25 maio 2014.

MOLONEY, Brian. Italo Svevo narratore: lezione triestine. Gorizia: Libreria Editrice Goriziana, 1998. 
MONTALE, Eugenio. Omaggio a Italo Svevo. L'esame (Rivista mensile di coltura e d'arte). Anno IV. Fascicolo XI-XII - Novembre-Dicembre, 1925, pp. 804-813.

PALUMBO, Matteo. II romanzo italiano da Foscolo a Svevo. Roma: Carocci, 2007.

PELLEGRINI, Ernestina. Se un bruciatore di streghe revivesse, avrebbe rimorso? In RUGLIANO, Anna Rosa et all. Rincorrendo Angiolina....figure femminile nella vita e letteratura sveviana. Trieste: Museo Sveviano, 1999, pp.9-28

SPAGNOLETTI, Giacinto. Svevo: da "Una vita" a "La coscienza di Zeno". Modena: Mucchi editore, 1991.

STASI, Beatrice. Svevo. Bologna: Mulino, 2009.

SVEVO, Livia Veneziani. Vita di mio marito. Dall'Oglio Editore: Milano, 1976.

TEDESCO, Natale. La coscienza letteraria del novecento : Gozzano, Svevo ed altri esemplari. Palermo : Flaccovio Editore, 1999.

VERBARO, Caterina. Italo Svevo. Soveria Mannelli/Calabria: Rubbettino, 1997.

VICENTINI, Marzia Terenzi. Encontro com Svevo. São Paulo: 1984. Tese de Doutoramento (Área de Teoria Literária e Literatura Comparada). Faculdade de Filosofia, Letras e Ciências Humanas da Universidade de São Paulo. 
III - Obras de Referência

ANDRADE, Gabriel. René Girard: um retrato intelectual. Tradução Carlos Nougué. São Paulo: É Realizações Editora, 2011.

BAKHTIN, Mikhail. Questões de literatura e de estética: a teoria do romance. São Paulo: Annablume Editora; Hucitec, 2002, $5^{\mathrm{a}}$ ed.

BARTHES, Roland. Fragmentos de um discurso amoroso; tradução Hortênsia dos Santos. Rio de Janeiro: F. Alves, 1981.

BENVENUTO, Sergio. La gelosia. Bologna: Mulino, 2011.

BORDELOIS, Ivonne. Etimologia das paixões; tradução Luciano. Rio de Janeiro: Odisséia Editorial, 2007.

BROMBERT, Victor. Em louvor de anti-heróis: figuras e temas da moderna literatura européia; tradução José Laurenio de Melo. São Paulo: Ateliê Editorial, 2001.

COLI, Jorge. O lenço e o caos. In: Os sentidos da paixão. NOVAES, Adauto (org.). São Paulo: Companhia das Letras, 2009.

DEBENEDETTI, Giacomo. Italiani del novecento. Firenze: Giunti, 1995.

. II romanzo del novecento. Milano: Garzanti, 1987.

FREUD, Sigmund. Alguns mecanismos neuróticos no ciúme, na paranóia e no homossexualismo. In FREUD, Sigmund. Além do princípio de prazer psicologia de grupo e outros trabalhos. Tradução Christiano Monteiro 
Oiticica. Rio de Janeiro: Imago Editora, s/d.

GIRARD, René. A crítica no subsolo; tradução Martha Gambini. Rio de Janeiro: Paz e Terra, 2011.

Geometrie del desiderio. Milano: Raffaello Cortina Editore, 2012.

Mentira romântica e verdade romanesca; tradução Lilia Ledon da Silva. São Paulo: É Realizações, 2009.

. Struttura e personaggi nel romanzo moderno. Milano: Bompiani, 1965.

. Um longo argumento do princípio ao fim: diálogos com

João Cezar de Castro Rocha e Pierpaolo Antonello; tradução Bluma Waddington Vilar. Rio de Janeiro: Topbooks, 2000.

GREIMAS, Algirdas Julien. FONTANILLE, Jacques. Semiótica das paixões: dos estados das coisas aos estados de alma; tradução Maria José Rodrigues Coracini. São Paulo: Editora Ática, 1993.

GRIMALDI, Nicolas. O ciúme: estudo sobre o imaginário proustiano; tradução Antonio de Padua Danesi. Rio de Janeiro: Editora Paz e Terra, 1994.

GROSSER, Hermann. Narrativa. Milano: Casa Editrice G. Principiato, 1986.

KLEIN, Melanie. Inveja e gratidão. In: Inveja e gratidão e outros trabalhos (1946-1963); tradução da $4^{\text {a }}$ edição inglesa Belinda H. Mandelbaum et 
al. Rio de Janeiro: Imago, 1991.

LUKÁCS, George. A teoria do romance: um ensaio histórico-filosófico sobre as formas da grande épica; tradução, posfácio e notas José Marcos Mariani de Macedo. São Paulo: Duas Cidades; Editora 34, 2000. MORETTI, Franco. II romanzo. Torino: Giulio Einaudi Editore. 1950.

POUILLON, Jean. O tempo no romance; tradução Heloysa de Lima Dantas. São Paulo: Cultrix, 1974.

RAMOS, Maria Celeste Tommasello. A representação em Memórias póstumas de Brás Cubas e A consciência de Zeno. São José do Rio Preto: 2001. Tese (Doutorado em Letras/ Área de Teoria da Literatura). IBILCE - Instituto de Biociências Letras e Ciências Exatas - UNESP Universidade Estadual Paulista “Júlio de Mesquita Filho".

\section{IV - Websites de Referência}

All paintings. Disponível em:

$<$ http://www.allpaintings.org/v/Expressionism/Edvard+Munch/Edvard+Munch++Jealousy+1907.jpg.html>. Acesso em 10 julho 2014.

Galerie delle opere. Disponível em:

$<h t t p: / / w w w . i t a l i c a . r a i . i t / s c h e d a . p h p ? s c h e d a=b o r g h e s i a \_s p e c c h i o \_4>$. Acesso em 15 junho 2014. 
II matrimonio è in scena, di Oretta Guidi. Disponível em: <http://www.repubblicaletteraria.it/ltaloSvevo.html>. Acesso em 10 junho 2014.

Trieste tra immagini e storia. Disponível em: <http://www.carbonaio.it/immagini\%20trieste.htm>. Acesso em 15 junho 2014. 